\title{
QUATERNARY MORPHOLOGY AND PALEOENVIRONMENTAL RECORDS OF CARBONATE ISLANDS
}

\author{
By \\ Michael Toomey \\ B.A., Pomona College, 2008 \\ Submitted in partial fulfillment of the requirements for the degree of \\ Doctor of Philosophy \\ at the \\ MASSACHUSETTS INSTITUTE OF TECHNOLOGY \\ and the \\ WOODS HOLE OCEANOGRAPHIC INSTITUTION \\ February 2014 \\ (C) 2014 Michael Toomey \\ All rights reserved
}

The author hereby grants to MIT and WHOI permission to reproduce and to distribute publicly paper and electronic copies of this thesis document in whole or in part in any medium now known or hereafter created.

Signature of Author

Joint Program in Marine Geology \& Geophysics

Massachusetts Institute of Technology and Woods Hole Oceanographic Institution

October 22, 2013

Certified by

Dr. Jeffrey Donnelly

Thesis Supervisor

Accepted by

Dr. Timothy Grove Chair, Joint Committee for Marine Geology \& Geophysics Massachusetts Institute of Technology and Woods Hole Oceanographic Institution 


\title{
QUATERNARY MORPHOLOGY AND PALEOENVIRONMENTAL RECORDS OF CARBONATE ISLANDS
}

\author{
by \\ Michael Toomey \\ Submitted to the Massachusetts Institute of Technology and Woods Hole Oceanographic \\ Institution Joint Program in Oceanography on October 22, 2013 in partial fulfillment \\ of the requirements for the degree of Doctor of Philosophy in Marine Geology and \\ Geophysics
}

\begin{abstract}
Here I use a simple numerical model of reef profile evolution to show that the presentday morphology of carbonate islands has developed largely in response to late Pleistocene sea level oscillations in addition to variable vertical motion and reef accretion rates. In particular, large amplitude 'ice-house' sea-level variability resulted in long lagoonal depositional hiatuses, producing the morphology characteristic of modern-day barrier reefs. Reactivation of carbonate factories, transport of coarse reef material and rapid infilling of shallow water accommodation space since deglaciation makes these unique sites for reconstructing Holocene climate.

Integration of new tropical cyclone reconstructions from both backbarrier reef (central Pacific) and carbonate bank (the Bahamas) settings with existing storm archives suggests a coordinated pattern of cyclone activity across storm basins since the late Holocene. Seesawing of intense tropical cyclone activity between the western Pacific $(\sim 0-1000$ yrs BP) and North Atlantic/Central Pacific ( 1000-2500 yrs BP) appears closely tied with hydrographic patterns in the tropical Pacific and El Niño-like variability. Decoupling of North Atlantic (inactive) and South Pacific (active) tropical cyclone patterns during the mid-Holocene suggests precession driven changes in storm season insolation may constrain ocean-atmosphere thermal gradients and therefore cyclone potential intensity on orbital timescales.
\end{abstract}

Thesis Supervisor: Dr. Jeffrey P. Donnelly

Title: $\quad$ Associate Scientist, Department of Geology and Geophysics

Woods Hole Oceanographic Institution 


\section{ACKNOWLEDGEMENTS}

First and foremost I would like to thank my advisor Jeff Donnelly for his help and encouragement since I first showed up at WHOI as a visiting student many years ago. Likewise, I would like to thank Jon Woodruff who guided me through my first summer of research at WHOI and continues to be a mentor and a friend. Altogether, I cannot emphasize enough how lucky I feel to have been part of the Coastal Systems Group and work with so many smart and engaging people. In particular, I would like to acknowledge Stephanie Madsen, Richard Sullivan, Andrea Hawkes, Phil Lane and Pete van Hengstum for their help with fieldwork and in the lab. I would also like thank the members of my committee, Taylor Perron, Rob Evans, Bill Curry, Delia Oppo and Andrew Ashton for helping me through some of the greatest challenges of being a graduate student: submitting my first paper, designing new projects and my general exam. This is of course in addition to the thanks for all the thoughtful comments and conversations we've had about my thesis and more than a few projects still to come. Lastly, I would like to thank all my friends and family. In particular, the past five years would have been immeasurably more difficult without the support and kindness of Chris, Sandy, and Bridget. Dan Ohnemus, Abby Heithoff and Liz Bonk have been the best roommates and friends I could have asked for! During my time at WHOI I was funded by the Ocean and Climate Change Institute, a MIT Presidential fellowship, SERDP and the WHOI Academic Programs Office. 


\section{TABLE OF CONTENTS}

Abstract.................................................................

Acknowledgements.........................................................4

Chapter 1. Introduction................................................

Chapter 2. Profiles of ocean island coral reefs controlled by sea-level history and carbonate accumulation rates................................... 12

Chapter 3. Reconstructing mid-late Holocene cyclone variability in the Central Pacific using sedimentary records from Tahaa, French Polynesia........17

Chapter 4. Coupled hydrographic and tropical cyclone variability in the central South Pacific over the late-Holocene...................................27

Chapter 5. Reconstructing 7000 years of North Atlantic hurricane variability using deep-sea sediment cores from the western Great Bahama Bank...........40

\section{APPENDICES}

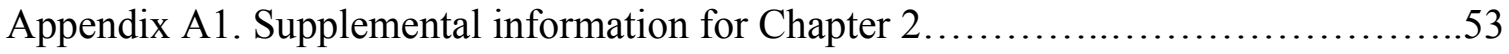

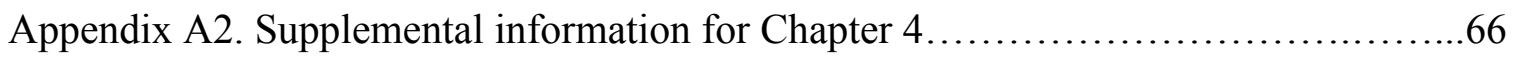




\section{CHAPTER 1: Introduction}

Contemporary climate change and increased storm frequency pose a unique threat to coastal communities, particularly those on low-lying tropical islands. However, significant risk uncertainty related to the intensification of tropical cyclone activity in a warming world remains. A lack of available storm records that both extend back deep in time and are widely spatially distributed has limited our ability to understand how hypothesized forcings (e.g. solar variability (Cohen and Sweetser, 1975), sea surface temperatures (Emanuel, 2005; Webster et al., 2005), volcanic aerosols (Elsner and Kara, 1999), the West African Monsoon (Bell and Chelliah, 2006), Atlantic multi-decadal oscillation (Goldenberg et al., 2001) have controlled tropical cyclone activity in the geologic past and project how they may in the future.

In particular, analysis of instrumental records (e.g. Gray, 1984; Revell and Goulter, 1986) and existing reconstructions (e.g. Donnelly and Woodruff, 2007; Woodruff et al., 2009) suggest ENSO may be a key driver of past tropical cyclone variability but several obstacles exist in quantifying this relationship on geologic timescales and ruling out alternative forcing mechanisms: (1) existing reconstructions show variable ENSO behavior over the Holocene and are located outside storm basins, (2) age model uncertainty ( $\sim 50-100 \mathrm{yrs})$ limits characterization of high frequency ENSO-TC interaction, (3) conventional sites (e.g. coastal back-barrier marshes and ponds) typically formed following sea-level stabilization during the late Holocene and (4) and are scarce in the tropics. Carbonate environments (e.g. barrier reefs, platforms) may offer long, continuous records of cyclone activity, ENSO, sea level and are widespread in the tropics but have been largely overlooked.

In turn, field and modeling evidence (e.g. Le Roy et al., 2008; Paulay and McEdward, 1990) suggest climate has exerted significant control on the morphology of carbonate islands themselves and understanding how carbonate depositional environments form is 
key to interpreting their paleo-history. Refining both our conceptual and modeling frameworks for the evolution of reef morphology over glacial-interglacial timescales is also a critical first step in mitigating contemporary sea-level rise on many tropical islands. Even a modest rise in sea level may devastate many atoll nations and increase their sensitivity extreme events.

Main Objectives: Here I use a numerical model of reef development and target specific sedimentary archives from French Polynesia and the Bahamas to address the following questions:

1. What are the main factors that have led to the differentiation of reef types and how have depositional environments on carbonate islands developed over glacialinterglacial timescales?

2. How has tropical cyclone activity varied over the Holocene?

3. Are there geographic patterns in Holocene cyclone activity (Basin to basin or at the sub-basin scale)?

4. What is the relationship between storminess and other climate systems (e.g. ENSO, West African Monsoon, Insolation, SST)?

Chapter 2: Profiles of ocean island coral reefs controlled by sea-level history and carbonate accumulation rates

Much controversy has surrounded Darwin's canonical model of atoll development driven by island subsidence, which overlooks the role of Pleistocene sea-level oscillations in driving development of reef morphology. In chapter two I use a numerical model of reef development to understand the role of sea-level oscillations over the past $400 \mathrm{kyrs}$, and compare the results with a new dataset of coral growth and island vertical motion based on a survey of available literature sources. I find that sea-level oscillations are key in 
explaining the modern real-world distribution of reef forms and that Darwin's 'Subsidence-Control' theory only applies to a small subset of islands.

Chapter 3: Reconstructing mid-late Holocene cyclone variability in the Central Pacific using sedimentary records from Tahaa, French Polynesia

In chapter three I present the first continuous tropical cyclone reconstruction to date from the Central Pacific and address several fundamental questions about which climatic forcings drive changes in tropical cyclone activity worldwide. Many questions remain regarding how tropical cyclone activity will change in response to ongoing anthropogenic climate change and which factors have influenced storm activity in the geologic past. These disputes stem from: (1) a scarcity of available tropical cyclone reconstructions from locations other than the western North Atlantic, and (2) a shortage of records that extend back deep in time. This reconstruction is the first to use barrier-reef lagoon sediments to develop a long-term record of storm impacts and provides a template for developing tropical cyclone records throughout the Pacific, an area that has so far been overlooked due to a lack of conventional backbarrier wetland and lake sites. These records are necessary for calibrating models of how tropical cyclone activity will be impacted by ongoing anthropogenic warming and assessing the risk of coastal communities, particularly on low-lying atolls, to future extreme events.

Chapter 4: Coupled hydrographic and tropical cyclone variability in the central South Pacific over the late-Holocene

Instrumental records suggest the El Niño-Southern Oscillation (ENSO) coordinates tropical cyclone activity across the Pacific, but longer and more geographically diverse records are necessary to test this relationship over geologic timescales. Here I develop the first continuous, multi-millennial record of central Pacific hydro-climate based on runoff deposition in a sediment core from Apu Bay on the island of Tahaa, French Polynesia. 
These data suggest that there has been a gradual increase in precipitation across the tropical South Pacific over the late Holocene. I also present evidence of a negative correlation between tropical cyclone driven overwash deposits in the same core and observed changes in hydroclimate, representing the first attempt to statistically compare these proxies on geologic timescales. Observed environmental changes also coincide closely with the timing of human migration into the central Pacific suggesting that an increase in ENSO driven wind reversals may have been key element of Polynesian expansion.

Chapter 5: Reconstructing 7000 years of North Atlantic hurricane variability using deepsea sediment cores from the western Great Bahama Bank

Here I present a new proxy for reconstructing past hurricane activity using carbonate bank turbidite deposits, develop the longest continuous cyclone record to date and address several fundamental questions about which climatic forcings drive long-term changes in hurricane activity. This new proxy uses coarse carbonate bank flank deposits as a proxy for past hurricane activity and provides a blueprint for readily extending our knowledge of hurricane activity to at least $6000 \mathrm{yrs}$ BP. The Bahamas record suggests hurricane frequency in the North Atlantic may have been substantially lower during the mid-Holocene. One explanation for this pattern is that higher mid-Holocene storm season insolation due to precession diminished ocean-atmosphere thermal gradients in the North Atlantic limiting hurricane potential intensity.

References:

Bell, G.D., Chelliah, M., 2006. Leading Tropical Modes Associated with Interannual and Multidecadal Fluctuations in North Atlantic Hurricane Activity. Journal of Climate 19, 590-612. 
Cohen, T.J., Sweetser, E.I., 1975. The 'spectra' of the solar cycle and of data for Atlantic tropical cyclones. Nature 256, 295-296.

Donnelly, J.P., Woodruff, J.D., 2007. Intense hurricane activity over the past 5,000 years controlled by El Nino and the West African monsoon. Nature 447, 465-468.

Elsner, J.B., Kara, A.B., 1999. Hurricanes of the North Atlantic. Oxford University Press, New York.

Emanuel, K., 2005. Increasing destructiveness of tropical cyclones over the past 30 years. Nature 436, 686-688.

Goldenberg, S.B., Landsea, C.W., Mestas-Nuñez, A.M., Gray, W.M., 2001. The Recent Increase in Atlantic Hurricane Activity: Causes and Implications. Science 293, 474-479.

Gray, W.M., 1984. Atlantic Seasonal Hurricane Frequency. Part I: El Niño and 30 mb Quasi-Biennial Oscillation Influences. Monthly Weather Review 112, 1649-1668.

Le Roy, P., Cabioch, G., Monod, B., Lagabrielle, Y., Pelletier, B., Flamand, B., 2008. Late Quaternary history of the Nouméa lagoon (New Caledonia, South West Pacific) as depicted by seismic stratigraphy and multibeam bathymetry: A modern model of tropical rimmed shelf. Palaeogeography, Palaeoclimatology, Palaeoecology 270, 29-45.

Paulay, G., McEdward, L.R., 1990. A simulation model of island reef morphology: the effects of sea level fluctuations, growth, subsidence and erosion. Coral Reefs 9, 51-62.

Revell, C.G., Goulter, S.W., 1986. South Pacific tropical cyclones and the Southern Oscillation. Mon. Weath. Rev 114, 1138-1145. 
Webster, P.J., Holland, G.J., Curry, J.A., Chang, H.-R., 2005. Changes in Tropical Cyclone Number, Duration, and Intensity in a Warming Environment. Science 309, 1844-1846.

Woodruff, J.D., Donnelly, J.P., Okusu, A., 2009. Exploring typhoon variability over the mid-to-late Holocene: evidence of extreme coastal flooding from Kamikoshiki, Japan. Quaternary Science Reviews 28, 1774-1785. 


\title{
CHAPTER 2: Profiles of ocean island coral reefs controlled by sea-level history and carbonate accumulation rates*
}

\begin{abstract}
Modern and preserved coral reefs on islands exhibit a broad range of forms, from actively accreting fringing and barrier reefs to terraces preserved by drowning or subaerial exposure. Darwin's canonical model of reef development proposes an evolutionary sequence of reef forms as a volcanic island ages and subsides, from fringing reef to lagoon-bounding barrier reef to atoll. Compiled data from modern systems show, however, that many islands do not follow this sequence, implying that reefs are shaped by more than island subsidence alone. We show that the diversity of modern reef morphology arises from the combined effects of island subsidence, coral growth, and glacial sea-level cycles. A model for the evolution of a reef elevation profile over the past 400 k.y. reveals that different combinations of reef accretion rate and island vertical motion produce a variety of forms that matches the observed distribution of modern reefs. This match occurs only if the model is driven by Pleistocene sea-level oscillations - few modern environments have the right combination of conditions to produce the Darwinian atoll progression.
\end{abstract}

*Published as: Toomey, M., A.D. Ashton and J.T. Perron (2013). Profiles of ocean island coral reefs controlled by sea-level history and carbonate accumulation rates, Geology, 41, 731-734, doi:10.1130/G34109.1. Supplemental for this paper is contained in Appendix 1.

Reproduced with permission from GSA. 


\title{
Profiles of ocean island coral reefs controlled by sea-level history and carbonate accumulation rates
}

\author{
Michael Toomey ${ }^{1,2 *}$, Andrew D. Ashton ${ }^{1}$, and J. Taylor Perron ${ }^{2}$ \\ ${ }^{1}$ Geology and Geophysics Department, Woods Hole Oceanographic Institution, 360 Woods Hole Road, MS\#22, Woods Hole, \\ Massachusetts 02543, USA \\ 2Department of Earth, Atmospheric, and Planetary Sciences, Massachusetts Institute of Technology, Cambridge, Massachusetts \\ 02139, USA
}

\section{ABSTRACT}

Modern and preserved coral reefs on islands exhibit a broad range of forms, from actively accreting fringing and barrier reefs to terraces preserved by drowning or subaerial exposure. Darwin's canonical model of reef development proposes an evolutionary sequence of reef forms as a volcanic island ages and subsides, from fringing reef to lagoon-bounding barrier reef to atoll. Compiled data from modern systems show, however, that many islands do not follow this sequence, implying that reefs are shaped by more than island subsidence alone. We show that the diversity of modern reef morphology arises from the combined effects of island subsidence, coral growth, and glacial sea-level cycles. A model for the evolution of a reef elevation profile over the past 400 k.y. reveals that different combinations of reef accretion rate and island vertical motion produce a variety of forms that matches the observed distribution of modern reefs. This match occurs only if the model is driven by Pleistocene sea-level oscillations-few modern environments have the right combination of conditions to produce the Darwinian atoll progression.

\section{INTRODUCTION}

Coral reefs dynamically adapt to vertical motion (uplift or subsidence), erosion, antecedent topography, and changing sea level, developing a variety of profile forms (Fig. 1) (Montaggioni, 2005). Following the recognition of Pleistocene sea-level oscillations, Daly (1910) challenged Darwin's (1842) subsidence model, insisting that wave erosion of volcanic islands during sea-level lowstands produces the needed vertical accommodation for reef growth. Drill cores from Eniwetok Atoll in the Pacific Ocean (Ladd et al., 1953) eventually supported Darwin's suggestion that island subsidence with age plays a major role in reef development. A survey of morphologic types (Table DR1 in the GSA Data Repository'), however, reveals that a wide variety of reef forms found in modern systems (in particular uplifted terraces and drowned barrier reefs) cannot be explained by Darwin's subsidence model alone. For example, subsidence control is consistent with the progression of reef types with increasing island age and subsidence in the Society Islands (South Pacific, Figs. 1D-1G), but cannot explain the variety of reefs found in the Hawaiian Islands (North Pacific, Figs. 1A-1C).

Many previous studies have introduced numerical models of reef profile development (Bosence and Waltham, 1990; Bosscher and Schlager, 1992; Chappell, 1980; Hill et al.,

\footnotetext{
*E-mail: mrt02008@mit.edu.

'GSA Data Repository item 2013204, Table DR1 and Videos DR1-DR6 (showing development of each script), is available online at www.geosociety.org/pubs $/ \mathrm{ft} 2013$.htm, or on request from editing@geosociety .org or Documents Secretary, GSA, P.O. Box 9140, Boulder, CO 80301, USA.
}

2009; Koelling et al., 2009; Paterson et al., 2006; Paulay and McEdward, 1990; Warrlich et al., 2002; Webster et al., 2007). In general, these models have related reef morphology at specific sites to rates of island subsidence, reef accretion, and sea-level rise, but do not satisfactorily explain the wide range of morphologic variability observed in modern reefs.

Here we address the broad-scale controls on island reef form. First, we discuss the growth and stability of reefs as they experience island vertical motion and sea-level change. Second, we implement a profile model of long-term reef development, systematically exploring reef evolution for a wide variety of vertical motion rates, reef accretion rates, and sea-level histories over glacial sea-level cycles. Finally, we compare the gross morphology of reef profile forms generated by the model with those of natural reefs with known vertical motion and accretion rates.

\section{CORAL GROWTH AND SEA LEVEL}

The primary control on the development of coral reefs over the time scales of glacial

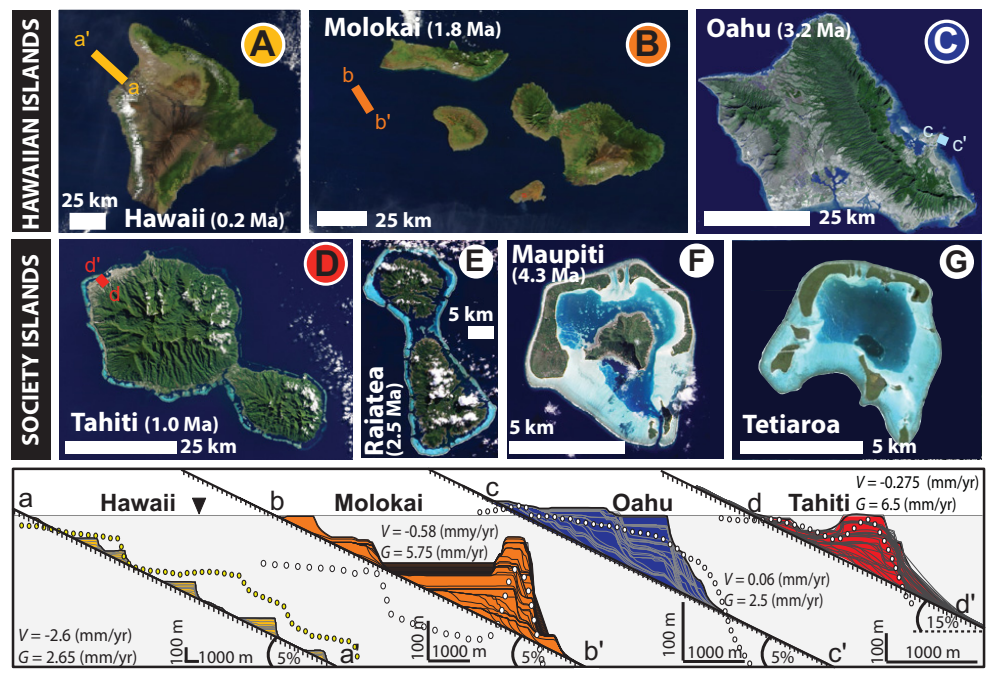

Figure 1. Variations in reef surface and profile morphology across two island chains. In the Hawaiian Islands $(A-C)$, modern, fringing reefs are active at sea level, but bathymetric profiles (bottom) reveal a series of older, drowned reef terraces near the Big Island of Hawaii and a drowned barrier reef near Molokai. D-G: Reef morphology in the Society Islands progresses with age and cumulative subsidence from fringing reef to barrier reef to atoll as predicted by Darwin's (1842) model. Known island ages increase to the right (Dasgupta et al., 2010). The age of Tetiaroa, with its submerged volcanic edifice, remains unknown. Bottom: Modern reef bathymetry (dotted line) compared with model profiles derived using reported coral growth $\left(G_{\max }\right)$, vertical motion rates $(V$; Table DR1 in the Data Repository [see footnote $1]$ ), and initial island gradient (\% grade). Solid lines show model profiles at 10 k.y. intervals. Images and data from Google Earth ${ }^{\mathrm{TM}}$, NASA, and GeoMapApp ${ }^{\odot}$ (www.geomapapp.org). 
cycles is the vertical rate of reef accretion, the integrated effect of coral growth, local production of detritus, and lithification (Montaggioni, 2005). Several expressions for reef accretion rate have been proposed (Williams et al., 2011), but most take a form similar to that proposed by Bosscher and Schlager (1992), in which coral growth rate, and thus reef accretion rate, is a decreasing function of water depth (a proxy for reduced light intensity, which limits photosynthesis by coral's symbiotic algae) (Fig. 2; Equation DR5 in the Data Repository).

For a given constant rate of long-term relative sea-level rise, this relationship yields two fixed points where the rate of reef accretion matches the submergence rate, one shallow and stable, the other deep and unstable (Fig. 2) (Kim et al., 2012). The unstable equilibrium point represents the drowning depth. At deeper depths, sea-level rise outpaces reef accretion, progressively drowning and abandoning the reef. Reefs beginning at depths shallower than the drowning depth can grow faster than sea-level rise, and consequently will rise toward the stable equilibrium near the surface, eventually reaching a balance between relative sea-level rise and accretion.

The diagram in Figure 2 relates these feedbacks to the "keep-up," "catch-up," and "giveup" behavior often used to describe deglacial reef growth (Neuman and Macintyre, 1985). Reefs can "keep up" with slow to moderate rates of relative sea-level rise ( $\leq$ maximum accretion rates), growing toward the stable fixed point close to the surface (Kim et al., 2012). During deglaciations, however, rates of sea-level rise (>25 mm/yr) can significantly outpace maximum reef accretion rates (typically $<10 \mathrm{~mm} / \mathrm{yr}$ ), potentially submerging the reef. Once sea-level

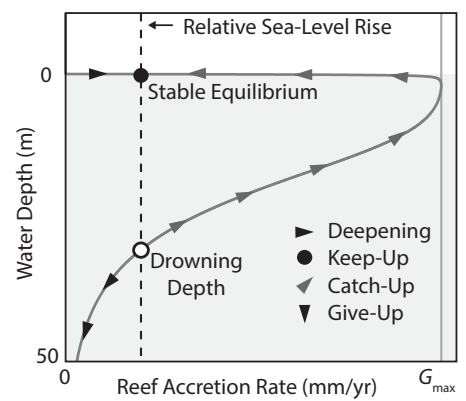

Figure 2. Phase-space plot of coral reef accumulation. Reef accretion rate declines with increasing water depth due to light attenuincreasing water depth due to light attenu-
ation (Equation DR5 in the Data Repository ation (Equation DR5 in the Data Repository
[see footnote 1]). For a given rate of relative sea-level rise (dashed line), reef accretion exactly matches submergence, defining stable (solid circle) and unstable (open circle) equilibrium depths. Arrows along the curve show phase-space trajectories. rise slows, two scenarios are possible: either the reef has remained shallower than the drowning depth and "catches up" to the stable equilibrium depth, or the reef is submerged sufficiently deeply that it "gives up," at least until sea level falls again.

\section{REEF MODEL}

To better understand how sea-level variability and coral growth interact, we developed a profile model of reef growth similar to other models that have been presented in the literature (Bosence and Waltham, 1990; Bosscher and Schlager, 1992; Paulay and McEdward, 1990; Webster et al., 2007). Although more complicated models have been developed that incorporate many different processes and components, including community composition, facies classification, local currents, and supersaturation (Hill et al., 2009; Paterson et al., 2006; Warrlich et al., 2002), the complexity of these models can complicate the connection between reef form and driving forces. Our approach of using an exploratory model allows us to test, across a wide swath of parameter space, whether a simpler set of processes is sufficient to capture the essential dynamics of reef evolution and explain the observed variety of reef forms.

The model computes changes in surface elevation with time and distance as a function of subsidence or uplift of the island, reef accretion, wave erosion, and sediment deposition (Fig. DR1). The main components of the model are summarized below, and detailed methods can be found in the Data Repository. The model consists of an elevation profile of the subaerial and submerged island flank with a linear initial slope (Fig. 1; Fig. DR1). The island experiences a temporally and spatially constant rate of vertical motion due to uplift or subsidence $(V, \mathrm{~mm} / \mathrm{yr}$, uplift is positive) as well as a prescribed sea-level time series (constant, proxy-based, or 100 k.y. sawtooth). Reef accretion rate depends on water depth (Fig. 2; Equation DR5) (Bosscher and Schlager, 1992), and we vary the maximum rate of reef accretion $\left(G_{\max }, \mathrm{mm} / \mathrm{yr}\right)$ among simulations to represent different growth environments (Montaggioni, 2005). Reef accretion is maximized proximal to the open ocean, representing how ocean waves both foster coral growth in natural reefs and attenuate within $\sim 100-500 \mathrm{~m}$ lagoonward of the reef crest (Kench and Brander, 2006). Similar to other models (Bosence and Waltham, 1990; Paterson et al., 2006; Warrlich et al., 2002), we limit accumulation to a region $200 \mathrm{~m}$ lagoonward of the reef crest (defined as the location where the reef becomes shallower than $2 \mathrm{~m}$ ). Wave erosion (and rock weathering) tends to be focused in the surf and intertidal zones (Trenhaile, 2001). Accordingly, the model erodes the exposed reef crest to a depth of $2 \mathrm{~m}$ at a constant rate of $2 \mathrm{~mm} / \mathrm{yr}$ within $200 \mathrm{~m}$ of the open ocean.
If a lagoon is present, sediment produced by wave erosion accumulates in the lagoon; otherwise, sediment accumulates offshore on the reef front at the angle of repose. Lagoon sediment is also generated by primary production of carbonate in the water column; here we use a constant rate of $0.2 \mathrm{~mm} / \mathrm{yr}$, consistent with field observations (Zinke et al., 2001).

We run the model for 400 k.y., which allows antecedent topography to develop dynamically over four glacial cycles. This timescale represents the limit of most proxy sea-level records (e.g., Waelbroeck et al., 2002), and is shorter than the timescale over which vertical motion rates of ocean islands change due to isostatic compensation and crustal cooling ( $\sim 1$ m.y.) (Watts and Zhong, 2000).

\section{SURVEY OF MODERN REEF \\ CHARACTERISTICS}

To demonstrate the diversity of modern reef settings, and to provide a basis for testing the reef model, we compiled a data set of natural reefs for which vertical motion and coral accretion rates are known (Table DR1). This data set permits two observational tests of the model: a comparison of the overall distribution of reef types with respect to geologic conditions, and comparisons of individual reef profiles with modeled profiles.

\section{RESULTS AND DISCUSSION}

For each sea-level scenario, we ran 10,000 simulations spanning different vertical motion and maximum reef accretion rates, and classified the final surface profiles into six basic morphologic types (Fig. 3): fringing reefs, drowned terraces, barrier reefs, drowned barrier reefs, emergent fringing reefs, and uplifted terraces.

For a hypothetical stable sea level over the last 400 k.y. (Fig. 3A), the distribution of reef types largely follows the expectations derived from the phase-space plot (Fig. 2). The shift from barrier reefs to single drowned terraces at faster subsidence rates and slower accretion rates represents the boundary between keep-up or catch-up reefs and those that are "drowning" (although even in the drowning case, coral growth occurs along the coast and translates upslope as the island subsides). The transition from barrier to fringing reefs occurs at slow subsidence rates $(-0.7<V<0 \mathrm{~mm} / \mathrm{yr})$, for which lagoon sedimentation keeps pace with the creation of back-reef accommodation depth by subsidence. Under uplifting conditions and constant sea level, emergent fringing reefs can form in two ways: (1) fast reef accretion rates ( $>7 \mathrm{~mm} / \mathrm{yr}$ ) lead to rapid formation of a fringing reef, which is then quickly uplifted before it can be destroyed by wave erosion; or (2) creation of emergent fringing reefs $(0<V<0.25 \mathrm{~mm} / \mathrm{yr})$ occurs gradually as the reef is uplifted, creating a shallowly dipping platform near sea level. 

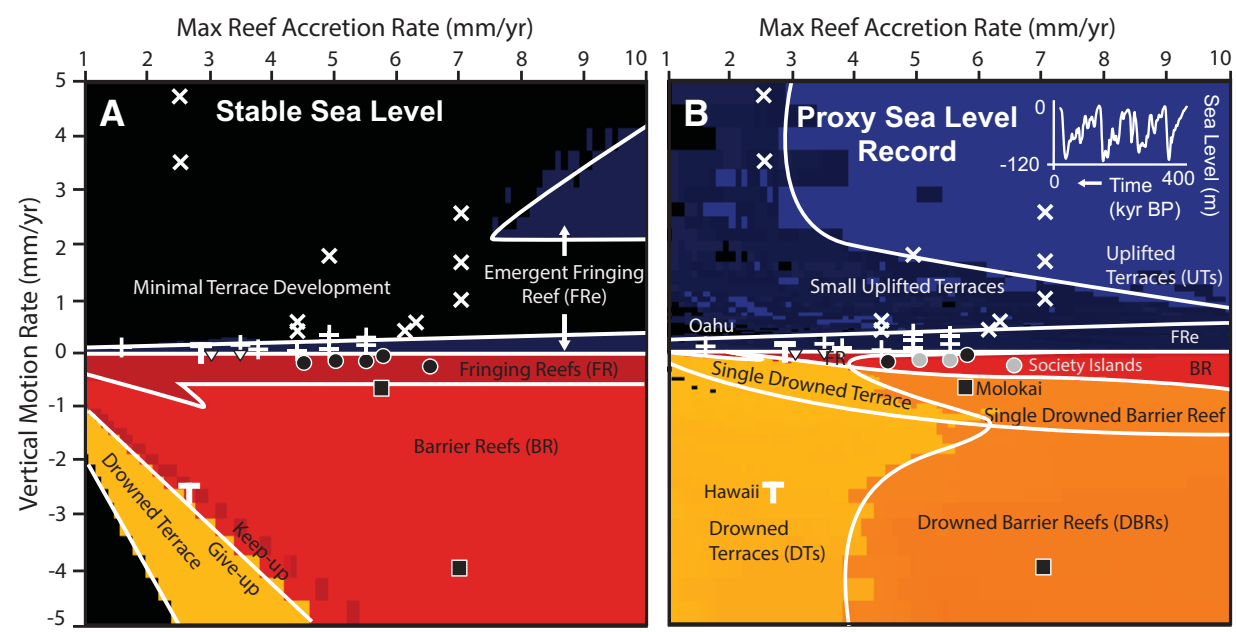

Model Real World

Reefs Reefs UTS Uplifted

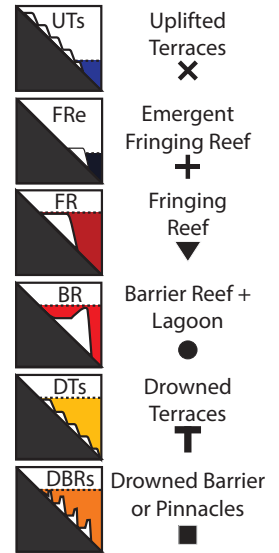

Figure 3. Regime diagrams characterizing reef morphology derived from models driven by constant absolute sea level (A) and oscillating sea level (B) from a proxy-derived record (Waelbroeck et al., 2002). Six main reef types were identified based on their morphology (see the Data Repository for classification procedure): uplifted terraces (UTs), emergent fringing reef (FRe), fringing reef (FR), barrier reef (BR), drowned terraces (DTs), and drowned barrier reefs (DBRs). White lines represent the smoothed approximations of the boundaries between each reef type. In black areas, there is minimal morphological reef development due to slow growth or wave erosion. Real-world reef data points are derived from Table DR1 in the Data Repository [see footnote 1].

When the model is driven by a late Pleistocene proxy-derived sea-level curve (Fig. 3B, inset), a very different distribution of reef types develops (Fig. 3B). In general, reef drowning is more likely, fringing reefs are suppressed, and terraces develop on uplifting and rapidly subsiding islands.

With sea-level oscillations, drowned flights of terraces and barrier reefs occur under conditions of rapid subsidence $(V<-1 \mathrm{~mm} / \mathrm{yr})$. Similar to examples from Hawaii and the Huon Gulf (Webster et al., 2009), these abandoned reefs generally initiate during highstands, develop a lagoon or platform (depending on the growth rate) during the ensuing glacial regression as cumulative subsidence matches or exceeds sea-level fall, then are drowned by rapid deglaciation. Before sea level returns to its glacial minimum, rapid subsidence carries the reef well below the giveup depth of the successive lowstand, preventing reactivation

Under more moderate rates of subsidence ( -1 $<V<-0.4 \mathrm{~mm} / \mathrm{yr}$ ), a single drowned lagoon or terrace develops (e.g., Molokai). These features do not necessarily correspond directly to highstands or lowstands, but rather tend to form as the reef is drowned during deglaciation. Reefs experiencing moderate subsidence rates may be only temporarily drowned, however, and can grow significantly as sea level slowly lowers after a highstand.

Barrier reefs ( $>10 \mathrm{~m}$ deep lagoon; e.g., Tahiti) and fringing reefs (e.g., Réunion, Indian Ocean) are principally highstand features that develop when slow to moderate subsidence rates $(-0.4<V<-0.05 \mathrm{~mm} / \mathrm{yr})$ create accommodation depths encouraging growth. Typically, lagoons form if the maximum growth rate is moderate to fast $\left(G_{\max }>4 \mathrm{~mm} / \mathrm{yr}\right)$ and the reef is able to keep up with sea-level rise during deglaciations. Fringing reefs can develop in two ways: (1) slow subsidence limits creation of vertical accommodation in the lagoon and it fills up with sediment, creating a platform; or (2) a wide platform, originally deeper than $2 \mathrm{~m}$, follows a catch-up trajectory, with landward growth stopping when the reef front reaches $2 \mathrm{~m}$ depth.

In the case of uplifting systems, multiple wide terraces ( $>200 \mathrm{~m}$ wide; e.g., the Huon Peninsula) form with rapid uplift rates $(V>1 \mathrm{~mm} /$ yr) as successive highstand reefs are stranded subaerially. Rapid uplift promotes wide terraces by raising deeper portions of the slope into the catch-up zone during each highstand. Moderate uplift rates result in narrower terraces with widths commensurate with the imposed growth width $(\sim 200 \mathrm{~m})$. At very slow uplift rates, one or two wide terraces develop relatively close to sea level (emergent fringing reefs; e.g., Oahu). In this case, wave erosion limits terrace development; otherwise, wave erosion does not have a major impact on model outcomes.

The regime diagram of characteristic reef types for Pleistocene sea-level oscillations (Fig. 3B) contrasts sharply with the one derived using a stable sea-level curve (Fig. 3A). First, sea-level oscillations result in the formation of uplifted and drowned flights of terraces, features similar to those noted in the literature (e.g., Webster et al., 2009) but conspicuously absent in models run with a stable sea level. Drowned reefs, including single and multiple features, are much more likely with sea-level oscillations, as reefs are abandoned by rapid sea-level rise during deglaciations. Another key difference is the reduced abundance of fringing reefs with variable sea level. Given that observed rates of lagoon sedimentation $(>1 \mathrm{~mm} / \mathrm{yr}$ ) are often considerably faster than subsidence rates $(<0.5 \mathrm{~mm} / \mathrm{yr})$ for most islands, depositional hiatuses during sea-level oscillations appear to be essential in preventing lagoons from filling completely, encouraging the proliferation of barrier reefs (rather than wide fringing reefs) in the modern world.

Based on estimates of vertical motion and maximum growth rates from modern environments (Table DR1), the forms of natural reefs in our database are more consistent with the regime diagram generated by sea-level oscillations (Fig. 3B) than the model with stable sea level (Fig. 3A). Perhaps the most significant difference is that most islands with barrier reefs occupy the zone where fringing reefs are predicted if sea level is constant. Using a generic, sawtooth 100 k.y. sea-level cycle instead of the isotope-derived sea-level curve demonstrates that the primary control on reef type is, indeed, sea-level oscillations, and that multiple oscillations foster the formation of barrier reefs (Figs. DR2 and DR3).

Bathymetric profiles from islands in various geographic settings can also be compared with model runs using similar rates of vertical motion, reef accretion, and proxy sea-level curve 
(Fig. 1). Our simplified model is not intended to simulate the evolution of any one specific natural reef, but it does permit a general comparison of reef forms. For rates similar to those of Tahiti, the model generates a lagoon with depth and width similar to those observed in bathymetric profiles (Fig. 1D). The model is also able to capture the trend in gross morphology of reef profiles with increasing age (and therefore different rates of vertical motion) across the Hawaiian Islands (Figs. 1A-1C). In contrast, running the model with a stable sea level only generates the correct reef type for Oahu (Fig. 3).

Why do the Society Islands follow Darwin's progression but the Hawaiian Islands do not? Our results suggest that subsidence and accretion rates in the Society Islands happen to fall within a narrow range that favors the formation of barrier reefs when islands experience $\sim 100$ k.y. sea-level oscillations. Within the broader parameter space of uplift and growth rates (Fig. 3), this "Goldilocks zone" for barrier reef formation is quite limited. Reef development on the many islands that fall outside this zone, such as the Hawaiian Islands, with their slow growth rates and faster and more varied vertical motion rates, is unlikely to follow Darwin's (1842) conceptual model for atoll formation.

\section{CONCLUSIONS}

A simple numerical model incorporating coral growth, wave erosion, and uplift or subsidence can generate much of the variability observed in elevation profiles across natural reefs. In a sense, these results reconcile Daly (1910) with Darwin (1842): reef profiles and the formation of barrier reefs are controlled by subsidence and vertical coral growth and accumulation, yet the morphology of modern reefs bears the strong imprint of Pleistocene sea-level oscillations. On even longer timescales, variations in the frequency and magnitude of sea-level oscillations have likely created different global distributions of reef forms and atolls at different times in the geologic past.

\section{ACKNOWLEDGMENTS}

This research was supported by the Andrew W. Mellon Foundation and the Ralph E. Hall Endowed Funds for Innovative Research through WHOI. We thank Bill Thompson, Michael O'Leary, and Dan Rothman for their feedback, and Wonsuck Kim, Jody Webster, and two anonymous reviewers for their comments.

\section{REFERENCES CITED}

Bosence, D., and Waltham, D., 1990, Computer modeling the internal architecture of carbonate platforms: Geology, v. 18, p. 26-30, doi: 10.1130 0091-7613(1990)018<0026:CMTIAO > 2.3 $\mathrm{CO} ; 2$

Bosscher, H., and Schlager, W., 1992, Computer simulaion of reef growth: Sedimentology, v. 39, p. 503 512, doi:10.1111/j.1365-3091.1992.tb02130.x

Chappell, J., 1980, Coral morphology, diversity and reef growth: Nature, v. 286, p. 249-252, doi 10.1038/286249a0.

Daly, R.A., 1910, Pleistocene glaciation and the cora reef problem: American Journal of Science, v. 30 p. 297-308, doi:10.2475/ajs.s4-30.179.297.

Darwin, C.R., 1842, The structure and distribution of coral reefs, being the first part of the geology of the voyage of the Beagle, under the command of Capt. Fitzroy, R.N., during the years 1832 to 1836: London, Smith Elder and Co., 214 p.

Dasgupta, R., Jackson, M.G., and Lee, C.T.A., 2010, Major element chemistry of ocean isand basalts-Conditions of mantle melting and heterogeneity of mantle source: Earth and Planetary Science Letters, v. 289, p. 377-392, doi:10.1016/j.epsl.2009.11.027.

Hill, J., Tetzlaff, D., Curtis, A., and Wood, R., 2009, Modeling shallow marine carbonate depositional systems: Computers \& Geosciences, v. 35 p. 1862-1874, doi:10.1016/j.cageo.2008.12.006

Kench, P.S., and Brander, R.W., 2006, Wave processes on coral reef flats: Implications for ree geomorphology using Australian case studies: Journal of Coastal Research, v. 221, p. 209 223, doi:10.2112/05A-0016.1

Kim, W., Fouke, B.W., Petter, A.L., Quinn, T.M. Kerans, C., and Taylor, F., 2012, Sea-level rise, depth-dependent carbonate sedimentation and the paradox of drowned platforms: Sedimentol ogy, v. 59 , p. $1677-1694$, doi:10.1111/j.136 $-3091.2012 .01321 . x$

Koelling, M., Webster, J.M., Camoin, G., Iryu, Y., Bard, E., and Seard, C., 2009, SEALEX-Internal reef chronology and virtual drill logs from a spreadsheet-based reef growth model: Global and Planetary Change, v. 66, p. 149 159, doi:10.1016/j.gloplacha.2008.07.011.

Ladd, H.S., Ingerson, E., Russel, M., Stephenson, H.K., and Townsend, R.C., 1953, Drilling on Eniwetok atoll, Marshall islands: American Association of Petroleum Geologists Bulletin, v. 37 , p. $2257-2280$.

Montaggioni, L.F., 2005, History of Indo-Pacific coral reef systems since the last glaciation: Development patterns and controlling factors: Earth-Science Reviews, v. 71, p. 1-75, doi:10.1016/j.earscirev.2005.01.002.

Neuman, A.C., and Macintyre, I.G., 1985, Reef response to sea level rise: Keep-up, catch-up or give-up, in Gabrie, C., et al., eds., Proceedings of the Fifth International Coral Reef Congress, Tahiti, 27 May-1 June 1985, v. 3, p. 105-110.

Paterson, R.J., Whitaker, F.F., Jones, G.D., Smart, P.L., Waltham, D., and Felce, G., 2006, Ac- commodation and sedimentary architecture of isolated icehouse carbonate platforms: Insights from forward modeling with CARB3D+: Jour1182, doi:10.2110/jsr.2006.113.

Paulay, G., and McEdward, L.R., 1990, A simulation model of island reef morphology: The effects of sea level fluctuations, growth, subsidence and erosion: Coral Reefs, v. 9, p. 51-62, doi:10.1007/BF00368800

Trenhaile, A.S., 2001, Modeling the effect of late Quaternary interglacial sea levels on wave-cut shore platforms: Marine Geology, v. 172, p. 205-223, doi:10.1016/S0025-3227(00)00136-5.

Waelbroeck, C., Labeyrie, L., Michel, E., Duplessy, J.C., McManus, J.F., Lambeck, K., Balbon, E., and Labracherie, M., 2002, Sea-level and deep water temperature changes derived from benthic foraminifera isotopic records: Quaternary Science Reviews, v. 21 , p. 295-305, doi:10.1016/S0277-3791(01)00101-9.

Warrlich, G.M.D., Waltham, D.A., and Bosence, D.W.J., 2002, Quantifying the sequence stratigraphy and drowning mechanisms of atolls using a new 3-D forward stratigraphic modelling program (CARBONATE 3D): Basin Research, v. 14 , p. 379-400, doi:10.1046/j.1365 $-2117.2002 .00181 . x$.

Watts, A.B., and Zhong, S., 2000, Observations of flexure and the rheology of oceanic lithosphere: Geophysical Journal International, v. 142, p. 855875, doi:10.1046/j.1365-246x.2000.00189.x.

Webster, J.M., Wallace, L.M., Clague, D.A., and Braga, J.C., 2007, Numerical modeling of the growth and drowning of Hawaiian coral reefs during the last two glacial cycles $(0-250 \mathrm{kyr})$ : Geochemistry Geophysics Geosystems, v. 8, Q03011, doi:10.1029/2006GC001415.

Webster, J.M., Braga, J.C., Clague, D.A., Gallup, C., Hein, J.R., Potts, D.C., Renema, W., Riding, R., Riker-Coleman, K., and Silver, E., 2009, Coral reef evolution on rapidly subsiding margins: Global and Planetary Change, v. 66, p. 129148, doi:10.1016/j.gloplacha.2008.07.010.

Williams, H.D., Burgess, P.M., Wright, V.P., Della Porta, G., and Granjeon, D., 2011, Investigating carbonate platform types: Multiple controls and a continuum of geometries: Journal of Sedimentary Research, v. 81, p. 18-37, doi:10.2110 /jsr.2011.6.

Zinke, J., Reijmer, J.J.G., and Thomassin, B.A., 2001, Seismic architecture and sediment distribution within the Holocene barrier reef lagoon complex of Mayotte (Comoro archipelago, SW Indian Ocean): Palaeogeography, Palaeoclimatology, Palaeoecology, v. 175 , p. 343-368, doi:10.1016/S0031-0182(01)00379-0.

Manuscript received 7 October 2012

Revised manuscript received 24 January 2013

Manuscript accepted 26 January 2013

Printed in USA 


\section{CHAPTER 3: Reconstructing mid-late Holocene cyclone variability in the Central Pacific using sedimentary records from Tahaa, French Polynesia ${ }^{*}$}

\section{ABSTRACT}

We lack an understanding of the geographic and temporal controls on South Pacific cyclone activity. Overwash records from backbarrier salt marshes and coastal ponds have been used to reconstruct tropical cyclone strikes in the North Atlantic basin. However, these specific backbarrier environments are scarce in the South Pacific, with cyclone records limited primarily to the period of modern observation. This instrumental record suggests a correlation with the El Niño-Southern Oscillation (ENSO), but longer records are necessary to test this relationship over geologic timescales and explore other potential climate drivers of tropical cyclone variability. Deep lagoons behind coral reefs are widespread in the Pacific and provide an alternative setting for developing long-term sedimentary reconstructions of tropical cyclone occurrence. Coarse-grained event deposits within the sediments of a back-reef lagoon surrounding Tahaa reveal a 5000year record of cyclone occurrences. Timing of recent high-energy deposits matches well with observed tropical cyclone strikes and indicates coarse deposits are storm derived. Longer records show tropical cyclone activity was higher from 5000 to 3800 and 2900 to 500 yrs BP. Comparison to records from the North Pacific (out-of-phase) and North Atlantic (in phase) suggests a coordinated pattern of storm activity across tropical cyclone basins over the mid-late Holocene. The changes in tropical cyclone activity we observe in the South Pacific and across other basins may be related to ENSO as well as precession driven changes in ocean-atmosphere thermal gradients.

*Published as: Toomey, M., J.P. Donnelly and J.D. Woodruff (2013). Reconstructing mid-late Holocene cyclone variability in the Central Pacific using sedimentary records from Tahaa, French Polynesia, QSR, 77, 181-189, doi: 10.1016/j.quascirev.2013.07.019 Reproduced with permission from Elsevier. 


\title{
Reconstructing mid-late Holocene cyclone variability in the Central Pacific using sedimentary records from Tahaa, French Polynesia
}

\author{
Michael R. Toomey ${ }^{\mathrm{a}, \mathrm{b}, *}$, Jeffrey P. Donnelly ${ }^{\mathrm{a}}$, Jonathan D. Woodruff ${ }^{\mathrm{c}}$ \\ a Department of Geology \& Geophysics, Woods Hole Oceanographic Institution, MS \#22, 360 Woods Hole Rd., Woods Hole, MA 02543, USA \\ ${ }^{\mathrm{b}}$ Department of Earth, Atmospheric, and Planetary Sciences, Massachusetts Institute of Technology, Cambridge, MA 02139, USA \\ ${ }^{\mathrm{c}}$ Department of Geosciences, University of Massachusetts, Amherst, MA 01003, USA
}

\section{A R T I C L E I N F O}

\section{Article history:}

Received 7 March 2013

Received in revised form

13 July 2013

Accepted 15 July 2013

Available online

\section{Keywords:}

Tropical cyclones

South Pacific

ENSO

Precession

\begin{abstract}
A B S T R A C T
We lack an understanding of the geographic and temporal controls on South Pacific cyclone activity. Overwash records from backbarrier salt marshes and coastal ponds have been used to reconstruct tropical cyclone strikes in the North Atlantic basin. However, these specific backbarrier environments are scarce in the South Pacific, with cyclone records limited primarily to the period of modern observation. This instrumental record suggests a correlation with the El Niño-Southern Oscillation (ENSO), but longer records are necessary to test this relationship over geologic timescales and explore other potential climate drivers of tropical cyclone variability. Deep lagoons behind coral reefs are widespread in the Pacific and provide an alternative setting for developing long-term sedimentary reconstructions of tropical cyclone occurrence. Coarse-grained event deposits within the sediments of a back-reef lagoon surrounding Tahaa reveal a 5000-year record of cyclone occurrences. Timing of recent high-energy deposits matches well with observed tropical cyclone strikes and indicates coarse deposits are storm derived. Longer records show tropical cyclone activity was higher from 5000 to 3800 and 2900 to $500 \mathrm{yrs}$ BP. Comparison to records from the North Pacific (out-of-phase) and North Atlantic (in phase) suggests a coordinated pattern of storm activity across tropical cyclone basins over the mid-late Holocene. The changes in tropical cyclone activity we observe in the South Pacific and across other basins may be related to ENSO as well as precession driven changes in ocean-atmosphere thermal gradients.
\end{abstract}

(c) 2013 Elsevier Ltd. All rights reserved.

\section{Introduction}

Historical cyclone records are scarce for French Polynesia, owing to the poor spatial coverage of populated islands and low ship traffic in the central South Pacific. Satellite monitoring since 1970 $\mathrm{AD}$ has greatly improved storm detection, yet the shortage of observations prior to this instrumental era limits our understanding of the environmental forcings driving long-term patterns in tropical cyclone activity within the basin.

On seasonal to annual time-scales, instrumental observations show that the El Niño-Southern Oscillation (ENSO) exerts significant control over tropical cyclone activity in the South Pacific (Revell and Goulter, 1986; Hastings, 1990; Basher and Zheng, 1995). Analysis of tropical cyclone genesis locations between 1939 and 1979 AD by Revell and Goulter (1986) revealed a northeastern

\footnotetext{
* Corresponding author. Department of Geology \& Geophysics, Woods Hole Oceanographic Institution, MS \#22, 360 Woods Hole Rd., Woods Hole, MA 02543, USA. Tel.: +1978 5053054 .

E-mail address: mrt02008@mit.edu (M.R. Toomey).

(southwestern) displacement during El Niño (La Niña). The eastward shift in cyclone origin locations during El Niños follows the migration of South Pacific Convergence Zone (SPCZ) and the establishment of favorable atmospheric conditions over French Polynesia (Revell and Goulter, 1986). These conditions do not significantly change the overall frequency of storms in the western/ central South Pacific (Hastings, 1990).

On longer-timescales, changes in insolation may also be influencing tropical cyclone frequency in the South Pacific. Modeling efforts by Korty et al. (2012) suggest that decreased storm season insolation during the mid-Holocene due to precession may have led to a steeper atmospheric thermal gradient and increased potential intensity in the South Pacific. However, precession driven changes in insolation are also thought to have limited El Niño-like variability during the mid-Holocene (Clement et al., 2000), possibly restraining tropical cyclone activity in the Central Pacific. Longer records are needed to resolve the relative influence of these competing factors on tropical cyclone variability.

Backbarrier beach overwash records have been successfully used to extend records of tropical cyclone landfalls in the North 
Atlantic (Liu and Fearn, 1993; Donnelly et al., 2001; Donnelly and Woodruff, 2007; Scileppi and Donnelly, 2007; Lane et al., 2011; Toomey et al., 2013) and in the North Pacific (Woodruff et al., 2009). Overwash deposits are formed when storm waves and surge over-top the barrier beach, moving sediment into the backbarrier setting. Deposition of coarser barrier beach derived material in the otherwise low-energy back-barrier environments provides a diagnostic signal. Likewise, deposition of coarse reef material in back-reef lagoons may serve as a similar proxy for tropical cyclone strikes and represent an unexplored archive of long-term storm activity. Under fair-weather conditions, wave energy typically dissipates within $100-500 \mathrm{~m}$ of the reef crest (Kench and Brander, 2006), limiting transport of coarse reef sediment (halimeda and coral) into the lagoon. However, large waves and storm surge during cyclone strikes may provide a key pathway for deposition of coarse layers in otherwise mud-rich deep lagoons.

Mobilization of barrier reef material, lagoon-ward transport and deposition in the back-barrier has been widely documented (summarized by Harmelin-Vivien (1994)) during modern tropical cyclones. In particular, Harmelin-Vivien and Laboute (1986) noted development of boulder ramparts on at Moorea and Tikehau Atoll, during the 1982/1983 cyclone season during which six storms threatened French Polynesia. A survey of Jaluit Atoll (Marshall Islands) following typhoon Ophelia (1958 AD) revealed large-scale erosion of reef material and deposition of rubble ridges on the reef flat (Blumenstock, 1958; Blumenstock et al., 1961) and coarsegrained sediment in the lagoon (McKee, 1959). Excavation of this deposit (Curray et al., 1970) revealed three earlier conglomerates dating to the late Holocene.

Geomorphic evidence of mid-late Holocene tropical cyclone activity in the Pacific, including coral conglomerates, is well documented in the literature (Table 1). Beach ridge formation in Northeastern Australia has also been attributed to large storms over the past several thousand years (Forsyth et al., 2010, 2012; Nott and Forsyth, 2012).

Here we provide a description of sediments collected from a back-barrier reef lagoon on Tahaa, French Polynesia. Preserved coarse-grained deposits are found to be a viable proxy of cyclone occurrence and provide one of the first reconstructions of tropical cyclone activity for the central South Pacific. The reconstruction is employed to address the following key questions: (1) How has tropical cyclone activity around French Polynesia changed over the mid-late Holocene, (2) is there a clear relationship between ENSO and cyclone frequency in the central South Pacific prior to the instrumental era and (3) what are the effects of different climatic regimes (e.g. ENSO, Precession) on central South Pacific cyclone activity?

\section{Study site}

Tahaa $\left(16^{\circ} \mathrm{S} 151^{\circ} \mathrm{W}\right)$ is located $225 \mathrm{~km}$ northwest of Tahiti and is the smaller remnant of a double-coned volcanic shield formed 2$3 \mathrm{Ma}$ (Guillou et al., 2005). Tahaa is closely neighbored by the island of Raiatea, $6 \mathrm{~km}$ to the south (Fig. 1). The barrier-reef system surrounding Tahaa follows a characteristic sequence of environs and depositional settings. In general, a $30-40 \mathrm{~m}$ deep lagoon is protected by a broad $1-2 \mathrm{~km}$ wide reef flat and narrow $50-100 \mathrm{~m}$ wide barrier reef. Our study site is located on the western side of the lagoon separating Tahaa and Raiatea (Fig. 1).

Reliable instrumental data for the central South Pacific begins in 1961 AD (International Best Track Archive for Climate Stewardship-IBTrACS) (Knapp et al., 2010). Since the onset of this record eight tropical storms (Australian Scale) have passed within $110 \mathrm{~km}$ (approximately the scale of tropical cyclone strength winds and defined TC 'strike') of Tahaa (Fig. 1), with these modern events providing a means for calibrating a cyclone proxy from Tahaa sediments. Of the eight tropical storms impacting the site since $1961 \mathrm{AD}$, only three had winds speeds in excess of 34 knots (10-min sustained winds). These include Cyclone Lisa in $1983 \mathrm{AD}$ as a category 1 storm, and Cyclone Rewa in $1983 \mathrm{AD}$ and Cyclone Osea in 1997 AD, both category 3 storms.

Prior to the best-track data set, historic archives document 14 tropical cyclones affected the Society Islands between 1825 and 1966 AD (Teissier, 1982). Of these, detailed accounts of only the 1878, 1903, 1905 and 1906 AD storms exist and given the lack of direct meteorological observations, the intensity, path and overall impact of historic events at our site remain unclear. Efforts to extend or improve these records using geologic proxies have so far been limited.

Geologic reconstructions of overwash occurrences for French Polynesia are restricted to dated reef blocks and coral conglomerate deposits along reef flats. Thirteen reef blocks or conglomerate deposits thrust onto the reef flat during past storm events have been identified on Tahaa and nearby islands (within $110 \mathrm{~km}$ of Tahaa: Raiatea, Bora Bora $(\sim 30 \mathrm{~km} \mathrm{NW})$, Tupai $(\sim 60 \mathrm{~km} \mathrm{NW})$, Maupiti $(\sim 85 \mathrm{~km} \mathrm{NW})$, Table 1). Radiocarbon dating of this over-washed material revealed calibrated ages between 920 and 4405 yrs BP, with reef conglomerate deposits on Tahaa and Raiatea dating to 2715 and 4405 yrs BP. The small number of events within these records limits characterization of higher frequency patterns, however, they provide a valuable data set for cross calibration of higher resolution, continuous reconstructions from the lagoonal sediments of Tahaa.

\section{Methods}

To reconstruct the overwash history preserved in the lagoonal sediments of Tahaa we acquired high-resolution seismic profiles and 26 vibracores aboard the S.S.V. Robert C. Seamans between the 10th and 20th of January 2009. Sub-bottom stratigraphy was mapped using a Benthos CHIRP-II, sweeping a bandwidth range of $2-7 \mathrm{kHz}$. Low signal attenuation in the lagoon sediments allowed for penetration of over $30 \mathrm{~m}$. Post-processing of seismic data in Kingdom Suite 8.4 (Seismic Microtechnology INC) allowed for identification of core sites with thick depositional sequences close to the barrier where susceptibly to overwash is the greatest.

Coring was carried out using a Rossfelder P-3 underwater vibracore. Following recovery, cores were sectioned and shipped to the Woods Hole Oceanographic Institution for further processing. There, each core was split and refrigerated in order to prevent drying prior to analysis. Major transitions in color, grain size and organic content were identified and used to select TAH VC3 and TAH VC4 for more detailed analyzes of storm overwash. Overwash events in TAH VC3 and TAH VC4 were identified by increases in particle size. Each core was contiguously sampled at $1 \mathrm{~cm}$ resolution. For an improved modern calibration the top $25 \mathrm{~cm}$ of TAH VC3 was sampled at a higher resolution of $1 / 2 \mathrm{~cm}$. Following subsampling, sediments were heated at $100{ }^{\circ} \mathrm{C}$ for $5 \mathrm{~h}$ and weighed to obtain their dry mass. Coarse material was then separated using standard $63 \mu \mathrm{m}, 250 \mu \mathrm{m}$ and $2 \mathrm{~mm}$ sieves.

Age constraints in the cores were obtained using both ${ }^{210} \mathrm{~Pb}$ and radiocarbon dating (Figs. 2 and 3). Standard ${ }^{210} \mathrm{~Pb}$ methods were used to establish chronology: (1) bulk subsamples were dried and homogenized before counting on a Canberra germanium well detector, with ${ }^{210} \mathrm{~Pb}$ activity computed using gamma spectroscopy of the $46.54 \mathrm{keV}$ photopeak and $(2)^{210} \mathrm{~Pb}$ chronology was determined assuming a constant initial concentration model (CIC) with supported ${ }^{210} \mathrm{~Pb}$ defined by activities at depth (Appleby and Oldfield, 1978,1983 ). Radiocarbon dating was used to determine a chronology in each core below the detection limit of excess ${ }^{210} \mathrm{~Pb}$, with 
Table 1

Compilation of central South Pacific coral conglomerate and reef block deposits from the literature. Dates highlighted in gray were corrected for ${ }^{13} \mathrm{C}$ fractionation based on dating/correction information available for each entry or correspondence with authors. Direction arrow, indicates the orientation of the island where the deposit was found. Age reported is the date given in the literature. The maximum probability peak age takes into account reservoir effect ( 400 yrs), fractionation and the Marine09 calibration curve. More information on many of these samples is summarized in Pirazzoli and Montaggioni, 1988. Note: Gif_6561 was found stratagraphically out of order.

\begin{tabular}{|c|c|c|c|c|c|c|c|c|}
\hline Group & Island & $\pi$ & Lab code & $\begin{array}{l}\text { Age reported } \\
\text { (yrs BP) }\end{array}$ & $\begin{array}{l}\text { Age error } \\
\text { (yrs BP) }\end{array}$ & $\begin{array}{l}\text { Max prob } \\
\text { peak (yrs BP) }\end{array}$ & Dated material & Ref \\
\hline \multirow[t]{24}{*}{ Society } & Manuae & $\mathrm{NE}$ & Gif_6414 & 2640 & 60 & 2790 & Conglomerate (Calcirudite) & Pirazzoli, 1985b \\
\hline & Maupiti & $\mathrm{NE}$ & Gif_6087 & 2700 & 80 & 2860 & Reef Block (Porites Lobata) & Pirazzoli, 1985b \\
\hline & Maupiti & NW & Gif_6563 & 2200 & 60 & 2300 & Conglomerate (Calcarenite) & Pirazzoli, 1985b \\
\hline & Tupai & NW & Gif_6411 & 1950 & 60 & 1970 & Reef Block & Pirazzoli, 1985b \\
\hline & Tupai & NW & Gif_6409 & 1740 & 60 & 1720 & Reef Block & Pirazzoli, 1985b \\
\hline & Tupai & $\mathrm{E}$ & Gif_6505 & 2910 & 60 & 3165 & Conglomerate & Pirazzoli, 1985b \\
\hline & Tupai & E & Gif_6506 & 2780 & 60 & 2965 & Conglomerate & Pirazzoli, 1985b \\
\hline & Bora Bora & $\mathrm{N}$ & Gif_6562 & 2500 & 60 & 2700 & Conglomerate & Pirazzoli, 1985b \\
\hline & Bora Bora & $\mathrm{N}$ & Gif_893 & 2250 & 130 & 2330 & Reef Block & Guilcher, 1969; Pirazzoli, 1985b \\
\hline & Bora Bora & $\mathrm{N}$ & Gif_6916 & 1650 & 50 & 1610 & Conglomerate & Pirazzoli and Montaggioni, 1988 \\
\hline & Bora Bora & $\mathrm{N}$ & Gif_6915 & 1950 & 50 & 1970 & Conglomerate & Pirazzoli and Montaggioni, 1988 \\
\hline & Bora Bora & $\mathrm{N}$ & Gif_6561 & 980 & 50 & 920 & Conglomerate & Pirazzoli, 1985b \\
\hline & Raiatea & $\mathrm{E}$ & Gif_6097 & 3880 & 80 & 4405 & Conglomerate (Porites) & Pirazzoli, $1985 \mathrm{~b}$ \\
\hline & Tahaa & $\mathrm{N}$ & Gif_6917 & 2530 & 60 & 2715 & Conglomerate & Pirazzoli and Montaggioni, 1988 \\
\hline & Moorea & $\mathrm{E}$ & Gif_6100 & 2670 & 60 & 2835 & $\begin{array}{l}\text { Conglomerate } \\
\text { (Calcirudite) }\end{array}$ & $\begin{array}{l}\text { Montaggioni and Pirazzoli, 1984; } \\
\text { Pirazzoli, 1985b }\end{array}$ \\
\hline & Moorea & E & Gif_6099 & 2320 & 60 & 2395 & Conglomerate (Calcirudite) & $\begin{array}{l}\text { Montaggioni and Pirazzoli, 1984; } \\
\text { Pirazzoli, 1985b }\end{array}$ \\
\hline & Moorea & E & Gif_6098 & 2690 & 70 & 2850 & Conglomerate (Calcarenite) & $\begin{array}{l}\text { Montaggioni and Pirazzoli, 1984; } \\
\text { Pirazzoli, 1985b }\end{array}$ \\
\hline & Moorea & $\mathrm{NE}$ & Gak_9974 & 6070 & 130 & 6725 & Conglomerate (Acropora) & Montaggioni and Pirazzoli, 1984 \\
\hline & Moorea & NW & Gif_3880 & 2280 & 100 & 2340 & Conglomerate & $\begin{array}{l}\text { Chevalier and Salvat, 1976; } \\
\text { Pirazzoli, 1985b }\end{array}$ \\
\hline & Moorea & E & Gak_9975 & 3340 & 120 & 3430 & Conglomerate (Calcirudite) & Montaggioni and Pirazzoli, 1984 \\
\hline & Tahiti & NW & Gif_6101 & 2610 & 60 & 2760 & Coglomerate & Pirazzoli, 1985b \\
\hline & Tahiti & $\mathrm{NE}$ & Gif_6103 & 110 & 60 & 130 & Conglomerate (Framework) & Pirazzoli, 1985b \\
\hline & Tahiti & $\mathrm{N}$ & Gif_6102 & 3660 & 60 & 4085 & Conglomerate (Framework) & Pirazzoli, 1985b \\
\hline & Tahiti Iti & $\mathrm{N}$ & Gif_6104 & 2850 & 60 & 3070 & Conglomerate (Calcirudite) & Pirazzoli, 1985b \\
\hline \multirow[t]{22}{*}{ Tuamotu } & Mataiva & S & Gak_9970 & 5420 & 110 & 5990 & Conglomerate (Porites) & $\begin{array}{l}\text { Montaggioni and Pirazzoli, 1984; } \\
\text { Pirazzoli and Montaggioni, } 1986\end{array}$ \\
\hline & Mataiva & SW & Gak_9971 & 5230 & 140 & 5840 & Conglomerate & $\begin{array}{l}\text { Montaggioni and Pirazzoli, 1984; } \\
\text { Pirazzoli and Montaggioni, } 1986\end{array}$ \\
\hline & Mataiva & SW & Gak_9972 & 3470 & 120 & 3580 & Conglomerate & $\begin{array}{l}\text { Montaggioni and Pirazzoli, 1984; } \\
\text { Pirazzoli and Montaggioni, } 1986\end{array}$ \\
\hline & Rangiroa & $\mathrm{NE}$ & HV_12282 & 705 & 65 & 660 & Conglomerate & $\begin{array}{l}\text { Pirazzoli, 1985a; Pirazzoli and } \\
\text { Montaggioni, } 1986\end{array}$ \\
\hline & Rangiroa & Lagoon & HV_12283 & 2775 & 60 & 2960 & Conglomerate & $\begin{array}{l}\text { Pirazzoli, 1985a; Pirazzoli and } \\
\text { Montaggioni, } 1986\end{array}$ \\
\hline & Rangiroa & $\mathrm{NE}$ & LJ_1372 & 4900 & 300 & 5465 & Conglomerate & Hubbs and Bien, 2006 \\
\hline & Arutua & SE & HV_12280 & 1380 & 70 & 1310 & Conglomerate & Pirazzoli and Montaggioni, 1986 \\
\hline & Arutua & SE & HV_12281 & 1565 & 65 & 1520 & Conglomerate & Pirazzoli and Montaggioni, 1986 \\
\hline & Apataki & sW & HV_12278 & 3135 & 65 & 3415 & Conglomerate & Pirazzoli and Montaggioni, 1986 \\
\hline & Apataki & sW & HV_12279 & 2990 & 130 & 3265 & Conglomerate & Pirazzoli and Montaggioni, 1986 \\
\hline & Apataki & sW & HV_12277 & 1580 & 70 & 1530 & Conglomerate & Pirazzoli and Montaggioni, 1986 \\
\hline & Takapoto & $\mathrm{E}$ & Gak_9976 & 5020 & 140 & 5580 & Conglomerate & $\begin{array}{l}\text { Montaggioni and Pirazzoli, 1984; } \\
\text { Pirazzoli and Montaggioni, } 1986\end{array}$ \\
\hline & Takapoto & SW & HV_12276 & 1320 & 80 & 1275 & Conglomerate & $\begin{array}{l}\text { Montaggioni and Pirazzoli, 1984; } \\
\text { Pirazzoli and Montaggioni, } 1986\end{array}$ \\
\hline & Takapoto & SW & HV_12275 & 1580 & 70 & 1530 & Conglomerate & $\begin{array}{l}\text { Montaggioni and Pirazzoli, 1984; } \\
\text { Pirazzoli and Montaggioni, } 1986\end{array}$ \\
\hline & Hikueru & NW & HV_13015 & 1470 & 60 & 1400 & Reef Block & Pirazzoli et al., 1988 \\
\hline & Pukarua & NW & HV_13021 & 3875 & 70 & 4400 & Conglomerate & Pirazzoli et al., 1988 \\
\hline & Vahitahi & W & Pa_162 & 3960 & 110 & 4500 & Conglomerate & Pirazzoli et al., 1987 \\
\hline & Mururoa & E & Gig_631 & 5550 & 300 & 6180 & Conglomerate & Delibrias et al., 1969 \\
\hline & Haо & $\mathrm{NE}$ & Gif_1667 & 3300 & 100 & 3615 & Conglomerate & Pirazzoli et al., 1988 \\
\hline & Nukutavake & NW & HV_13010 & 1925 & 50 & 1935 & Reef Block & Pirazzoli et al., 1988 \\
\hline & Vairaatea & NW & HV_13014 & 3995 & 65 & 4525 & Reef Block & Pirazzoli et al., 1988 \\
\hline & Tureia & $\mathrm{N}$ & HV_13001 & 1220 & 65 & 1180 & Reef Block & Pirazzoli et al., 1988 \\
\hline \multirow[t]{7}{*}{ Gambier } & Mangareva & $\mathrm{N}$ & HV_12264 & 3035 & 95 & 3325 & Conglomerate & Pirazzoli and Montaggioni, 1987 \\
\hline & Mangareva & $\mathrm{N}$ & HV_12263 & 2815 & 100 & 3025 & Conglomerate & Pirazzoli and Montaggioni, 1987 \\
\hline & Mangareva & NW & HV_12262 & 1260 & 65 & 1235 & Conglomerate & Pirazzoli and Montaggioni, 1987 \\
\hline & Temoe & NE & HV_12266 & 3170 & 60 & 3450 & Conglomerate (Pebble) & $\begin{array}{l}\text { Pirazzoli, 1987; Pirazzoli and } \\
\text { Montaggioni, } 1987\end{array}$ \\
\hline & Temoe & $\mathrm{N}$ & HV_12267 & 3405 & 85 & 3755 & Conglomerate (Pebble) & Pirazzoli, 1987 \\
\hline & Temoe & $\mathrm{N}$ & HV_12268 & 2875 & 75 & 3125 & Conglomerate (Pebble) & Pirazzoli, 1987 \\
\hline & Temoe & w & HV_12269 & 3145 & 95 & 3430 & Conglomerate (Shell) & Pirazzoli, 1987 \\
\hline Austral & Tubuai & NE & HV_13005 & 1400 & 55 & 1330 & Conglomerate & Pirazzoli and Montaggioni, 1988 \\
\hline
\end{tabular}


Table 1 (continued)

\begin{tabular}{lllllllll}
\hline Group & Island & $\boldsymbol{\lambda}$ & Lab code & $\begin{array}{l}\text { Age reported } \\
\text { (yrs BP) }\end{array}$ & $\begin{array}{l}\text { Age error } \\
\text { (yrs BP) }\end{array}$ & $\begin{array}{l}\text { Max prob } \\
\text { peak (yrs BP) }\end{array}$ & Dated material & Ref \\
\hline Cook & Suwarrow & NW & NZ_6102 & 2000 & 60 & 2045 & Conglomerate (Porites) & Woodroffe et al., 1990 \\
& Suwarrow & NW & NZ_6104 & 4460 & 50 & 5235 & Conglomerate (Porites) & Woodroffe et al., 1990 \\
& Suwarrow & NE & NZ_6100 & 3560 & 50 & 3965 & Conglomerate (Porites) & Woodroffe et al., 1990 \\
& Suwarrow & NE & NZ_6109 & 2620 & 50 & 2770 & Conglomerate (Porites) & Woodroffe et al., 1990 \\
& Suwarrow & NE & NZ_6111 & 3630 & 50 & 4070 & Conglomerate & Woodroffe et al., 1990 \\
\hline
\end{tabular}

samples analyzed at the National Ocean Science Accelerator Mass Spectrometry Facility (NOSAMS) in Woods Hole, Massachusetts. Standard methods were used for dating bulk organic carbon, while continuous flow gas bench methods (von Reden et al., 2012) were employed to date bulk carbonate material (Table 2). Radiocarbon ages were calibrated in Matlab using procedures outlined for CALIB 6.0 (Reimer et al., 2009), with a standard marine correction applied to the bulk carbonate samples. Best-fit linear sedimentation rates were used to set the age model for each core (below $210 \mathrm{~Pb}$ chronology).

Coral conglomerate and reef block ${ }^{14} \mathrm{C}$ ages from the literature (Table 1) were reported in an effort to provide an independent test of storm activity across the entire cyclone basin. Observations were first compiled and then standardized using Marine09 (Reimer et al., 2009) and a $400 \mathrm{yr}$ marine reservoir. Older dates were also corrected for ${ }^{13} \mathrm{C}$ fractionation (highlighted in gray). The resulting probability distributions and age uncertainties for each event were then used to determine the likely number of events in $250 \mathrm{yr}$ windows. A similar exercise was carried out for the beach ridge deposits (Optically simulated luminescence (OSL) dated) reported for Northeastern Australia (Forsyth et al., 2010, 2012; Nott and Forsyth, 2012) but in this case age errors were assumed to be normally distribution.

In addition to the study's sedimentary reconstructions, the potential correlation between ENSO and storminess in the Society Islands during the satellite era (1970-2009 AD) was also tested for its statistical significance using methods similar to those of Revell and Goulter (1986). The genesis locations of storms in the central South Pacific in the Best Track Archive for Climate Stewardship extends as far back as 1907 AD (IBTrACS (Knapp et al., 2010)). However, statistical analyses are restricted to more accurate data from the satellite era ( $>1970$ AD), with the Pearson's product-
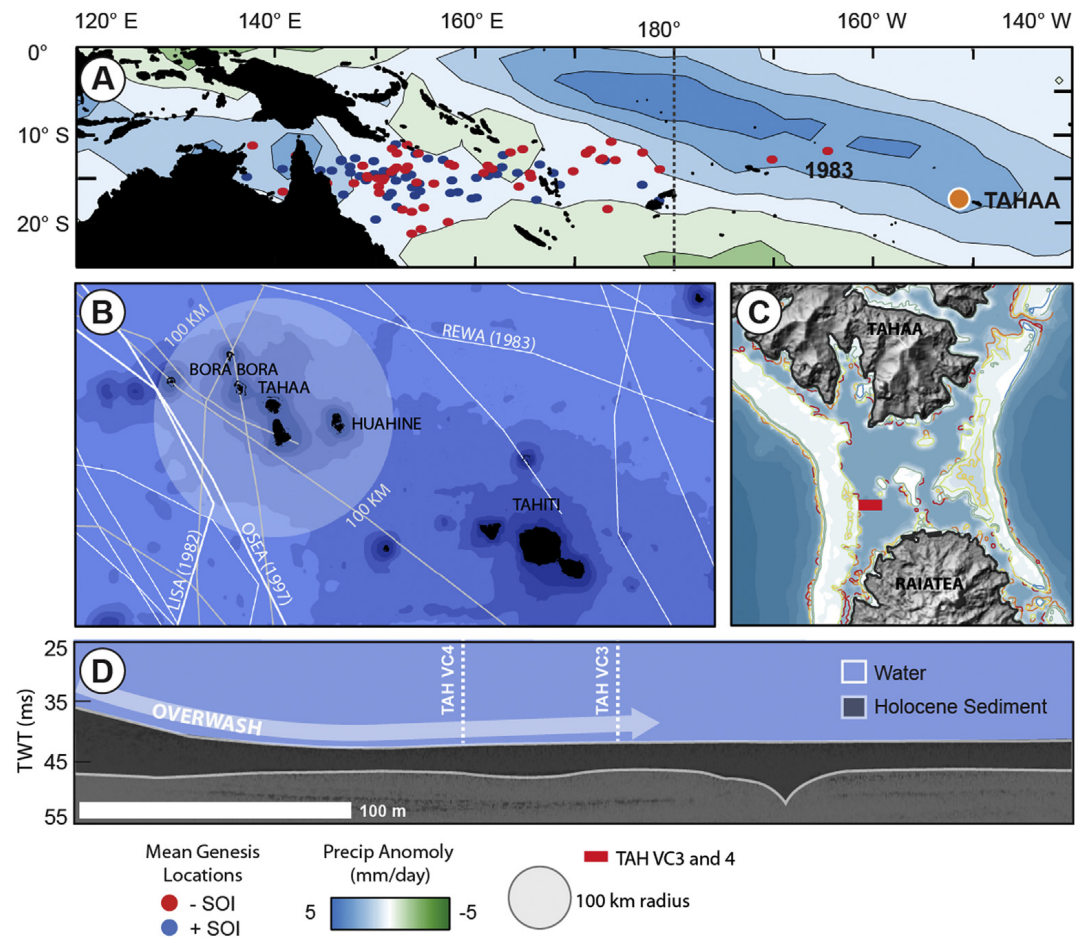

Fig. 1. Site location, geomorphology and local bathymetry. (A) Map showing annual mean genesis locations in the South Pacific relative to modes of SOI: positive (blue circle) and negative (red circle). Location of Tahaa is shown by orange dot. Background colors indicate storm season (NDJF) precipitation anomalies for periods of negative SOI (CPC Merged Analysis of Precipitation). (B) Cyclone tracks from the IBTrACs data set. Storms passing within $100 \mathrm{~km}$ at $\geq$ CAT 1 strength ( $>34$ knots 10-min maximum sustained wind; Lisa (1982); Osea (1997)) are given by thick white line. Less intense storms passing within $100 \mathrm{~km}$ are shown by gray lines. Tracks of all other storms are drawn in thin white lines. Rewa (CAT 3 ) passed within approximately $105 \mathrm{~km}$ of our site. (C) Bathymetric and shaded relief map of Tahaa and Raiatea. Location of core sites for tropical cyclone (TAH VC3 and TAH4) reconstructions are given by the red line. White and light blue areas show barrier reef and reef flat areas. (D) Seismic profile across coring site. White dashed lines indicate the location of TAH VC4 and TAH VC3. Holocene sediments are highlighted in dark gray while material interpreted as older Pleistocene sediments are shown in light gray. (For interpretation of the references to color in this figure legend, the reader is referred to the web version of this article.) 

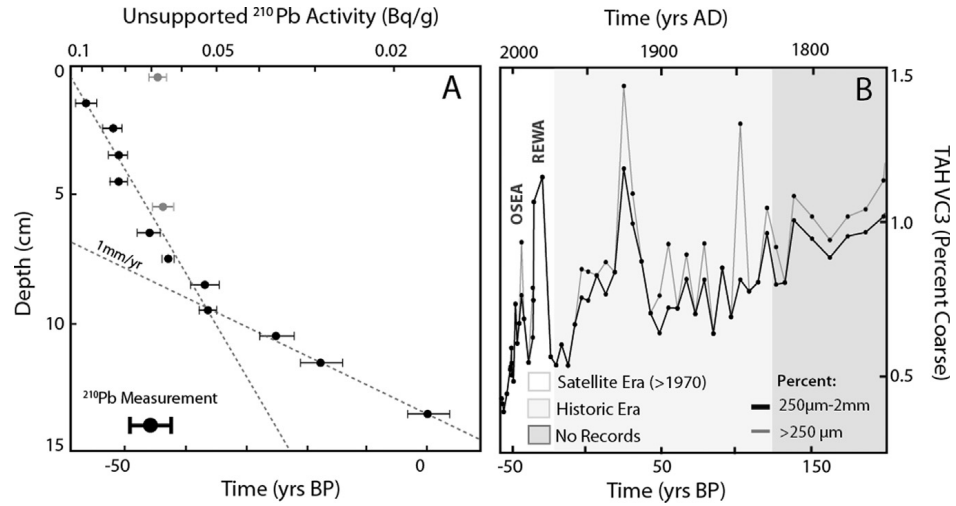

Fig. 2. Chronology and grain-size from TAH VC3 core-top. (A) Unsupported ${ }^{210} \mathrm{~Pb}$ chronology. Chronology was interpolated using an initial concentration model and the black data points showing the unsupported ${ }^{210} \mathrm{~Pb}$ (no reversals). Note activity increases from right to left in plot. Supported ${ }^{210} \mathrm{~Pb}$ was approximately 0.065 (Bq/g). (B) Comparison of historic storm events to coarse grained deposition in TAH VC3. White area highlights satellite era (present-1970 AD). Light gray shows the historic interval (1970-1831 AD). No cyclone record exists prior to $1831 \mathrm{AD}$ (dark gray)

moment correlation test used to quantitatively evaluate the connection between mean genesis location of a storm season and the year's corresponding Southern Oscillation Index value (SOI, Climate and Global Dynamics Division, National Center for Atmospheric Research (NCAR)).

\section{Results}

4.1. Statistical analyses of modern storms

Fig. 1A presents the annual mean genesis locations in the South Pacific relative to modes of SOI with the Pearson's product-moment

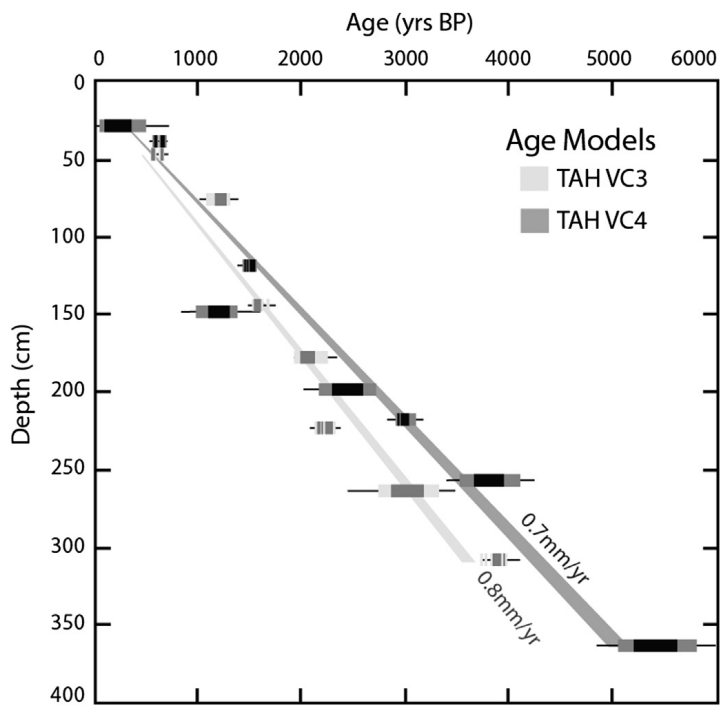

Fig. 3. Radiocarbon chronologies for TAH VC3 (light gray) and TAH VC4 (dark gray). Each bar represents an individual radiocarbon date. Darker inner bars show $1 \sigma$ ranges. $2 \sigma$ ranges are given by lighter shaded bars. Black line shows range of ages generated iteratively (1000 times) resampling the probability distribution for each date. Shade area (TAH VC3: light gray; TAH VC4: dark gray) shows one standard deviation window (based on resampling procedure) around mean sedimentation rate. test revealing a statistically significant correlation. During periods when SOI was negative storms formed further North $(r=-0.5$; $p<0.001)$ and East $(r=-0.5 ; p=0.001)$ likely driven by migrations of the South Pacific Convergence Zone (SPCZ) (Revell and Goulter, 1986). This analysis is therefore consistent with SOI driving changes in the location of storm formation, although the number of storms in a given cyclone season was not as strongly related to SOI $(r=-0.3216 ; p<0.05)$.

\subsection{Chronology}

Measured ${ }^{210} \mathrm{~Pb}$ activity indicates supported levels of $0.065(\mathrm{~Bq} /$ g). Unsupported ${ }^{210} \mathrm{~Pb}$ activity is indistinguishable from this background below $14 \mathrm{~cm}$. Above this, our ${ }^{210} \mathrm{~Pb}$ profile indicates accumulation rates increased substantially between 1970 and 1990 AD (Fig. 2A). A similar pattern of ${ }^{210} \mathrm{~Pb}$ activity was observed on Tahiti and related to increased anthropogenic disturbance (Harris et al., 2001). Additionally, bleaching events in recent years have caused widespread damage to reefs in the Society Islands (Gleason, 1993) as well as around the Pacific (Glynn, 1984) and may have led to increased degradation of the reef and sediment supply to the lagoon. Prior to $1970 \mathrm{AD},{ }^{210} \mathrm{~Pb}$ suggest an accumulation rate of approximately $1 \mathrm{~mm} / \mathrm{yr}$, consistent with long-term sedimentation

Table 2

List of radiocarbon dates and ages. Bulk organic samples were dated using conventional AMS methods (highlighted in gray). Bulk carbonate material was dated using continuous flow, gas bench methods.

\begin{tabular}{llcrl}
\hline Core & Depth $(\mathrm{cm})$ & ${ }^{14} \mathrm{C}$ age & Error & Material \\
\hline TAH VC3 & $47-48$ & 655 & 25 & Bulk organic \\
TAH VC3 & $77-78$ & 1659 & 54 & Bulk $\mathrm{CaCO}_{3}$ \\
TAH VC3 & $146-147$ & 1680 & 25 & Bulk organic \\
TAH VC3 & $180-181$ & 2434 & 51 & Bulk $\mathrm{CaCO}_{3}$ \\
TAH VC3 & $226-227$ & 2200 & 35 & Bulk organic \\
TAH VC3 & $266-267$ & 3208 & 125 & ${\text { Bulk } \mathrm{CaCO}_{3}}$ \\
TAH VC3 & $311-313$ & 3590 & 35 & Bulk organic \\
TAH VC4 & $29-30$ & 576 & 142 & Bulk $\mathrm{CaCO}_{3}$ \\
TAH VC4 & $39-40$ & 565 & 40 & Bulk organic \\
TAH VC4 & $119-120$ & 1560 & 25 & Bulk organic \\
TAH VC4 & $149-150$ & 1606 & 101 & Bulk $\mathrm{CaCO}_{3}$ \\
TAH VC4 & $199-200$ & 2675 & 102 & Bulk $\mathrm{CaCO}_{3}$ \\
TAH VC4 & $219-220$ & 2850 & 30 & Bulk organic \\
TAH VC4 & $259-260$ & 3828 & 109 & Bulk $\mathrm{CaCO}_{3}$ \\
TAH VC4 & $364-365$ & 5095 & 150 & Bulk $\mathrm{CaCO}_{3}$ \\
\hline
\end{tabular}


rates $(\mathrm{TAH} \mathrm{VC} 3=0.8 \mathrm{~mm} / \mathrm{yr}$, TAH VC4 $=0.7 \mathrm{~mm} / \mathrm{yr}$ ) based on radiocarbon results (Fig. 3) given the expected effect of compaction deeper in the sediment column. Seismic surveying indicates relatively uniform sediment thickness $(\sim 5 \mathrm{~m})$ and accumulation rates throughout the lagoon separating Tahaa and Raiatea. However, slightly higher lagoonal accumulation rates appear to occur proximal to the reef flat and in local depressions or channels (Fig. 1D).

\subsection{Sedimentology}

TAH VC3 and VC4 are composed of fine gray aragonite rich mud with only minor shifts in sediment color and composition. Observable organic deposition is limited to the uppermost section of each core, which show streaking of brown mud. Mollusk shells, polychaete tube fragments, coral clasts, foraminifera and other reef derived material make up the coarse fraction $(>63 \mu \mathrm{m})$, a finding consistent with observation elsewhere in the Leeward Society Islands (Gischler, 2011). Grain-size is very coarse (median grain size or $\mathrm{d} 50 \cong 500 \mu \mathrm{m}$ ) on the reef flat but decreases rapidly ( $\mathrm{d} 50 \cong 30$ $25 \mu \mathrm{m}$ ) moving landward in the lagoon (e.g. TAH VC4/VC3).

Comparison of recent coarse-grained deposition with modern cyclone events reveals a strong correspondence (Fig. 2B). The timing of two coarse fraction peaks from the top of TAH VC3 matches with the observed passage of tropical cyclones Rewa (1983, Category 3), Lisa (1983, Category 1) and Osea (1997, Category 3 ), the strongest events of the instrumental era for this site.

Sedimentary records from Tahaa (TAH VC3 and TAH VC4) also reveal substantial variability in grain size over the Holocene (Fig. 4), as well as different trends for percent coarse ( $>250 \mu \mathrm{m}$ and $250 \mu \mathrm{m}$ to $2 \mathrm{~mm}$ ) relative to the fraction of very fine to fine sand (i.e. 63$250 \mu \mathrm{m})$. Gradual trends dominate within the finer sand fraction (63-250 $\mu \mathrm{m}$, Fig. 4A) and are largely independent from the event stratigraphy derived from coarser material (i.e. $>250 \mu \mathrm{m}$ ). The percent of fine sand in TAH VC4 decreases rapidly from $>20$ percent at 5000 yrs BP to 10 percent by 3500 yrs BP before tapering to 7 percent at $2500 \mathrm{yrs} \mathrm{BP}$. The fine sand fraction then increases slightly from 1500 to 1000 yrs BP followed by a relatively stable percentage of just above 10 percent over the last 1000 yrs. In comparison, background fractions of percent coarse (as defined by the fraction $>250 \mu \mathrm{m}$ and $250 \mu \mathrm{m}$ to $2 \mathrm{~mm}$ ) remain relatively steady through time, with abrupt and isolated peaks becoming more dominate features within these time-series. Two prominent intervals of elevated peaks in percent coarse occur between 5000 and 3800 yrs BP, as well as from 2900 to 500 yrs BP (Fig. 4B,C). The largest peaks in percent coarse ( $250 \mu \mathrm{m}$ to $2 \mathrm{~mm}$ ) in TAH VC4 occur around 4200 , $2800,1900,1500$ and 500 yrs BP and are roughly concurrent, within error of the age model, with similar peaks in TAH VC3. A number of reef block and conglomerate deposits from the Leeward Islands (FP) also occur within a short interval ( $\pm 100 \mathrm{yrs})$ of prominent coarse peaks in our longer records (TAH VC3 and VC4, Fig. 4B,C). In particular, two such deposits, dated to $\sim 1900$ yrs BP, match well with the largest peaks. Emplacement of large coarse-grained layers is mostly absent in both records over the past 500 yrs and particularly during the period of modern observation. For instance, the peak associated with hurricane Rewa, the largest event during the satellite era ( $>1970 \mathrm{AD}$ ) is considerably smaller ( $\sim 1.5$ percent coarse) than many of the events ( $>5$ percent coarse) during previous active intervals. This indicates that the recent past may be inadequate in assessing possible future tropical cyclone risk in French Polynesia.

\subsection{Coral conglomerates, reef blocks and beach ridges}

A compilation of coral conglomerate and reef block dates reported in the literature (Table 1) suggests their formation has varied considerably over the past 5000 years. In the Society Islands

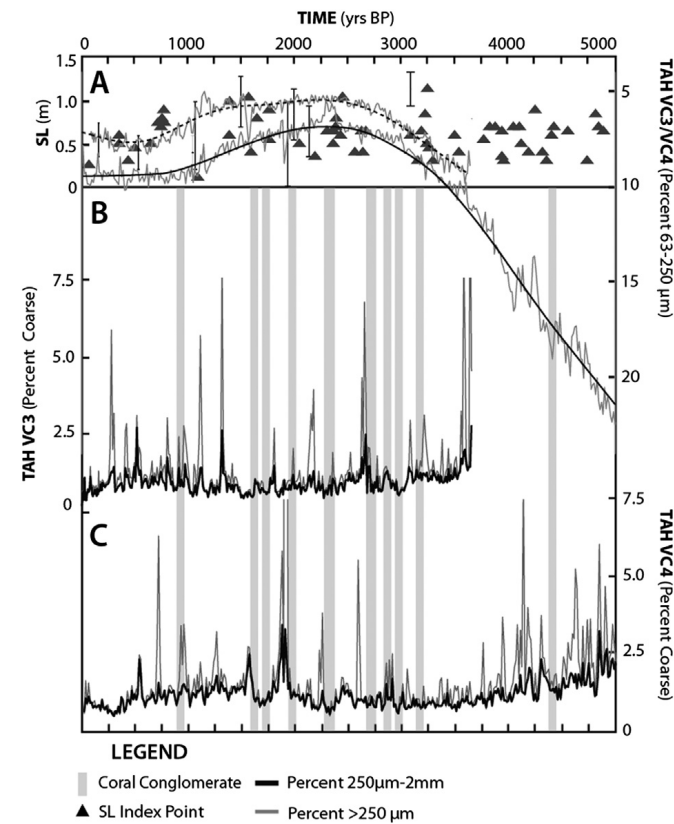

Fig. 4. Comparison of fine sand $(63-250 \mu \mathrm{m}$ ) and coarse grain influx ( $>250 \mu \mathrm{m}$ and $250 \mu \mathrm{m}$ to $2 \mathrm{~mm}$ fraction) with Holocene sea-level (SL) changes. (A) Fine sand fraction $(63-250 \mu \mathrm{m})$ for TAH VC3 (dashed) and TAH VC4 (solid). Note $y$-axis is reversed. Black triangles indicate paleo sea-level heights inferred from subaerial corals (Pirazzoli and Montaggioni, 1988) and re-calibrated using Marine09. Coral conglomerate and reef block deposits on Tahaa, Raiatea, Bora Bora, Tupai and Maupiti (Table 1) inferred here to be storm deive are highlighted by vertical bars for compaison to peeks in our to bestom do overwash records (below). (B) Coarse grained ( $>250 \mu \mathrm{m}$ : gray line and $250 \mu \mathrm{m}$ to
$2 \mathrm{~mm}$ fraction: black line) deposition in TAH VC3 and (C) TAH VC4.

(Fig. 5B, black line) a large increase in the number of deposits is observed between 3250 and 1500 yrs BP. A similar (3500-1000 yrs $\mathrm{BP})$ increase in event frequency is observed for the entire central South Pacific (Fig. 5B, black dashed line). The broader peak around 3000 yrs BP in this record (as compared to the Society Islands alone) mostly results from events in the Gambier Islands ( $1500 \mathrm{~km}$ SE Tahiti) around this time. In contrast, formation of beach ridges in Northeastern Australia (e.g. (Forsyth et al., 2010, 2012; Nott and Forsyth, 2012)) is highest from 4000 to 3000 yrs BP, 1500 to 1000 yrs BP and 750 yrs BP to present (gray line).

\section{Discussion}

Derived sedimentary archives demonstrate that deposition of high-energy layers in Tahaa is closely linked with observed tropical cyclone strikes and dated reef block and conglomerate deposits, and are therefore inferred to be storm-induced. Below we provide evidence against alternative mechanisms for changes in grain-size (sea level, tsunamis), and conclude that the two intervals ( 5000-3800 and $2900-500$ yrs BP) of increased coarse-grained deposition within the lagoon are likely related to higher tropical cyclone activity.

\subsection{Confounding effects}

Deposition of coarse sand ( $>250 \mu \mathrm{m})$ layers in TAH VC3 and VC4 appears to be relatively unaffected by mid-late Holocene sea level changes in the Pacific (Fig. 4). Identified transitions in coarse 


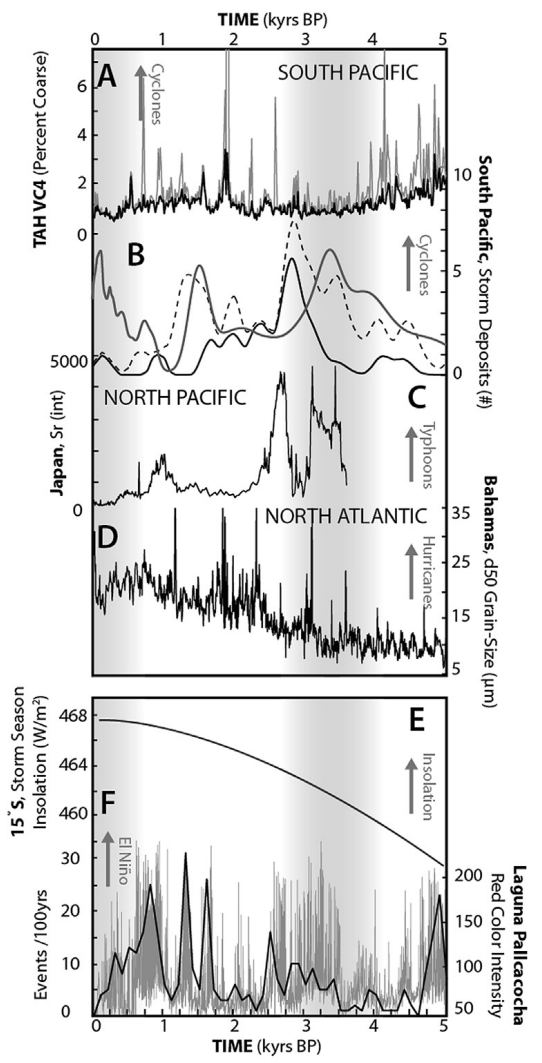

Fig. 5. Comparison of tropical cyclone records from Tahaa, the North Pacific and North Atlantic with records of hypothesized climate forcings. (Top) Tropical cyclone reconstructions from Tahaa (A) Percent $>250 \mu \mathrm{m}$ (gray) and $63-250 \mu \mathrm{m}$ (black) for TAH VC4 (B) Coral conglomerate and reef blocks (Table 1) from the Society Islands (black line) and the entire Central South Pacific (black dashed line). Record of tropical cyclone deposited beach ridges from Northeastern Australia (compiled in: (Nott and Forsyth, 2012)) - gray line (C) Japan (Woodruff et al., 2009), and (D) Bahamas. (E) Storm season (NDJF) incoming solar insolation at $15^{\circ} \mathrm{S}$ ((Huybers, 2012), and references therein). (F) Inferred changes in Holocene El Niño frequency based on red-color intensity in sediments from Laguna Pallcacocha, Ecuador (Moy et al., 2002).

material deposition at 5000, 3800, 2900 and 500 yrs BP do not coincide closely with the established $5000-1250$ yrs BP age range of the mid-Holocene highstand in French Polynesia ((Grossman et al., 1998) and refs therein). Given the relatively small magnitude $(\sim 1-2 \mathrm{~m})$ of sea-level rise over this interval relative to the scale of waves $(8-10 \mathrm{~m})$ and storm surge $(2-5)$ noted for storm events (Harmelin-Vivien, 1994), it is unsurprising the midHolocene highstand had minimal impact on the sensitivity of our site to tropical cyclone strikes.

In contrast, the deposition of fine sand $(250-63 \mu \mathrm{m})$ relative to the silt/clay fraction in the lagoon can be closely tied to sea level changes over at least the past $3000 \mathrm{yrs}$ (Fig. 4A). The enrichment in fine sands over the past 1500 yrs likely is induced by lower sea level enhancing the transport of material from the reef flat by shallow water waves, similar to the dynamics noted for tidal flats (Fagherazzi et al., 2006). This effect may also be enhanced by increased advection of silt/clay-sized sediments in the suspended load during periods of higher sea level. Further, the gradual decrease in fine sand accumulation earlier in the record (50003000 yrs BP) may occur as the surrounding barrier reef 'catches-up' with sea level, as is noted for reefs around French Polynesia (Montaggioni, 2005). Remnant submerged ( $\sim-10 \mathrm{mbsl})$ karst topography oceanward of our site indicates reef accretion and erosion has infilled substantial areas of the reef flat since deglacial flooding, possibly syphoning off the source of sand to the lagoon. However, the impact of changes in reef morphology seems restricted to the fine sand fraction as changes in overall sedimentation rate and percent coarse appear largely independent (Fig. 4).

This does not appear to be the case for the coral conglomerates and reef block deposits. Instead, there is a sharp decrease in the number of deposits after 1000 yrs BP (Fig. 5B), coincident with the end of the Mid-Holocene Highstand (Fig. 4). Although our overwash record suggest $1000-500$ yrs BP was a period of relatively high storm activity in French Polynesia, conglomerate or reef block deposits from these events may be difficult to identify in the modern surf zone. In contrast, many of barrier reef islands (motu) are constructed from Mid-Holocene Highstand ( $\mathrm{MHH}$ ) coral ruble and relatively speaking, can be readily sampled.

Although tsunamis regularly impact French Polynesia, the geometry of our site, historic records and spatial orientation of coral conglomerate deposits suggest most are storm derived. Our site, being located on the western side of the lagoon separating Tahaa and Raiatea, is sheltered from tsunamis originating from the North, East and South. Only those tsunamis generated along the Tonga trench are likely to significantly impact our study site. A summary of tsunamis known to have hit French Polynesia by Sladen et al. (2007) suggest the Society Islands have not been impacted from the west within the historic interval despite several large earthquakes ( $>8$, Richter Scale) along the Tonga Trench (Okal et al., 2004) and at least one major tsunami over this period. In contrast, most modern storm activity in the central South Pacific occurs to the west of our site (Fig. 1A). Even instrumentally observed tsunamis that have impacted French Polynesia from other orientations have generated relatively small wave heights $(<2 \mathrm{~m}$ Sladen et al., 2007), likely owing to the steep outer slopes of most barrier-reef fringed islands. This compares with maximum observed storm surge of $4 \mathrm{~m}$ and wave heights of up to $12 \mathrm{~m}$ during the 1982/1983 tropical cyclone season in French Polynesia alone (Harmelin-Vivien and Laboute, 1986). On longer timescales, the record of coral conglomerate and reef block deposits (Table 1) suggest most of the coarse deposits we observe are likely storm derived. In general, we do not observe synchronous deposition of conglomerates or reef blocks across a large number of islands, all with the same orientation to the sea as would be expected from a large tsunami. Instead, these results are more consistent with storms impacting individual islands at different times from various directions. Although it is not possible to rule out a tsunami origin for any given overwash deposits in our record, on the basis of this analysis and the observed correspondence with known cyclones impacting our site, we interpret most to be storm generated.

\subsection{Comparison to other records}

Currently, no continuous multi-millennial records of tropical cyclone activity exists for the central South Pacific, however, coral conglomerate, reef block deposits and beach ridges from the region (Fig. 5B) provide key insight into past local and basin-wide tropical cyclone activity. These data indicate that the out-of-phase behavior between tropical cyclone activity in the western and central South Pacific that is seen today (Revell and Goulter, 1986; Hastings, 1990) may have persisted since at least the mid-Holocene. The slight offsets ( 300 yrs) between the Central Pacific and Northeastern Australian records may be explained by the methods and substrate dated for each. The beach ridges were dated using OSL (Forsyth et al., 2010, 2012; Nott and Forsyth, 2012) and therefore should 
give the age of formation. On the other hand, radiocarbon ages of coral conglomerates or reef blocks (Table 1) give the date the coral grew which may predate deposition. At the same time, the residence of old coral material on the barrier is likely limited by reef processes such as bio and wave erosion which work to export it offshore (or into the lagoon) or vertical accretion which would incorporate the material into the reef framework.

A larger coordinated pattern of tropical cyclone activity also emerges between the central South Pacific and other tropical cyclone basins (Fig. 5A-F). A record of landfalling typhoons from two coastal lakes in Kamikoshiki, Japan, indicates the central South Pacific (Tahaa) and North Pacific may be out-of-phase on millennia timescales. This is unexpected given the correlation of modern storm events with periods of El Niño at both sites (e.g. Revell and Goulter, 1986; Wang and Chan, 2002). In contrast, the increased storm activity around French Polynesia between 2900 and 500 yrs BP is more consistent with observations from the Bahamas (Toomey et al., 2013) and Puerto Rico (Donnelly and Woodruff, 2007) over this same interval. A comparison of high-energy event layers in TAH VC3 and VC4 with hydrologic records from Ecuador (Fig. 5F, Moy et al., 2002) and elsewhere in the Pacific (Conroy et al., 2008; Tierney et al., 2012) indicates there may also be a link between ENSO and tropical cyclone activity in the Pacific (Fig. 5A,F). Many of the largest events (2500-1000 yrs BP) in TAH VC4 seem to coincide with periods of decreased runoff in the Eastern Pacific and inferred El Niño frequency (Moy et al., 2002; Conroy et al., 2008). Although the exact evolution of ENSO over the Holocene remains controversial (Cobb et al., 2013), the observed oscillation of storm activity in the central and western South Pacific (Fig. 5B) is suggestive of a regional cyclone dependence on an ENSO-like forcing. However, higher resolution and a wider geographic distribution of both ENSO and tropical cyclone records are needed to statistically test the connection between tropical Pacific dynamics and storm activity across the various basins.

Another explanation for the observed anti-phase behavior between the central South Pacific (active) and North Atlantic (inactive) between 5000 and 3800 yrs BP may be precession driven insolation changes between the hemispheres. Increased cyclone activity prior to 3800 yrs BP in French Polynesia may be related to lower storm season insolation. Work by Korty et al. (2012) suggests precession-related decreases in storm season insolation may have led to a stronger ocean-atmosphere thermal gradient and increased potential intensity in the South Pacific. Precession would be expected to have the opposite effect on storm potential intensity in the North Atlantic.

\section{Conclusions}

We have reconstructed a 5000-yr record of overwash deposition, likely dominantly by cyclones, from Tahaa, French Polynesia. This record gives us insight into the complex history of cyclone activity in the central South Pacific using new techniques for overwash reconstruction in barrier-reef settings. We find strong coherence between recent coarse-grained deposits and observed events. Coral conglomerate or reef block deposits from Tahaa and nearby islands date closely to several of the older deposits in our records. Together, this suggests high energy event layers deposited in the lagoon are storm derived. In this framework, we can begin to understand long-term patterns in 'storminess' as well as how cyclone activity is influenced by other climate parameters.

Reconstructions from Tahaa highlight a period of higher coarse overwash flux between approximately 2900 and 500 yrs BP, compared with the modern, and an earlier active period occurs between 5000 and 3800 yrs BP. Over the later interval (2900-500 yrs
BP), higher than background storm activity is observed near the Bahamas while a general decrease in storm activity near Japan is observed. Central South Pacific and North Atlantic tropical cyclones diverge during the earlier active interval (5000-3800 yrs BP), possibly driven by orbital changes in storm season insolation. These relationships are unexpected given modern observations that indicate tropical cyclone activity in the North Atlantic and central South Pacific increase during opposite ENSO phases. The Tahaa cyclone reconstruction also highlights a period of relative quiescence around French Polynesia today and likewise, the potential risk in the future should levels of activity increase to those observed prior to $\sim 500 \mathrm{yrs}$ BP. Cumulatively, our results reveal the high potential of back-reef settings for recording overwash but also the gaps in our understanding of long-term tropical cyclone patterns.

\section{Acknowledgments}

This work was supported through the WHOI Coastal Ocean and Ocean and Climate Change Institutes. We also thank the Sea Education Association and the captain and crew of the SSV Robert C. Seamans. Skye Moret, Michaeline Nelson, Rebecca Sorel, Stephanie Madsen, Phil Lane, Andrea Hawks, Andrew Ashton assisted with field work and laboratory analyses. We also thank an anonymous reviewer for their thoughtful comments.

\section{References}

Appleby, P.G., Oldfield, F., 1978. The calculation of lead-210 dates assuming a constant rate of supply of unsupported ${ }^{210} \mathrm{~Pb}$ to the sediment. CATENA $5,1-8$. Appleby, P.G., Oldfield, F., 1983. The assessment of ${ }^{210} \mathrm{~Pb}$ data from sites with varying sediment accumulation rates. Hydrobiologia 103, 29-35.

Basher, R.E., Zheng, X., 1995. Tropical cyclones in the southwest Pacific: spatial patterns and relationships to southern oscillation and sea surface temperature. Journal of Climate 8, 1249-1260.

Blumenstock, D.I., Fosberg, F., Johnson, C.G., 1961. The re-survey of typhoon effects on Jaluit Atoll in the Marshall Islands. Nature 189, 618-620.

Blumenstock, D.I. 1958. Typhoon effects at Jaluit atoll in the Marshall Islands. Nature 182, 1267-1269.

Chevalier, J., Salvat, B., 1976. Etude geomorphologique de l'atoll ferme de Taiaro. In: Cah Pac., vol. 19, pp. 169-201.

Clement, A.C., Seager, R. Cane, M. A. 2000. Suppression of El Niño during the midHolocene by changes in the Earth's Orbit. Paleoceanography 15, 731-737.

Cobb, K.M., Westphal, N., Sayani, H.R., Watson, J.T., Di Lorenzo, E., Cheng, H. Edwards, R., Charles, C.D., 2013. Highly variable El Niño-Southern Oscillation throughout the Holocene. Science 339, 67-70.

Conroy, J.L., Overpeck, J.T., Cole, J.E., Shanahan, T.M., Steinitz-Kannan, M., 2008 Holocene changes in eastern tropical Pacific climate inferred from a Galápagos lake sediment record. Quaternary Science Reviews 27, 1166-1180.

Curray, J.R., Shepard, F.P., Veeh, H.H., 1970. Late Quaternary sea-level studies in Micronesia: CARMARSEL Expedition. Geological Society of America Bulletin 81, $1865-1880$.

Delibrias, G., Guillier, M.T., Labeyrie, J., 1969. Gif natural radiocarbon measurements III. Radiocarbon 11 (2), 327-344.

Donnelly, J.P., Woodruff, J.D., 2007. Intense hurricane activity over the past 5,000 years controlled by El Nino and the West African monsoon. Nature 447, 465-468.

Donnelly J.P. Roll S. Wengren, M Butler J Lederer R, Webb, T 2001 Sedimentary evidence of intense hurricane strikes from New Jersey. Geology 29, 615-618.

evidence of intense hurricane strikes from New Jersey. Geology 29, 615-618.

agherazzi, S., Carniello, L., D’Alpaos, L., Defina, A., 2006. Critical bifurcation of shallow microtidal landforms in tidal flats and

Forsyth, A.J., Nott, J., Bateman, M.D., 2010. Beach ridge plain evidence of a variable late-Holocene tropical cyclone climate, North Queensland, Australia. Palaelate-Holocene tropical cyclone climate, North Queensland,
ogeography, Palaeoclimatology, Palaeoecology 297, 707-716

Forsyth, A.J., Nott, J., Bateman, M.D., Beaman, R.J., 2012. Juxtaposed beach ridges and foredunes within a ridge plain-Wonga Beach, northeast Australia. Marine Geology 307-310, 111-116.

Gischler, E., 2011. Sedimentary facies of Bora Bora, Darwin's type barrier reef (Society Islands, south Pacific): the unexpected occurrence of non-skeletal grain Journal of Sedimentary Research 81, 1-17.

Gleason, M., 1993. Effects of disturbance on coral communities: bleaching in Moorea, French Polynesia. Coral Reefs 12, 193-201.

Glynn, P.W., 1984. Widespread coral mortality and the 1982-83 El Nino warming event. Environmental Conservation 11, 133-146.

Grossman, E., Fletcher III, C., Richmond, B., 1998. The Holocene sea-level highstand in the equatorial Pacific: analysis of the insular paleosea-level database. Coral Reefs $17,309-327$. 
Guilcher, A., 1969. Les Récifs et lagons coralliens de Mopelia et de Bora-Bora (îles de la Société): et quelques autres récifs et lagons de comparaison (Tahiti, Scilly, Tuamotu occidentales); morphologie, sédimentologie, fonctionnement hydrologique, vol. 38. IRD Editions.

Guillou, H., Maury, R.C., Blais, S., Cotten, J., Legendre, C., Guille, G., Caroff, M., 2005. Age progression along the Society hotspot chain (French Polynesia) based on new unspiked K-Ar ages. Bulletin de la Societe Géologique de France 176, 135-150.

Harmelin-Vivien, M.L., Laboute, P., 1986. Catastrophic impact of hurricanes on atol outer reef slopes in the Tuamotu (French Polynesia). Coral Reefs 5, 55-62.

Harmelin-Vivien, M.L., 1994. The effects of storms and cyclones on coral reefs: a review. Journal of Coastal Research, 211-231.

Harris, P., Fichez, R., Fernandez, J.-M., Golterman, H., Badie, C., 2001. Using geochronology to reconstruct the evolution of particulate phosphorus inputs during the

Hastings, P. . 1990. Pouthern oscillation influences on . Oceanologica Acta 24, $1-10$. the Australian/south-west Pacific region. International Journal of Climatology the Australian $291-298$.

Hubbs, C.L., Bien, G.S., 2006. La Jolla natural radiocarbon measurements V.

Huybers, P., 2012. inso.m. http://www.people.fas.harvard.edu/ phuybers/Mfiles/ Toolbox/.

Kench, P.S., Brander, R.W., 2006. Wave processes on coral reef flats: implications for reef geomorphology using Australian case studies. Journal of Coastal Research, 209-223.

Knapp, K.R., Kruk, M.C., Levinson, D.H., Diamond, H.J., Neumann, C.J., 2010. The International Best Track Archive for Climate Stewardship (IBTrACS). Bulletin of the American Meteorological Society 91, 363-376.

Korty, R.L., Camargo, S.J., Galewsky, J., 2012. Variations in tropical cyclone genesis factors in simulations of the Holocene epoch. Journal of Climate 25, 8196-8211.

Lane, P., Donnelly, J.P., Woodruff, J.D., Hawkes, A.D., 2011. A decadally-resolved paleohurricane record archived in the late Holocene sediments of a Florid sinkhole. Marine Geology 287, 14-30.

Liu, K.-b., Fearn, M.L., 1993. Lake-sediment record of late Holocene hurricane activities from coastal Alabama. Geology 21, 793-796.

McKee, E.D., 1959. Storm sediments on a Pacific atoll. Journal of Sedimentary Research 29.

Montaggioni, L., Pirazzoli, P. 1984. The significance of exposed coral conglomerates from French Polynesia (Pacific Ocean) as indicators of recent relative sea-level changes. Coral Reefs $3(1), 29-42$

Montaggioni, L.F., 2005. History of Indo-Pacific coral reef systems since the last glaciation: development patterns and controlling factors. Earth-Science Reviews $71,1-75$.

Moy, C.M., Seltzer, G.O., Rodbell, D.T., Anderson, D.M., 2002. Variability of El Nino/ Southern Oscillation activity at millennial timescales during the Holocene epoch. Nature 420, 162-165.

Nott, J., Forsyth, A., 2012. Punctuated global tropical cyclone activity over the past 5,000 years. Geophysical Research Letters 39, L14703.

Okal, E.A., Borrero, J., Synolakis, C.E., 2004. The earthquake and tsunami of 1865 November 17: evidence for far-field tsunami hazard from Tonga. Geophysical Journal International 157, 164-174.
Pirazzoli, P.A., Montaggioni, L.F., 1986. Late Holocene sea-level changes in the northwest Tuamotu Islands, French Polynesia. Quaternary Research 25 (3), $350-368$.

Pirazzoli, P., Montaggioni, L., 1987. Les îles Gambier et l'atoll de Temöe (Polynésie française): anciennes lignes de rivage et comportement géodynamique. Géodynamique $2(1), 13-25$

Pirazzoli, P., Montaggioni, L., 1988. Holocene sea-level changes in French Polynesia. Palaeogeography, Palaeoclimatology, Palaeoecology 68 (2), 153-175.

Pirazzoli, P.A., et al., 1987. Late Holocene sea levels and coral reef development in Vahitahi Atoll, eastern Tuamotu Islands, Pacific Ocean. Marine Geology $76(0)$ 105-116.

Pirazzoli, P., et al., 1988. Late Holocene sea level indicators from twelve atolls in the central and eastern Tuamotus (Pacific Ocean). Coral Reefs 7 (2), 57-68.

Pirazzoli, P., 1985a. Sea-level changes in Rangiroa. In: Ricard, M. (Ed.), Rangiroa Atoll. Fifth International Coral Reef Congress, pp. 192-198.

Pirazzoli, P., 1985b. Leeward islands, Maupiti, Tupai, Bora Bora, Huahine, Society archipelago: 5th International Coral Reef Symposium, Tahiti. In: Proceedings.

Pirazzoli, P.A., 1987. A reconnaissance and geomorphological survey of Temoe atoll, Gambier Islands (South Pacific). Journal of Coastal Research, 307-323.

Reimer, P.J., Baillie, M.G.L., Bard, E., Bayliss, A., Beck, J.W., Blackwell, P.G., Ramsey, C.B., Buck, C.E., Burr, G.S., Edwards, R.L., 2009. IntCal09 and Marine09 radiocarbon age calibration curves, $0-50,000$ years cal BP.

Revell, C.G., Goulter, S.W., 1986. South Pacific tropical cyclones and the Southern Oscillation. Monthly Weather Review 114, 1138-1145.

Scileppi, E., Donnelly, J.P., 2007. Sedimentary Evidence of Hurricane Strikes in Western Long Island vol. 8. Geochem. Geophys. Geosyst, New York, p. Q06011.

Sladen, A., Hébert, H., Schindelé, F., Reymond, D., 2007. Evaluation of far-field tsunami hazard in French Polynesia based on historical data and numerical simulations. Natural Hazards and Earth System Science 7, 195-206.

Teissier, R., 1982. Les Cyclones en Polynésie Française: 1878, 1903, 1905, 1906. Société des études océaniennes.

Tierney, J., Oppo, D., LeGrande, A., Huang, Y., Rosenthal, Y., Linsley, B., 2012. The influence of Indian Ocean atmospheric circulation on Warm Pool hydroclimate during the Holocene Epoch. Journal of Geophysical Research 117.

Toomey, M.R., Curry, W.B., Donnelly, J.P., Hengstum, P.J., 2013. Reconstructing 7000 years of North Atlantic hurricane variability using deep-sea sediment cores from the western Great Bahama Bank. Paleoceanography 28 (1), cores $31-41$.

von Reden, K.F., Roberts, M.L., Burton, J.R., Beaupre, S.R., 2012. Optimizing a microwave gas ion source for continuous-flow accelerator mass spectrometry. Review of Scientific Instruments 83, 02B304-304

Wang, B., Chan, J.C.L., 2002. How strong ENSO events affect tropical storm activity over the western North Pacific*. Journal of Climate 15, 1643-1658.

Woodroffe, C., et al., 1990. Holocene emergence in the Cook islands, South Pacific Coral Reefs $9(1), 31-39$.

Woodruff, J.D., Donnelly, J.P., Okusu, A., 2009. Exploring typhoon variability over the mid-to-late Holocene: evidence of extreme coastal flooding from Kamikoshiki, Japan. Quaternary Science Reviews 28, 1774-1785. 
CHAPTER 4: Coupled hydrographic and tropical cyclone variability in the central South Pacific over the late-Holocene

Advisors: Jeff Donnelly and Jess Tierney

\begin{abstract}
The El Niño-Southern Oscillation (ENSO) is the main driver of inter-annual climatic variability in the tropical Pacific and has profound effects on the people living within its margins and beyond. ENSO has been linked to remote atmospheric phenomena such as the East Asian Monsoon and tropical cyclone activity in the Pacific and North Atlantic, and hypothesized changes in its behavior in response to anthropogenic warming hold global implications (Guilyardi et al., 2009). Some of the strongest ENSO driven sea surface temperature and precipitation variability is seen in the Central Pacific but it has few conventional sites (upland lakes etc.) typically used for multi-millennial proxy records, greatly limiting our ability to understand how tropical Pacific climate has changed in the past and project how it might respond to a warming world. Here we use a proxy runoff record from Apu Bay on the island of Tahaa, French Polynesia to document rainfall intensification in the Central Pacific over the late Holocene. Proxy records of tropical cyclone activity from Tahaa and elsewhere in the central Pacific suggest major storm activity was significantly higher between 2060-1250 yrs BP and is anti-correlated with the changes in precipitation we observe. Additionally, we find a period of increased runoff at Tahaa (900-650yrs BP) is synchronous with migration by early Polynesians into the Central Pacific (Wilmshurst et al., 2011) and suggests the development of El Niñolike wind reversals at this time may have been a key catalyst in their expansion.
\end{abstract}




\section{Main Text}

Proxy records of past hydrologic variability (Conroy et al., 2008; Moy et al., 2002; Sachs et al., 2009; Tierney et al., 2012) demonstrate that precipitation patterns across the Pacific have varied on centennial to millennial time scales over the mid-late Holocene. In general, records show increased rainfall variability since 4000 yrs BP (Conroy et al., 2008; Donders et al., 2008; Makou et al., 2010; Moy et al., 2002) but disagree on the detailed behavior of Pacific Walker-Circulation since the mid-Holocene.

Back-reef lagoons surrounding high volcanic islands in the Central Pacific may offer yet unexplored records of Pacific climate variability. On many reef enclosed islands, deep lagoons ( $>30 \mathrm{~m})$ occupy drowned paleo river valleys (Purdy and Winterer, 2006; Stark and Dapples, 1941) and preserve terrestrial sediments (Gischler, 2011) shed by nearby slopes during runoff events. Such sites are widespread and have high potential as valuable paleoclimate archives. Previous coring and geophysical efforts indicate that deposition in back barrier reef lagoons has been fast (up to $6.9 \mathrm{~mm} / \mathrm{yr}$ ) (Montaggioni, 2005) and spans much of the Holocene as well as previous interglacials (Le Roy et al., 2008). Most lagoons are readily accessible to large oceanographic vessels which would likely be important for recovering such expanded pre-Holocene sequences.

In January 2009 we collected a vibra-core from Apu Bay on the island of Tahaa $\left(17^{\circ} \mathrm{S}\right.$ $151^{\circ} \mathrm{W}$ ), French Polynesia, $230 \mathrm{~km}$ northeast of Tahiti (FIG. 1). Tahaa is a highly eroded volcanic ocean island, formed 2-3 myrs ago (Guillou et al., 2005) as part of the Society Islands hotspot chain. Apu Bay is thought to be a drowned ( 40m deep), glacial-age river drainage (Stark and Dapples, 1941), incised into the volcanic upland and flanked on three sides by steep $\left(\sim 25 \%\right.$ grade) ridges. Core TAH VC10 $\left(16.6686^{\circ} \mathrm{S}, 151.4918^{\circ} \mathrm{W}\right)$ is located in the center of the bay (FIG. 1A), 500 m from the shore. Seismic surveying at the site (FIG. 1D) and ${ }^{14} \mathrm{C}$ dating of sediments (Appendix 2) indicates a large, relatively 
uniform sedimentary pile (shaded blue) has accumulated in Apu Bay since deglacial sea level inundation.

Tahaa is located on the edge of the South Pacific Convergence Zone (SPCZ) trough and experiences major seasonal as well as ENSO related changes in precipitation (FIG. 2A). El Niño events are associated with eastward displacement of the SPCZ (Widlansky et al., 2011) and increased precipitation at Tahaa. A rain-gauge record from Tahiti (230km SE of Tahaa) shows a 34\% increase in precipitation during months when the Southern Oscillation Index (SOI; UCAR), the sea level pressure between Tahiti and Darwin (Australia), was negative (El Niño) compared with months that SOI was positive (La Niña). The difference was mostly seen during the austral summer (JFM) when, on average, it resulted in nearly $100 \mathrm{~mm} /$ month more precipitation than mean conditions. During the rainiest months in the record, rainfall often exceeded $500 \mathrm{~mm} /$ month above background.

Color changes in the sediment core, seen using reflectance spectrophotometry, indicate that terrestrial material is periodically mobilized from the adjacent volcanic slopes during rainfall events and deposited in the lagoon. Principal component analysis of reflectance peaks suggests that terrestrial weathering products (hematite, oxides) constitute a major component of the sediments. Visible dark streaks in the core coincide with observed increases in oxide concentration. Heavy mineral components typical of ocean island basalts (olivine, pyroxenes) are lacking, likely reflecting transport limitations. The matrix material is made up of carbonate mud, glauconite and organic material likely produced in situ or on the reef (FIG. S1). Coarse material in the cores is dominantly detrital carbonate material, likely swept off nearby fringing reefs during storms. Together, this evidence suggests that soil material (dark layers) is episodically delivered to the lagoon, deposited into sediments that are otherwise dominated by carbonate mud (light grey matrix) and may be used to reconstruct a record of extreme precipitation events back through time. 
In order to estimate the input of terrestrial material downcore we used high-resolution Xray fluorescence (XRF). Core-scanning XRF is ideally suited for this work as it is high resolution, fast and sensitive to relative changes in metals. Sedimentary titanium in particular has been used successfully to infer past changes in runoff (e.g. Haug et al., 2001) as it is not used as a microbial electron acceptor. Previous work in the Society chain documents Ti oxides as significant components of the volcanic basement and soils (Parkes et al., 1992). Comparison of Ti/Ca ratios from discrete soil samples collected on Tahaa and carbonate material taken from the reef flat (FIG. 2C) demonstrates a clear elemental division between these end members. Carbonate reef material is depleted in $\mathrm{Ti}$ whereas terrestrial samples contain little $\mathrm{Ca}$. Therefore, we interpret Ti rich material recovered from Apu Bay (FIG 2, FIG 3B) as terrestrially derived and likely delivered to the lagoon during large runoff events.

The derived record of terrestrial runoff at our site demonstrates a significant correspondence to observed decadal-scale changes in SOI and local rainfall. Of ten thousand potential sedimentation rates (FIG. S1) generated by resampling the uncertainties in our ${ }^{210} \mathrm{~Pb}$ chronology, 78\% (94\%) yield a positive (negative) correlation (Spearman's $\rho$ ) with maximum yearly rainfall (SOI) on decadal timescales (FIG 2D). In general we also observe a large increase in $\mathrm{Ti} / \mathrm{Ca}$ after $1970 \mathrm{AD}$ that corresponds with an observed intensification of negative SOI events over the past 40 years (NCAR-CGD). Likewise, a number of large peaks around $1900 \mathrm{AD}$ are consistent with historic records of several large negative SOI excursions around this time. Thus, downcore changes in $\mathrm{Ti} / \mathrm{Ca}$ are likely linked to changes in precipitation providing essential data illuminating late Holocene tropical Central Pacific climate dynamics.

The record of runoff from Tahaa (FIG. 3B) suggests that background precipitation has intensified over the late Holocene (2000 yrs BP to present) consistent with records elsewhere in the Pacific. Work by Tierney et al. 2010 using $\delta D_{\text {wax }}$ from marine sediments recovered from the Makassar Straits indicate a similar increase in rainfall has occurred 
over this interval within the Indo-Pacific Warm Pool (IPWP; FIG 3A). Likewise, a gradual increase in the silt fraction and inferred water-level of El Junco lake, Galapagos, beginning around 2000 yrs BP also suggests (Conroy et al., 2008) increased background precipitation in the Eastern Pacific beginning around 2000 yrs BP. Together, these records indicate a basin-wide intensification of the background hydrologic cycle over the last 2000 years potentially driven by precession. Warmer austral summers may have resulted in a more southward mean position of the ITCZ and a more northeasterly positioning of the SPCZ. Temperature differences between the hemispheres may also explain observation of increased precipitation at SH sites (Conroy et al., 2008; Moy et al., 2002; Sachs et al., 2009; Tierney et al., 2010) during the Little Ice Age. We observe changes in high frequency ( $<100 \mathrm{yrs}$ ) variability in TAH VC10 (FIG. 4) but it increases somewhat abruptly around 900 yrs BP and remains elevated through to the present. We find that short-term event deposition is highest between 900 and $650 \mathrm{yrs}$ BP consistent with records from the Eastern Equatorial Pacific (Conroy et al., 2008; Moy et al., 2002).

Grain-size changes recorded in TAH VC10 also suggest a coordinated pattern of central South Pacific storm activity likely related to the changes in tropical Pacific atmospheric dynamics noted above. Coarse deposits in TAH VC10 (e.g. 2060-1875, 1740-1580 and 1350-1250 yrs BP) match well with large overwash events in previously developed backbarrier reef storm records from Tahaa (TAH VC3/4) and dated reef-block/conglomerate deposits from islands across the central South Pacific (Toomey et al., 2013). Given that our site is relatively sheltered (FIG. 1) we expect that grain-size changes in TAH VC10 mostly reflect changes in major storm frequency. The transition to lower major storm activity after 1250 yrs BP is not readily explained by falling sea level at this time given that background grain-size $(63-250 \mu \mathrm{m})$ in TAH VC10 increased over the late Holocene (FIG S2), similar to the results from TAH VC3/4 (Toomey et al., 2013). We evaluated the correlation between $\mathrm{Ti} / \mathrm{Ca}$ and grain-size against 10000 time-series with the same spectral properties as our data (Anchukaitis, 2008; Ebisuzaki, 1997) and found a significant $(<0.05)$ negative (Pearson's $r=-0.24)$ relationship between precipitation and 
storm activity ( $1 \mathrm{~cm}, \sim 5 \mathrm{yr}$; interpolated and log transformed) over the late Holocene. This contrasts sharply with modern observations which show a positive correlation between rainfall and storm activity across French Polynesia driven largely by migrations of the SPCZ during ENSO events (Revell and Goulter, 1986; Toomey et al., 2013). Historical observations may therefore be insufficient for assessing the potential risk of central Pacific islands to tropical cyclone strikes as climate evolves over the coming decades.

Periods of increased rainfall and decreased tropical cyclone activity near Tahaa also match closely with archeological evidence of punctuated migrations into the Central Pacific by early Polynesians (French Polynesia, 925-829 yrs BP, Remote Polynesia (i.e. Hawaii, New Zealand, Rapa Nui) 750-660 yrs BP; Wilmshurst et al., 2011). Many hypotheses have been suggested to resolve the 'Long-Pause', a 1000 yr gap between Polynesian expansion into Western Polynesia and their eventual colonization of French Polynesia/Remote Oceania, including opportunistic voyaging, advances in seafaring/navigation and simply an incomplete archeological record (Kirch, 2000). However, our data supports previous authors' (Anderson et al., 2006) position that El Niño-like weakening or reversal of easterlies may have allowed Polynesian to sail east. The onset of increased high frequency events between 900 and $650 \mathrm{yrs}$ BP may signal just these sorts of wind reversals and provides compelling evidence that Polynesian expansion may have at least in part been enabled by climate variations. Indeed, decreased tropical cyclone activity in French Polynesia over the past 1000 years may have also worked to increase the odds of success for long distance Polynesian voyaging.

Although wind reversals may have provided a means of migration, climate driven deterioration of island ecosystems in the Western Pacific may have actually pushed Polynesian expansion into the Central Pacific. Inferred increases in rainfall variability and eastward shifts of the SPZC since 900 yrs BP may have worked to lower island carrying capacity in the Western Pacific and push Polynesian expansion. Likewise, the coordinated restructuring of Pacific precipitation patterns we observe likely had a 
profound impact on agriculture and societies around the world. Back-reef sedimentary records provide a unique opportunity to fill major gaps in our understanding of past changes in tropical Pacific dynamics and ultimately, will lead to better forecasting of how ENSO-related precipitation patterns (and therefore society) may evolve in a warming world.

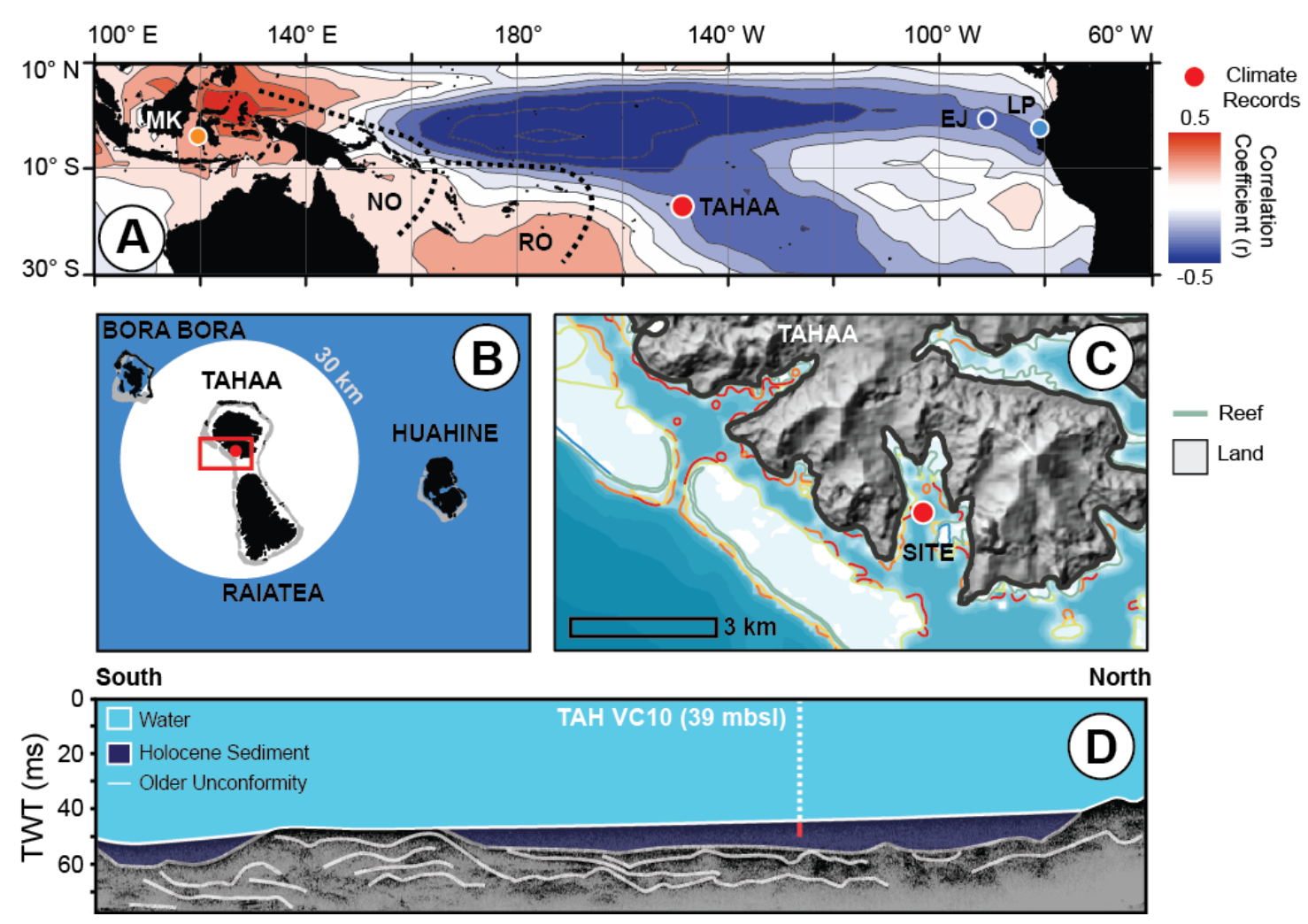

Figure 1. ENSO modulated patterns in Pacific precipitation, site map and core locations. (A) Map showing correlation (Pearson's Product-Moment 'r') of satellite (CMAP) observed precipitation with SOI (UCAR) over the past 30 years (1979-2009 AD). Circles indicate locations of climate records used in FIG.3: Makassar Straits (MK, orange), Tahaa (red), Laguna Playa Grande (LP, light blue) and El Junco (EJ, dark blue). Dotted black lines define Near Oceania (NO) and Remote Oceania (RO). (B) Location of Tahaa relative to other islands in the Society Islands Chain. (C) Topographic (Aster 30m 
resolution) and bathymetric (Admiralty chart \#1103) map of southwestern Tahaa centered on Apu Bay, our coring site. (D) Seismic trace running north-south through Apu Bay which indicates that a large wedge of Holocene sediment as well as several older reflectors. The location of TAH VC10 is indicated by a white dashed line.
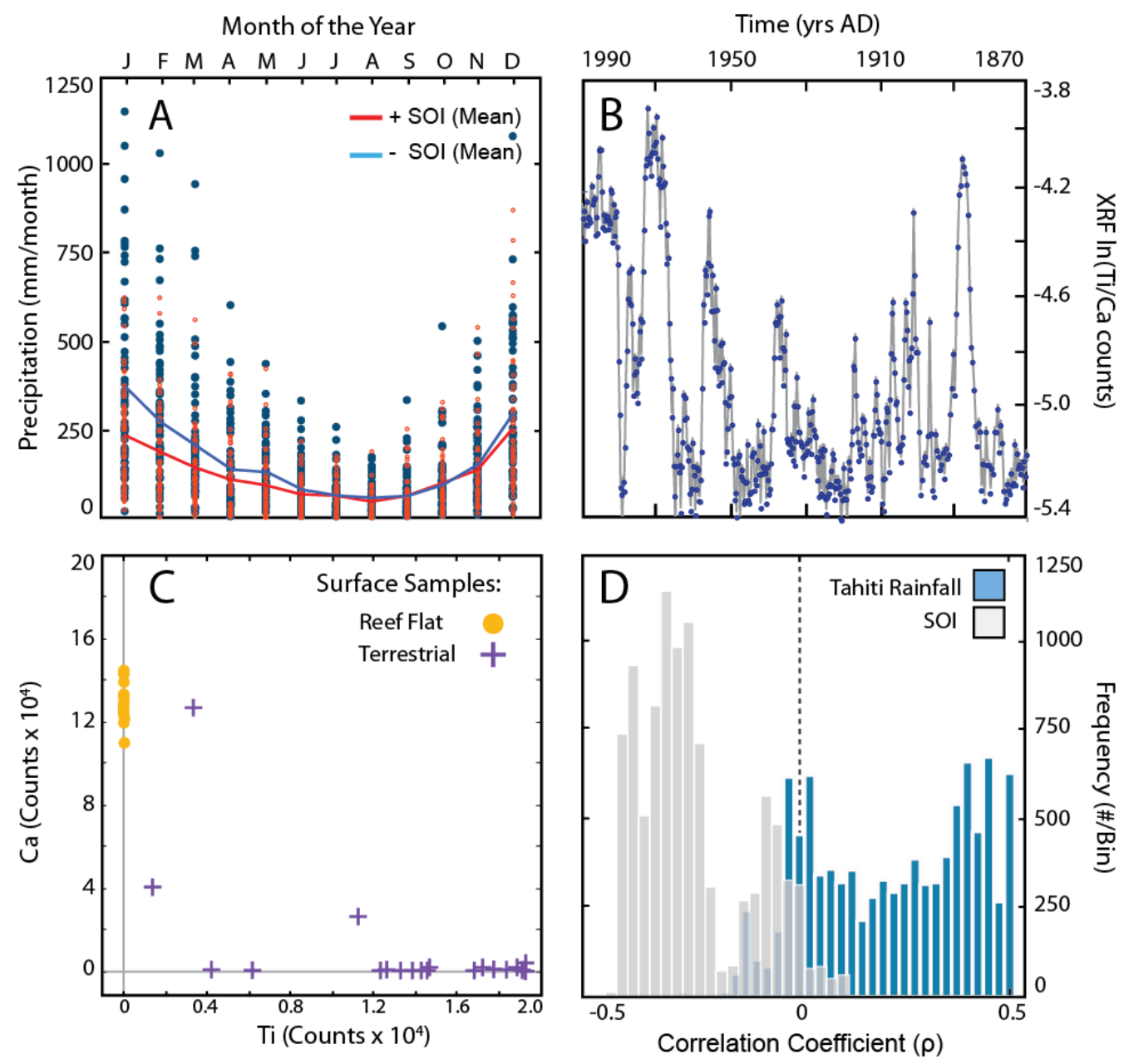

Figure 2. (A) Monthly precipitation observed for the island of Tahiti (230 km SE of Tahaa) (1879-2010 AD). Positive SOI months are shown in orange while negative SOI months are highlighted in blue. Monthly mean values for each phase are given by lines of 
the same colors. (B) Ti/Ca ratio for coretop of TAH VC10 for median modeled sedimentation rate. (C) XRF Ti and Ca counts for discrete samples collected from onshore the volcanic island (purple cross) and reef flat (orange dot). (D) Spearman correlation between Tahaa runoff proxy, Tahiti rainfall (max annual) and SOI (10yr Gaussian filtered) for range of modeled sedimentation rates (FIG. S1).

Figure 3. Compilation of Tropical Pacific climate records for the mid-late Holocene. (Top) Precipitation records (A) $\delta$ Dwax precipitation proxy records from the Indo-Pacific Warm Pool. Red line shows the record from Tierney (2010) and grey line gives data from Tierney (2012) (B) Ti/Ca ratios over the past 2250 years recorded in sediments from Apu Bay, Tahaa. Black line shows 100yr Gaussian filter of Ti/Ca data (C) A record of red color intensity from Laguna Pallcacocha, Ecuador (Moy et al., 2002). Increased red color intensity is inferred to relate to increased runoff. (D) ENSO driven changes in grain-size changes observed from El Junco Lake, Galapagos (Conroy et al., 2008). (E) Central Pacific cyclone records. Black and gray lines show $250 \mu \mathrm{m}-2 \mathrm{~mm}$ and $>250 \mu \mathrm{m}$ size fraction in TAH VC10, respectively. Purple line shows the number of reef block and coral conglomerate deposits in continuous 250yr windows (Toomey et al., 2013). Light blue highlights give periods of Polynesian expansion (Wilmshurst et al., 2011). 


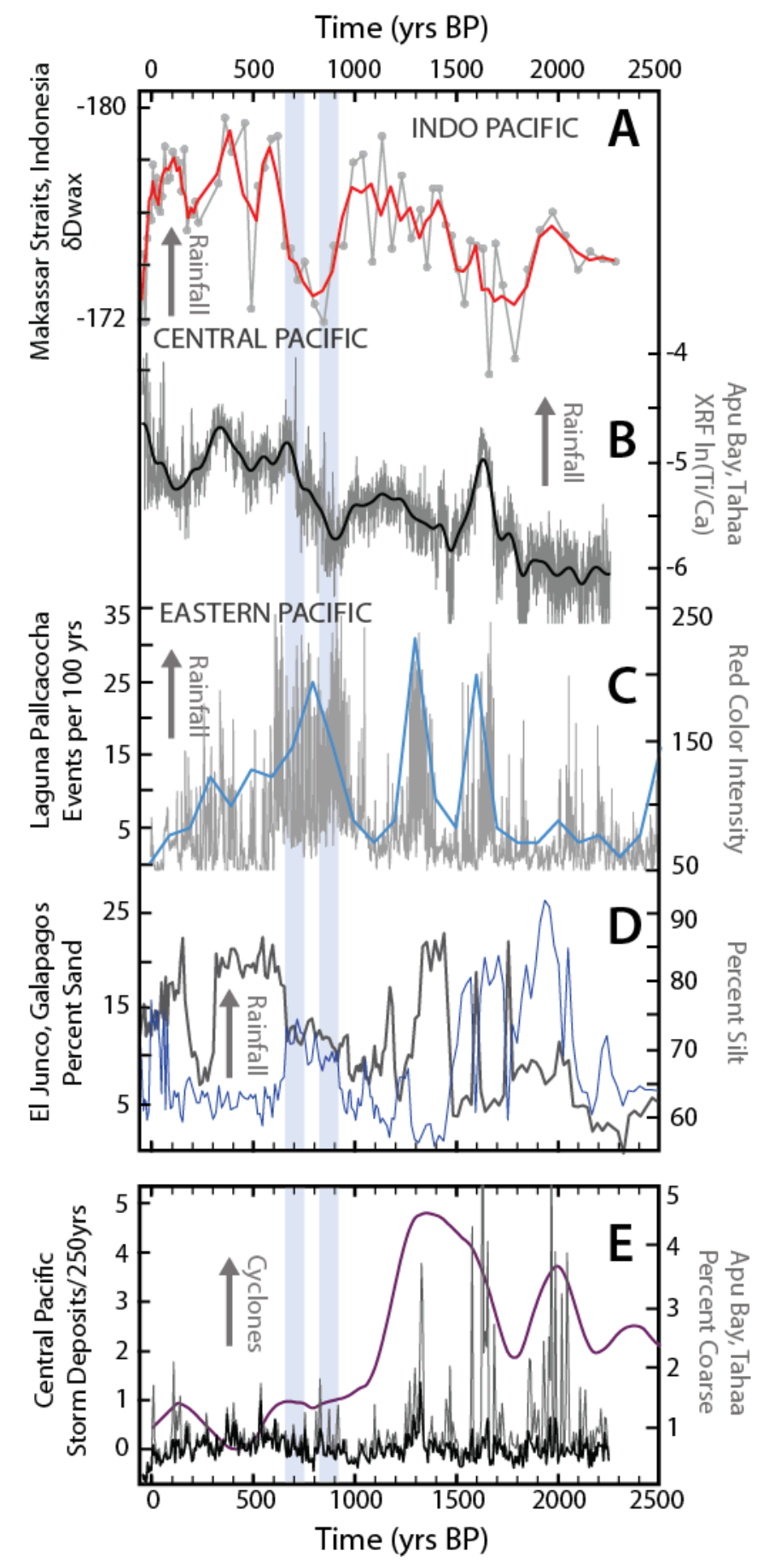




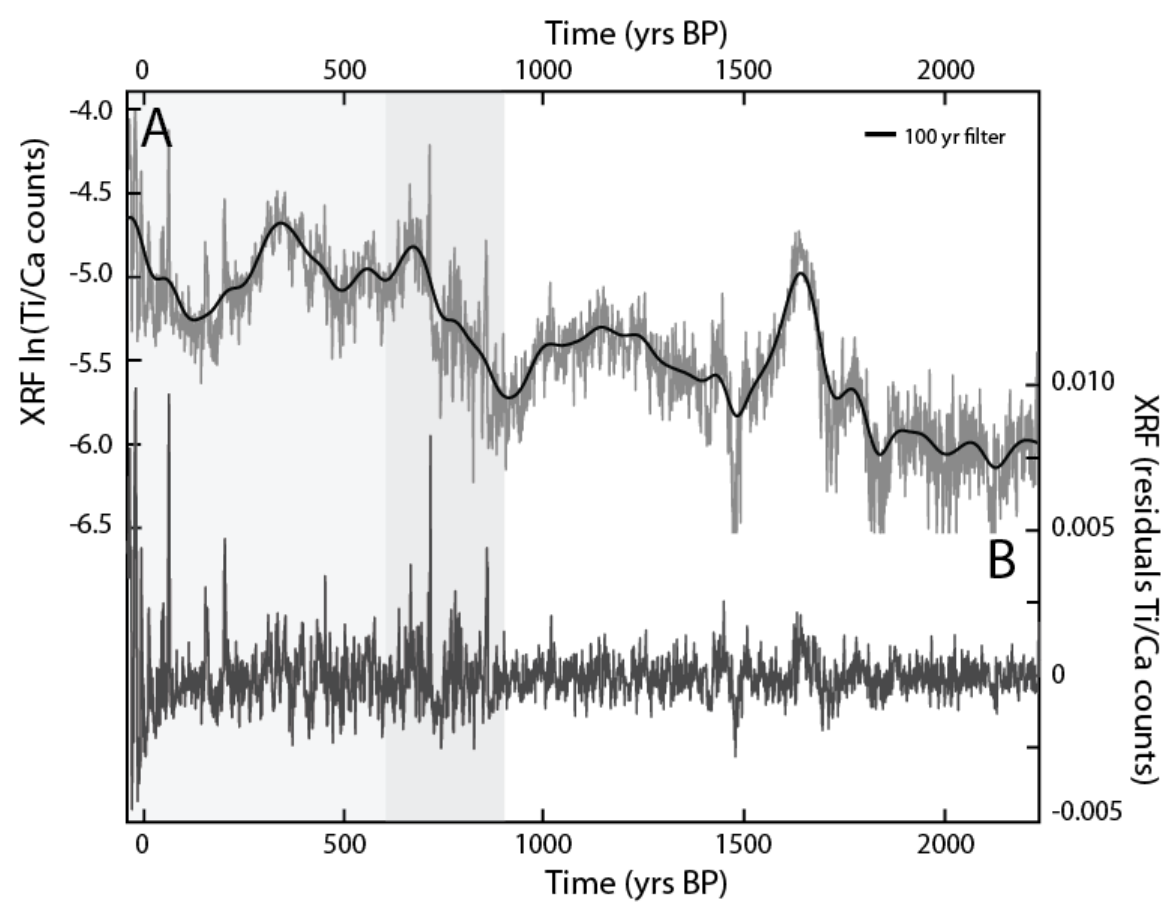

Figure 4. Comparison of short term $(<100 \mathrm{yr})$ and long-term $\mathrm{Ti} / \mathrm{Ca}$ variability in TAH VC10. (A) Raw time-series is given in grey with a 100yr Gaussian filter of the data shown by black line. Note: both are log transformed. (B) Residuals between raw data and $100 y$ r filter.

References:

Anchukaitis, K., 2008. ebisuzaki.m.

Anderson, A., Chappell, J., Gagan, M., Grove, R., 2006. Prehistoric maritime migration in the Pacific islands: an hypothesis of ENSO forcing. The Holocene 16, 1-6.

Conroy, J.L., Overpeck, J.T., Cole, J.E., Shanahan, T.M., Steinitz-Kannan, M., 2008. Holocene changes in eastern tropical Pacific climate inferred from a Galápagos lake sediment record. Quaternary Science Reviews 27, 1166-1180.

Donders, T.H., Wagner-Cremer, F., Visscher, H., 2008. Integration of proxy data and model scenarios for the mid-Holocene onset of modern ENSO variability. Quaternary Science Reviews 27, 571-579. 
Ebisuzaki, W., 1997. A Method to Estimate the Statistical Significance of a Correlation When the Data Are Serially Correlated. Journal of Climate 10, 2147-2153.

Gischler, E., 2011. Sedimentary Facies of Bora Bora, Darwin's Type Barrier Reef (Society Islands, South Pacific): The Unexpected Occurrence of Non-Skeletal Grains. Journal of Sedimentary Research 81, 1-17.

Guillou, H., Maury, R.C., Blais, S., Cotten, J., Legendre, C., Guille, G., Caroff, M., 2005. Age progression along the Society hotspot chain (French Polynesia) based on new unspiked K-Ar ages. Bulletin de la Societe Géologique de France 176, 135-150.

Guilyardi, E., Wittenberg, A., Fedorov, A., Collins, M., Wang, C., Capotondi, A., van Oldenborgh, G.J., Stockdale, T., 2009. Understanding El Nino in Ocean-Atmosphere General Circulation Models: Progress and Challenges. Bulletin of the American Meteorological Society 90, 325-340.

Haug, G.H., Hughen, K.A., Sigman, D.M., Peterson, L.C., Röhl, U., 2001. Southward Migration of the Intertropical Convergence Zone Through the Holocene. Science 293, 1304-1308.

Kirch, P.V., 2000. On the Road of the Winds: An archaeological History of the Pacific Islands before European Contact. University of California Press.

Le Roy, P., Cabioch, G., Monod, B., Lagabrielle, Y., Pelletier, B., Flamand, B., 2008. Late Quaternary history of the Nouméa lagoon (New Caledonia, South West Pacific) as depicted by seismic stratigraphy and multibeam bathymetry: A modern model of tropical rimmed shelf. Palaeogeography, Palaeoclimatology, Palaeoecology 270, 29-45.

Makou, M.C., Eglinton, T.I., Oppo, D.W., Hughen, K.A., 2010. Postglacial changes in El Niño and La Niña behavior. Geology 38, 43-46.

Montaggioni, L.F., 2005. History of Indo-Pacific coral reef systems since the last glaciation: Development patterns and controlling factors. Earth-Science Reviews 71, 175.

Moy, C.M., Seltzer, G.O., Rodbell, D.T., Anderson, D.M., 2002. Variability of El Nino/Southern Oscillation activity at millennial timescales during the Holocene epoch. Nature 420, 162-165.

Parkes, A., Teller, J.T., Flenley, J.R., 1992. Environmental History of the Lake Vaihiria Drainage Basin, Tahiti, French Polynesia. Journal of Biogeography 19, 431-447.

Purdy, E., Winterer, E., 2006. Contradicting Barrier Reef relationships for Darwin's Evolution of reef types. International Journal of Earth Sciences 95, 143-167. 
Revell, C.G., Goulter, S.W., 1986. South Pacific tropical cyclones and the Southern Oscillation. Mon. Weath. Rev 114, 1138-1145.

Sachs, J.P., Sachse, D., Smittenberg, R.H., Zhang, Z., Battisti, D.S., Golubic, S., 2009. Southward movement of the Pacific intertropical convergence zone AD 1400-1850. Nature Geoscience 2, 519-525.

Stark, J.T., Dapples, E.C., 1941. Near shore coral lagoon sediments from Raiatea, Society islands. Journal of Sedimentary Research 11, 21-27.

Tierney, J., Oppo, D., LeGrande, A., Huang, Y., Rosenthal, Y., Linsley, B., 2012. The influence of Indian Ocean atmospheric circulation on Warm Pool hydroclimate during the Holocene Epoch. J. Geophys. Res. 117.

Tierney, J.E., Oppo, D.W., Rosenthal, Y., Russell, J.M., Linsley, B.K., 2010. Coordinated hydrological regimes in the Indo-Pacific region during the past two millennia. Paleoceanography 25, PA1102.

Toomey, M.R., Donnelly, J.P., Woodruff, J.D., 2013. Reconstructing mid-late Holocene cyclone variability in the Central Pacific using sedimentary records from Tahaa, French Polynesia. Quaternary Science Reviews 77, 181-189.

Widlansky, M.J., Webster, P.J., Hoyos, C.D., 2011. On the location and orientation of the South Pacific Convergence Zone. Climate dynamics 36, 561-578.

Wilmshurst, J.M., Hunt, T.L., Lipo, C.P., Anderson, A.J., 2011. High-precision radiocarbon dating shows recent and rapid initial human colonization of East Polynesia. Proceedings of the National Academy of Sciences 108, 1815-1820. 


\title{
CHAPTER 5:
}

\section{Reconstructing 7000 years of North Atlantic hurricane variability using deep-sea sediment cores from the western Great Bahama Bank *}

\begin{abstract}
Available overwash records from coastal barrier systems document significant variability in North Atlantic hurricane activity during the late Holocene. The same climate forcings that may have controlled cyclone activity over this interval (e.g., the West African Monsoon, El Niño-Southern Oscillation (ENSO)) show abrupt changes around 6000 yrs B.P., but most coastal sedimentary records do not span this time period. Establishing longer records is essential for understanding mid-Holocene patterns of storminess and their climatic drivers, which will lead to better forecasting of how climate change over the next century may affect tropical cyclone frequency and intensity. Storms are thought to be an important mechanism for transporting coarse sediment from shallow carbonate platforms to the deep-sea, and bank-edge sediments may offer an unexplored archive of long-term hurricane activity. Here, we develop this new approach, reconstructing more than 7000 years of North Atlantic hurricane variability using coarse-grained deposits in sediment cores from the leeward margin of the Great Bahama Bank. High energy event layers within the resulting archive are (1) broadly correlated throughout an offbank transect of multi-cores, (2) closely matched with historic hurricane events, and (3) synchronous with previous intervals of heightened North Atlantic hurricane activity in overwash reconstructions from Puerto Rico and elsewhere in the Bahamas. Lower storm frequency prior to $4400 \mathrm{yrs}$ B.P. in our records suggests that precession and increased $\mathrm{NH}$ summer insolation may have greatly limited hurricane potential intensity, outweighing weakened ENSO and a stronger West African Monsoon-factors thought to be favorable for hurricane development.
\end{abstract}


*Published as: Toomey, M. R., W. B. Curry, J. P. Donnelly, and P. J. van Hengstum (2013), Reconstructing 7000 years of North Atlantic hurricane variability using deep-sea sediment cores from the western Great Bahama Bank, Paleoceanography, 28(1), 31-41, doi:10.1002/palo.20012.

Reprinted with permission from John Wiley and Sons. 


\title{
Reconstructing 7000 years of North Atlantic hurricane variability using deep-sea sediment cores from the western Great Bahama Bank
}

\author{
Michael R. Toomey, ${ }^{1,2}$ William B. Curry, ${ }^{1}$ Jeffrey P. Donnelly, ${ }^{1}$ and \\ Peter J. van Hengstum ${ }^{1}$ \\ Received 10 July 2012; revised 3 January 2013; accepted 8 January 2013.
}

[1] Available overwash records from coastal barrier systems document significant variability in North Atlantic hurricane activity during the late Holocene. The same climate forcings that may have controlled cyclone activity over this interval (e.g., the West African Monsoon, El Niño-Southern Oscillation (ENSO)) show abrupt changes around 6000 yrs B.P., but most coastal sedimentary records do not span this time period. Establishing longer records is essential for understanding mid-Holocene patterns of storminess and their climatic drivers, which will lead to better forecasting of how climate change over the next century may affect tropical cyclone frequency and intensity. Storms are thought to be an important mechanism for transporting coarse sediment from shallow carbonate platforms to the deep-sea, and bank-edge sediments may offer an unexplored archive of long-term hurricane activity. Here, we develop this new approach, reconstructing more than 7000 years of North Atlantic hurricane variability using coarse-grained deposits in sediment cores from the leeward margin of the Great Bahama Bank. High energy event layers within the resulting archive are (1) broadly correlated throughout an offbank transect of multi-cores, (2) closely matched with historic hurricane events, and (3) synchronous with previous intervals of heightened North Atlantic hurricane activity in overwash reconstructions from Puerto Rico and elsewhere in the Bahamas. Lower storm frequency prior to $4400 \mathrm{yrs}$ B.P. in our records suggests that precession and increased $\mathrm{NH}$ summer insolation may have greatly limited hurricane potential intensity, outweighing weakened ENSO and a stronger West African Monsoon - factors thought to be favorable for hurricane development.

Citation: Toomey, M. R., W. B. Curry, J. P. Donnelly, and P. J. van Hengstum (2013), Reconstructing 7000 years of North Atlantic hurricane variability using deep-sea sediment cores from the western Great Bahama Bank, Paleoceanography 28, doi:10.1002/palo.20012.

\section{Introduction}

[2] Hurricanes are natural heat engines, converting the potential energy stored in the surface ocean into wind. The efficiency of this engine is largely controlled by the oceanographic and atmospheric conditions in which the storm is forming and through which it translates. Instrumental observations suggest that the life cycle (genesis, intensity, and track) of a hurricane is influenced by a few key climate systems: the El Niño-Southern Oscillation (ENSO) [Gray, 1984], the West African Monsoon [Bell and Chelliah, 2006], solar variability [Cohen and Sweetser, 1975], sea surface temperatures [Emanuel, 2005; Webster et al., 2005],

\footnotetext{
${ }^{1}$ Department of Geology \& Geophysics, Woods Hole Oceanographic Institution, MS\#22, 360 Woods Hole Rd., Woods Hole, MA, 02543, USA. ${ }^{2}$ Department of Earth, Atmospheric, and Planetary Sciences, Massachusetts Institute of Technology, Cambridge, MA, 02139, USA.

Corresponding author: Michael R. Toomey, Department of Geology \& Geophysics, Woods Hole Oceanographic Institution, MS\#22, 360 Woods Hole Rd., Woods Hole, MA, 02543, USA. (mrt02008@mit.edu)

C2013. American Geophysical Union. All Rights Reserved. 0883-8305/13/10.1002/palo.20012
}

volcanic aerosols [Elsner and Kara, 1999], and the Atlantic multi-decadel oscillation [Goldenberg et al., 2001]. Yet, given the short length of reliable instrumental records ( $>1850$ A.D.), the extent to which these climatic forcings influence or even dominate hurricane behavior on geologic timescales remains poorly known.

[3] Many techniques have been developed to extend records of hurricane frequency using natural archives [Frappier et al., 2007; Hetzinger et al., 2008; Lawrence, 1998; Miller et al., 2006]. Some of the most successful proxies have made use of the capacity for storms to transport allochthonous sediment to coastal depositional basins [Donnelly and Woodruff, 2007; Donnelly et al., 2001; Lane et al., 2010; Liu and Fearn, 1993; Nott and Hayne, 2001; Park, 2012]. Barrier beach material overwashed into coastal lakes and marshes has proven a particularly effective proxy for developing continuous, multi-millennial records of hurricane activity because beach and nearshore material can be easily identified within pond or marsh sequences.

[4] Reconstruction of past hurricane frequency using overwash deposits documents substantial variability in tropical cyclone activity during the past 5500 yrs B.P. [Donnelly and Woodruff, 2007]. These studies have suggested a 
pervasive influence of ENSO and the West African Monsoon in pacing Atlantic hurricane frequency over the late Holocene. Mechanistically, El Niño is thought to cause increased vertical shear in the main development region limiting hurricane development [Gray, 1984]. Likewise, drought over the Sahel is associated with a weaker easterly wave, stronger vertical shear and, in turn, lower hurricane frequency [Goldenberg and Shapiro, 1996; Gray and Landsea, 1992].

[5] Modeling efforts indicate that long-term changes in solar insolation may also have played a key role in determining the Holocene hurricane activity. Korty et al. [2012] suggest that precession-forced increases in northern hemisphere summer insolation and atmospheric temperature around 6000 yrs B.P. may have limited hurricane potential intensity. However, the variable sensitivity of back-barrier sites to sea-level changes has hampered efforts to confidently develop mid-Holocene storm records and test this hypothesized forcing. Alternatively, sedimentation along carbonate bank margins has been shown to be relatively continuous over the past 7000 years [Grammer and Ginsburg, 1992; Roth and Reijmer, 2004; Wilber et al., 1990] and considerably less influenced by Holocene sea-level changes in comparison to coastal environments. As a result, these sediment records offer an unexplored archive of long-term tropical cyclone activity.

[6] Storms are thought to be important mechanisms for transporting carbonate bank sediments to the deep sea. Pilskaln et al. [1989] deployed sediment traps (500 mbsl) in the Providence Channel, the Bahamas, and found that fair-weather sedimentation was low in bank carbonates, the main component of the underlying sediments. To balance this discrepancy, they argue that storms are the key mechanism driving offbank transport. Elsewhere, sediment traps $(500,1500,3200 \mathrm{~m})$ deployed $75 \mathrm{~km}$ offshore of Bermuda captured this process during the passage of Hurricane Fabian in 2003 [Weber et al., 2006] and Ivan in 2010 (M. Conte, personal communication). At the Ocean Flux Program site, fallout of re-suspended platform material from these storms resulted in the largest observed sediment fluxes to date.

[7] Storms are likely even more important for mobilizing coarse bank-top sediments and moving them offbank. Working in the Northern Bahamas, Hine et al. [1981] found that under fair-weather conditions, tidal- and wind-generated currents were insufficient to mobilize sand and build observed sand waves. Even with gusts up to 20 knots, Grammer and Ginsburg [1992] did not observe transport of sand from the bank into the Tongue of the Ocean (Bahamas). Along the northern, open margin of St. Croix, the passage of Hurricane Hugo in 1989 removed 2 million kilograms of sand from the Salt River Submarine Canyon, the equivalent to a century of fair-weather conditions [Hubbard, 1992]. Together, these studies suggest that storms may periodically mobilize coarse bank-top sediments, deposit them offshore, and provide a long-term sedimentary record for hurricane activity.

[8] Unlike conventional back-barrier settings, sedimentary archives from carbonate bank margins likely extend into the early Holocene [Lynch-Stieglitz et al., 2009; Roth and Reijmer, 2004] and such sites are widespread in the tropics. These sites also offer the advantage of having high sedimentation rates (SR) while being accessible to large ocean-going research vessels capable of recovering such expanded sequences. While working on carbonate bank sediments also offers several obstacles (i.e. isolating the effects of local geomorphology, gravity flows, winnowing from currents, changes from fringing reefs to an open margin conditions on the banktop, deposition from tsunamis), these confounding effects can be overcome through careful site selection and thoughtful experimental design (see Methods section).

[9] Here, we use a suite of cores from the Leeward Great Bahama Bank to address three main questions: (1) Is it possible to reconstruct long-term hurricane records using cores from carbonate bank margins? (2) How has tropical cyclone activity around the Bahamas changed over the Holocene? (3) Does the record of hurricane strikes from the Bahamas support a relationship between ENSO, West African Monsoon or solar insolation, and storminess during the early Holocene?

\section{Study Site}

[10] Located in the Northeastern Caribbean, the Great Bahama Bank is optimally positioned to test this new approach for reconstructing past hurricane activity (Figure 1). Sedimentary records from the Bahamas and specifically at our site have been well studied, providing an established geologic context in which to test our proxy. Earlier work shows that offbank transport has led to rapid progradation of the leeward margin of the Great Bahama Bank during this and previous interglacial periods [Eberli et al., 1997]. Substantial areas along the modern platform margin (100-10 mbsl) were progressively flooded during deglaciation, initiating carbonate production before subsequent transport and deposition of this material offshore. The main phase of platform flooding was completed around 7000 yrs B.P. [Grammer and Ginsburg, 1992; Roth and Reijmer, 2004; Wilber et al., 1990], greatly enhancing the accumulation rates along the leeward margin.

[11] Previous work at our site documents a series of Holocene depositional environments moving from the banktop into the Straits of Florida [Rendle and Reijmer, 2002; Wilber et al., 1990]. We divide site geometry into five zones on the basis of slope and deposition rate (Figure 1c): (1) platform, (2) bank-edge depocenter: 10-100 mbsl, (3) upper slope: 100-250 mbsl, (4) mid-slope: 250-400 mbsl, and (5) lower slope: 400-700 mbsl. The platform itself ( $\sim 0$ to $10 \mathrm{mbsl}$ ) stretches $65 \mathrm{~km}$ west from the Andros Island (Figure $1 \mathrm{~b}$ ) before gradually transitioning to a shallowly oceanward dipping margin. Seismic surveys [Wilber et al., 1990] indicate that over the Holocene, up to $15 \mathrm{~m}$ of sediment has accumulated along the bank edge ( $3 \mathrm{~km}$ wide), gradually decreasing the slope since flooding. The shelf break ( $\sim 100 \mathrm{mbsl})$ marks a shift to steeper slopes $(0.1$ to $0.15)$ and an area of low deposition. Sedimentation rates increase substantially on the upper slope $(>250 \mathrm{mbsl})$ with a large Holocene accretionary wedge, upwards of $50 \mathrm{~m}$ thick [Wilber et al., 1990] grading into the Straits of Florida [Ryan et al., 2009]. Morphologically, the lower slope ( 400-700 mbsl) is characterized by a network of wide, shallow gullies that distribute material moving offbank [Mulder et al., 2012]. However, comparison of ridge and gully deposition using cores taken from the Northwest Providence Channel, Bahamas, indicates that there is little difference in ongoing sedimentation between sites and that channel features may be relict from earlier glacial cycles [Burns and Neumann, 1987]. Earlier work [Lund and Curry, 2006, Lynch-Stieglitz et al., 2009; Lund et al., 2006; Lynch-Stieglitz et al., 2011] 
TOOMEY ET AL.: A 7000 YR RECORD OF HURRICANE ACTIVITY

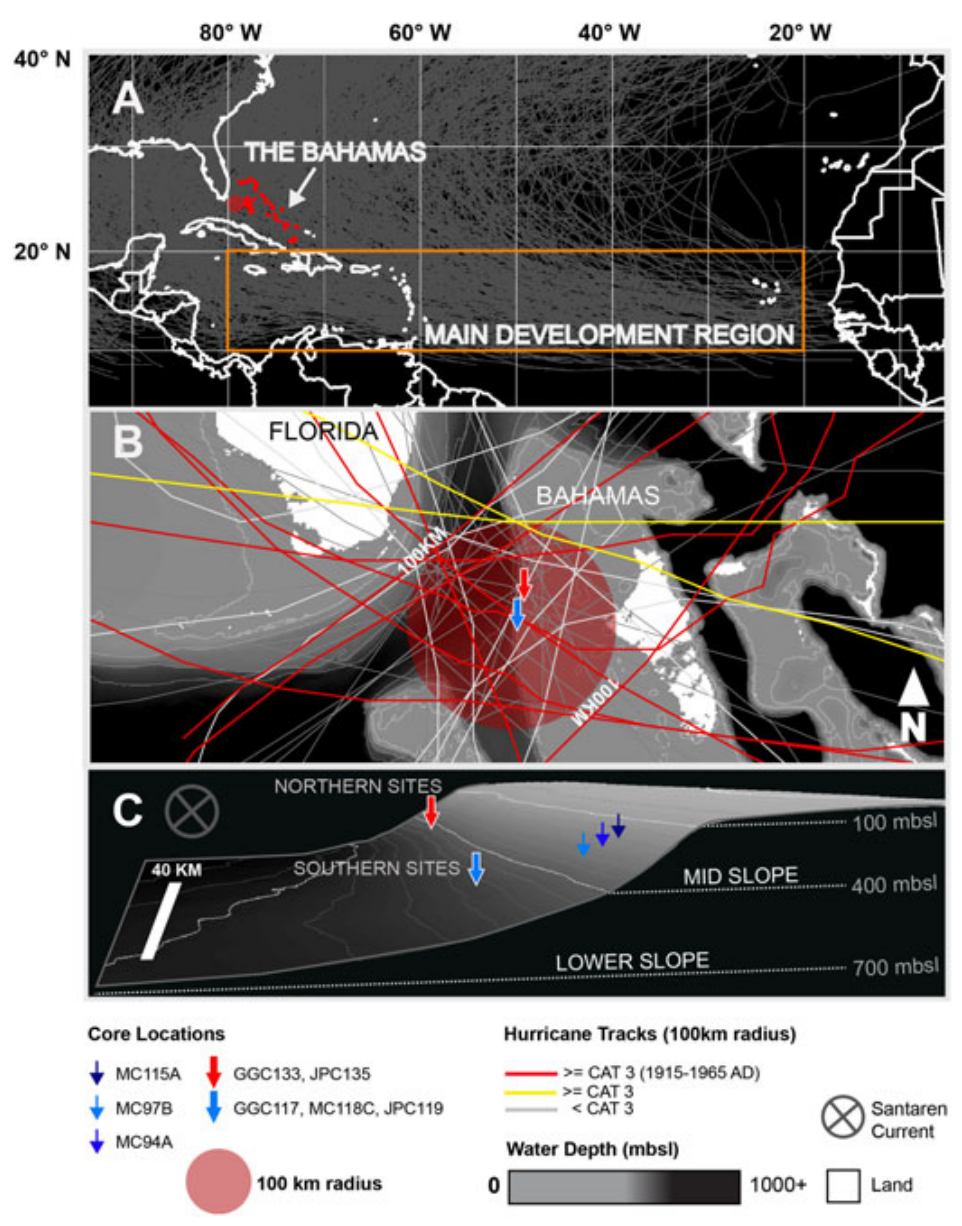

Figure 1. (a) Map showing North Atlantic Hurricanes since 1851 A.D. Blue circle shows the location of cores used in this study. Grey lines show the track of storms from the IBTRaCS dataset [Knapp et al. 2010]. The main development region is outlined in orange. (b) Bathymetric map of the western Great Bahama Bank and storm tracks passing near our site. Tracks of major hurricanes passing within 100 $\mathrm{km}$ of our site between 1915 and 1965 are shown by red lines. The two major hurricanes that passed near our site that did not occur during this interval (1888 and 1992 A.D.) are shown by yellow lines. Minor hurricanes/storms passing within that radius are highlighted in light grey lines. (c) 3D image showing general bank morphology at our site.

on the cores used in this study documented more than $12 \mathrm{~m}$ of Holocene sediment with relatively constant sedimentation rates since 7000 yrs B.P. at our site.

[12] Instrumental observations (IBTRaCS; http://www. ncdc.noaa.gov/oa/ibtracs/) show that the Bahamas lie along a major storm track and that our site has been hit many times since 1851 A.D. [Knapp et al. 2010]. Over this interval, 45 storms ( $\geq$ tropical depression) have passed nearby $(<100 \mathrm{~km})$ our sites (Figure 1). Twelve of these storms were at major hurricane strength ( $\geq$ CAT 3, 86 knots 10 min sustained winds) within a $100 \mathrm{~km}$ radius of our core locations. The pattern of hurricane strikes near the Great Bahama Bank appears consistent with peaks in basin-wide storm frequency seen between 1920 and 1970 AD. A substantial increase in intense storms near our site in the Bahamas occurs between 1915 and 1965 A.D. with 10 of 12 major hurricanes occurring over this interval. The two storms (>CAT 3) not occurring over this interval (1888 and 1992 A.D.) also track somewhat further North than the other major hurricanes passing near our site during the historic interval. Together with several nearby overwash reconstructions [Donnelly and Woodruff, 2007; Park, 2012; van Hengstum et al., 2013] these known hurricane strikes provide an opportunity to calibrate our storm record.

\section{Materials and Methods}

[13] The methods for this study were intended to accomplish two objectives: (1) to use a depth transect (Table 1) of multi-cores across the slope (KNR 166-2 MC 115A: 202 mbsl, MC 94A: 259 mbsl, MC 97B: 303 mbsl, MC 118C: $531 \mathrm{mbsl}$ ) to establish sedimentation patterns during fair-weather versus storms, and control for changes in the 
TOOMEY ET AL.: A 7000 YR RECORD OF HURRICANE ACTIVITY

Table 1. Core Locations and Water Depths ${ }^{\mathrm{a}}$

\begin{tabular}{|c|c|c|c|c|}
\hline Sites & Latitude $\left({ }^{\circ} \mathbf{N}\right)$ & Longitude $\left({ }^{\circ} \mathbf{W}\right)$ & Water Depth (m) & Modeled Timespan \\
\hline \multicolumn{5}{|l|}{ Northern Sites } \\
\hline KNR166-2 GGC 133 & 24.8360 & 79.2185 & 445 & 0 to $1500 \mathrm{yrs} \mathrm{BP}$ \\
\hline KNR166-2 JPC 135 & 24.8358 & 79.2187 & 446 & 200 to $9500 \mathrm{yrs} \mathrm{BP}$ \\
\hline \multicolumn{5}{|l|}{ Southern Sites } \\
\hline KNR166-2 MC 94A & 24.5687 & 79.2255 & 259 & -50 to $280 \mathrm{yrs} \mathrm{BP}$ \\
\hline KNR166-2 MC 97B & 24.5640 & 79.2295 & 303 & -50 to 165 yrs BP \\
\hline KNR166-2 MC 115A & 24.5712 & 79.2213 & 202 & -50 to $140 \mathrm{yrs} \mathrm{BP}$ \\
\hline KNR166-2 GGC 117 & 24.5907 & 79.2687 & 528 & 330 to $2400 \mathrm{yrs} \mathrm{BP}$ \\
\hline KNR166-2 MC 118C & 24.5906 & 79.2687 & 531 & -50 to 750 yrs BP \\
\hline KNR166-2 JPC 119 & 24.5905 & 79.2687 & 529 & 200 to $10250 \mathrm{yrs} \mathrm{BP}$ \\
\hline
\end{tabular}

geomorphological environments encountered moving offbank, and (2) to use a $40 \mathrm{~km}$, along-bank transect of gravity and jumbo piston cores (JPC 119: 529 mbsl, JPC 135: $446 \mathrm{mbsl}$ ) to establish a coherent pattern of storm-related sedimentation since the early Holocene and isolate the effects from local gravity flows.

[14] Each of the multi-cores was continuously sampled at $0.5 \mathrm{~cm}$ resolution and wet sieved at $63 \mu \mathrm{m}$. At the same time, a sample was taken every $0.25 \mathrm{~cm}$ for analysis using a Beckman-Coulter laser particle size analyzer. Based on this analysis, we calculated the standard deviation of the grain size distribution (sorting) and used it to assess the impact of winnowing from the Florida/Santaren Currents. Similar laser particle size (LPS) methods were used for the piston and gravity cores but with sampling resolutions of 1 and $0.5 \mathrm{~cm}$, respectively. Comparison of these records to nearby overwash reconstructions at sites with various orientations to the sea was used to rule out tsunamis as a main driver of offbank transport. The coarse sediment retained after the bulk samples were sieved at $63 \mu \mathrm{m}$ was also qualitatively inspected under a stereo microscope to explore downcore changes in faunal assemblages and control for shifts in sediment composition on the bank-top. We used an ITRAX core scanning XRF to radiograph each of the multicores and identify potential sedimentary structures.

[15] The cores were chronologically constrained with both ${ }^{210} \mathrm{~Pb}$ and radiocarbon dating. ${ }^{210} \mathrm{~Pb}$ dating was used to establish a high-resolution chronology in the coretop so our record could be compared to storm histories for the Bahamas. After the bulk sediment was sampled from the core, dried, and homogenized using a mortar and pestle, ${ }^{210} \mathrm{~Pb}$ activity was measured using gamma spectroscopy [e.g., Gäggeler et al., 1976]. In general, we interpreted a ${ }^{210} \mathrm{~Pb}$ profile (Figure 2a, black line) based on the observed activity (Figure 2a, red dots) and used a constant initial concentration model (CIC) to extract a sedimentation rate over the past 150 years [Appleby and Oldfield, 1978; Appleby and Oldfieldz, 1983]. Radiocarbon dating of mixed planktonic foraminifera (Table 2) was used to supplement the previously established chronologies for these cores [Lund and Curry, 2006; Lund et al., 2006; Lynch-Stieglitz et al., 2009; Lynch-Stieglitz et al., 2011]. Analysis was performed at the National Ocean Sciences Accelerator Mass Spectrometry facility in Woods Hole, Massachusetts. Dates were calibrated using CALIB 6.0 and a standard marine reservoir correction of 400 years. Linear interpolation was used to set the chronology between time points.
[16] Spectral amplitudes and significance were calculated using REDFIT [Schulz and Mudelsee, 2002]. Unlike conventional spectral techniques, REDFIT directly computes spectral amplitudes using the Lomb-Scargle Fourier transform [Lomb, 1976; Scargle, 1982], therefore avoiding errors introduced through interpolation of uniform time spacing. Significant peaks were evaluated against a red noise background and bias corrected using 2000 Monte-Carlo simulations.

\section{Results and Discussion}

\subsection{Multicore ${ }^{210} \mathrm{~Pb}$ Chronologies and Grain-size}

[17] A matrix of fine-grained carbonate mud (median grainsize $\sim 20 \mu \mathrm{m}$ ) and aragonite needles was the primary sedimentary constituent in the cores, which in turn provides matrix support to coarse-grained biogenic grains (e.g., benthic and planktic foraminifera, halimeda, and shell fragments) and few carbonate clasts. These sediments typify deposition on the slope of the Bahamian carbonate banks during Neogene sea-level highstands [Bernet et al., 2000]. In general, finegrained carbonate mud with some coarse biogenic material represents background sedimentation, whereas the proportion of coarse-grained biogenic material increases during transport events [Bernet et al., 2000].

[18] On a more detailed level, neither visual inspection nor $\mathrm{x}$-radiography could reveal any sedimentary structures in the cores. Further detailed analysis of the textural changes, however, revealed synchronous variation in the quantity of coarse material (percent sand in $\mu \mathrm{m}$ ) deposited at the core sites (Figure 2). This coarse material is primarily biogenic and dominated by both benthic and planktic foraminifera. Benthic foraminifera included shallow platform-derived species such as miliolids (e.g., Quinqueloculina, Triloculina) and taxa employing photosymbionts (e.g., Amphistegina, Arachaias), as well as rotaliids. Foraminifera also dominate the coarse-grained sediments deposited by turbidites along the western margin of the Great Bahama Bank during the Neogene; however, these carbonate turbidites generally exceeded $25 \mathrm{~cm}$ in thickness [Bernet et al., 2000]. In contrast, we observed discrete variability and peaks in coarse-grained sedimentation at centimeter scale. These results indicate that the recovered sequences most likely contain an alternation between background fine-grained sedimentation versus event layers containing relatively more coarse-grained material derived from the bank top or biogenic sediment concentrated during offshore transport. 
(A) ${ }^{210} \mathrm{~Pb}$

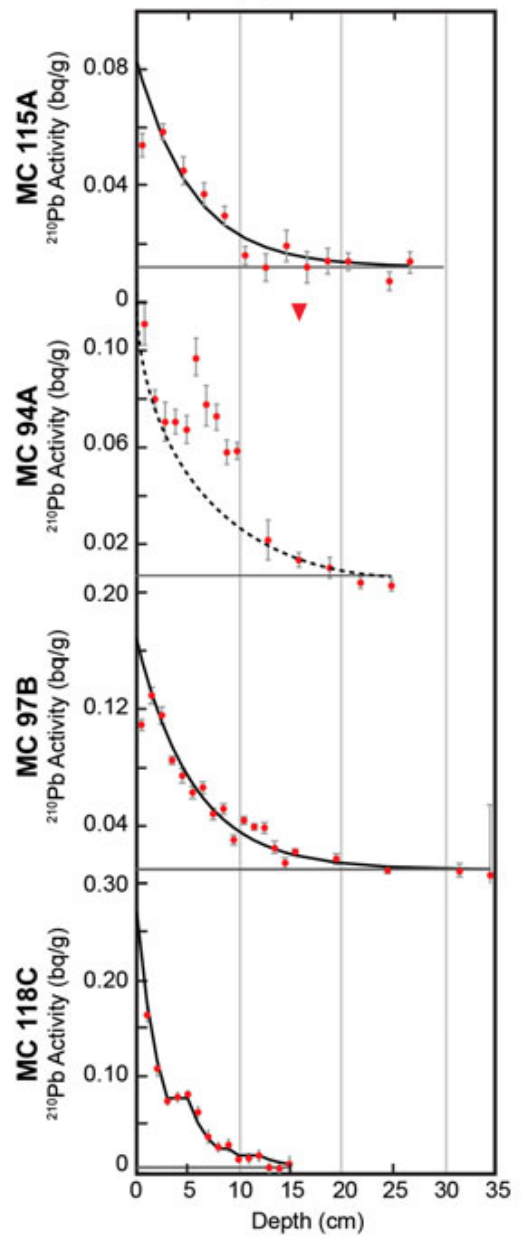

$\begin{array}{ll}{ }^{210} \mathrm{~Pb} \text { Activity } & - \text { Supported }{ }^{210} \mathrm{~Pb} \\ \sim 1850 \mathrm{AD} & -{ }^{210} \mathrm{~Pb} \text { Model }\end{array}$
(B) Grain Size

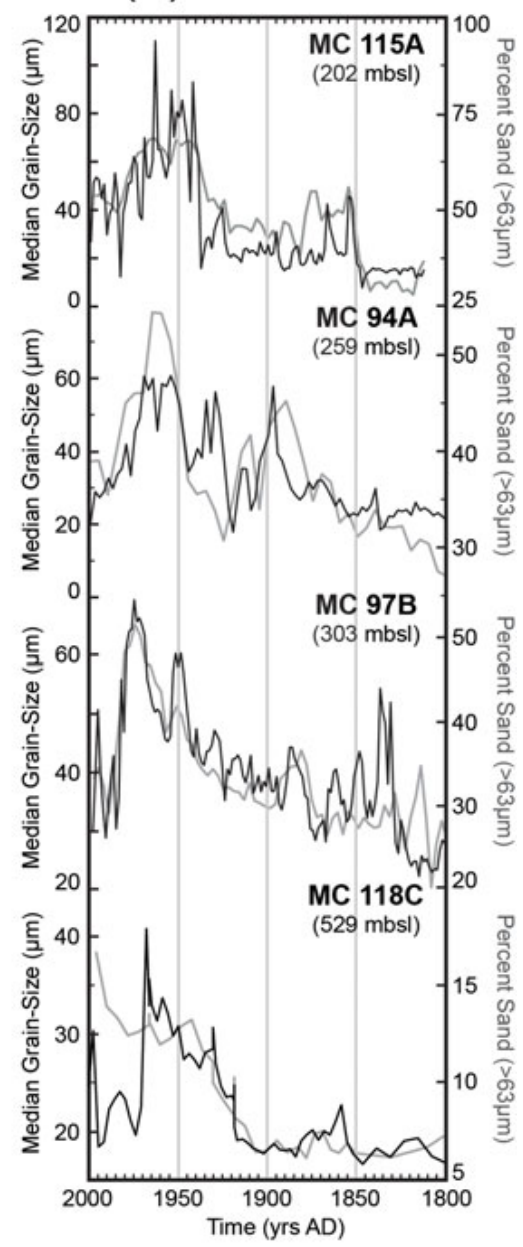

- Median Grain-Size

- Percent Sand

Figure 2. (a) ${ }^{210} \mathrm{~Pb}$ profiles and age models for same multi-core transect. Measured ${ }^{210} \mathrm{~Pb}$ activity is given by red circles. Supported ${ }^{210} \mathrm{~Pb}$ is shown as light grey line. Inferred ${ }^{210} \mathrm{~Pb}$ model is shown in black curves. For MC 94A, a black dashed line is used to show that the ${ }^{210} \mathrm{~Pb}$ chronology is likely made more complex by erosion and re-deposition. Approximate depth of 1850 A.D. in MC $94 \mathrm{~A}$ determined by ${ }^{210} \mathrm{~Pb}$ is marked by red triangle. (b) d50 grain-size (black line) and percent sand ( $>63 \mu \mathrm{m}$; grey line) are shown for our offbank series of multicores (top: KNR 166-2 MC 115A; MC 94A; MC 97B; bottom: MC 118C).

[19] On the broad scale, ${ }^{210} \mathrm{~Pb}$ activity declines almost exponentially downcore at each of our multi-core sites, largely conforming to the expectations of our CIC model with steady accumulation rates (Figure 2). However, coretop ${ }^{210} \mathrm{~Pb}$ activity does increase with increasing offshore distance from the Great Bahama Bank $(\mathrm{MC} 115 \mathrm{~A}=0.08 \mathrm{bq} / \mathrm{g}$; $\mathrm{MC} 118 \mathrm{C}=0.25 \mathrm{bq} / \mathrm{g}$ ), possibly indicating that certain banktop constituents or grain-size fractions contain slightly different initial concentrations ${ }^{210} \mathrm{~Pb}$.

[20] ${ }^{210} \mathrm{~Pb}$ profiles along our depth transect reflect different sedimentation rates across the slope (Figure 2) and fall within three depositional zones (Figure 1c): variable deposition and erosion (upper slope); continuous deposition (mid-slope) and event deposition (lower slope) with gradual background sedimentation. SR at sites on the upper slope $(\mathrm{MC} 115 \mathrm{~A} \mathrm{SR}=1.6 \mathrm{~mm} / \mathrm{yr} ; 94 \mathrm{~A} \mathrm{SR}=1.0 \mathrm{~mm} / \mathrm{yr})$ appear more variable, with higher accumulation rates coinciding with deposition of coarse material. This suggests that deposition may be driven by hurricane events, and that under fair weather conditions, most material bypasses the upper slope. The divergence of MC 94A's ${ }^{210} \mathrm{~Pb}$ profile from the expected curve may indicate that a more complicated mix of deposition and erosion is occurring on the upper slope. Higher accumulation rates and continuous deposition occurs 
TOOMEY ET AL.: A 7000 YR RECORD OF HURRICANE ACTIVITY

Table 2. Radiocarbon Dates for Cores Used in This Study ${ }^{\mathrm{a}}$

\begin{tabular}{|c|c|c|c|c|c|}
\hline Site & Depth $(\mathbf{c m})$ & Species & ${ }^{14}$ C Age (yrs BP) & ${ }^{14}$ C Error (years) & Cal Age (yrs BP) \\
\hline \multirow[t]{5}{*}{ KNR166-2 GGC 117} & 31.0 & G. ruber & 1090 & 30 & 649 \\
\hline & 61.0 & G. ruber & 1430 & 30 & 962 \\
\hline & 89.0 & G. ruber & 1550 & 30 & 1101 \\
\hline & 148.5 & G. ruber & 2330 & 90 & 1954 \\
\hline & 205.0 & G. ruber & 2570 & 100 & 2224 \\
\hline \multirow[t]{3}{*}{ KNR166-2 MCA 118} & 0.5 & G. ruber & $>\operatorname{Mod}$ & & \\
\hline & 13.0 & G. ruber & 635 & 25 & 281.5 \\
\hline & 36.5 & G. ruber & 1320 & 45 & 885 \\
\hline \multirow[t]{9}{*}{ KNR166-2 JPC 119} & 10.5 & G. sacculifer & 575 & 40 & 206 \\
\hline & 190.5 & Mixed planktonics & 2190 & 25 & 1788 \\
\hline & 440.5 & Mixed planktonics & 2840 & 30 & 2610 \\
\hline & 770.5 & Mixed planktonics & 3870 & 25 & 3838 \\
\hline & 1070.5 & G. sacculifer & 4960 & 35 & 5306 \\
\hline & 1130.5 & G. sacculifer & 5270 & 50 & 5632 \\
\hline & 1200.5 & G. sacculifer & 6190 & 60 & 6630 \\
\hline & 1300.5 & G. sacculifer & 8710 & 55 & 9387 \\
\hline & 1310.3 & G. sacculifer & 9420 & 50 & 10268 \\
\hline \multirow[t]{3}{*}{ KNR166-2 GGC 133} & 0.5 & G. ruber & $>$ Mod & & \\
\hline & 136.0 & G. ruber & 1570 & 35 & 1122 \\
\hline & 267.5 & G. ruber & 1920 & 30 & 1454 \\
\hline \multirow[t]{9}{*}{ KNR166-2 JPC 135} & 10.5 & G. sacculifer & 580 & 35 & 215 \\
\hline & 200.5 & Mixed planktonics & 2050 & 35 & 1620 \\
\hline & 510.5 & Mixed planktonics & 2710 & 30 & 2392 \\
\hline & 720.5 & G. sacculifer & 3430 & 50 & 3307 \\
\hline & 1080.5 & Mixed planktonics & 5450 & 45 & 5822 \\
\hline & 1290.5 & G. sacculifer & 6800 & 65 & 7326 \\
\hline & 1308.3 & Mixed planktonics & 7790 & 50 & 8260 \\
\hline & 1322.3 & G. sacculifer & 7560 & 40 & 8016 \\
\hline & 1328.5 & G. sacculifer & 8820 & 45 & 9484 \\
\hline
\end{tabular}

${ }^{a}$ Radiocarbon chronology for MC $118 \mathrm{C}$ is based on dates in corresponding multi-core MC $118 \mathrm{~A}$.

on the mid-slope (MC 97b; $303 \mathrm{mbsl}$; SR $=1.7 \mathrm{~mm} / \mathrm{yr}$ ). At the toe of the slope (MC 118C; $531 \mathrm{mbsl}, \mathrm{SR}=0.5 \mathrm{~mm} / \mathrm{yr}$ ), the ${ }^{210} \mathrm{~Pb}$ chronology indicates periodic deposition of event layers (1-2 cm thick) and gradual, but steady background sedimentation. The largest grain size event (3-5 cm depth) appears to have internal bedding, while the two earlier events $(8-9$ and10-12 cm) fine upwards. Together, the ${ }^{210} \mathrm{~Pb}$ chronologies indicate that small turbidites are the likely mechanism for moving sediments offbank, and that the most continuous sedimentary records occur below the mid-slope (400 mbsl).

[21] Despite the complex sedimentary mechanics across the bathymetric and geographic transects in the framework of our ${ }^{210} \mathrm{~Pb}$ chronologies, a coherent pattern of coarse layers emerges between the multi-cores and both grain-size techniques (i.e., sieving or LPS). Grain-size patterns in our multicore transect (200-530 mbsl) are similar and do not appear greatly affected by changes in geomorphology moving downslope, in particular channelization below $400 \mathrm{mbsl}$ [Mulder et al., 2012]. Together, they show a substantial rise in coarse-grained deposition after 1915 A.D. from several discrete events (Figure 3). The coarsest peaks match well with a documented period of increased major storm frequency (10 CAT 3+ hurricanes) near the Bahamas between 1915 and 1965 A.D. The three thickest coarse layers (3-5, $8-9$, and $10-12 \mathrm{~cm}$ ) in our records occur around 1920, 1930. and 1965 A.D., possibly reflecting deposition during Hurricane Betsy (1965 A.D., CAT 3) and two unnamed category 4 storms which hit the Bahamas in 1919 and 1929 A.D. However, given historic return intervals ( $\sim 3$ years) and sedimentation rates at our sites $(0.5-1.7 \mathrm{~mm} / \mathrm{yr})$, most peaks likely reflect increased hurricane activity on decadal

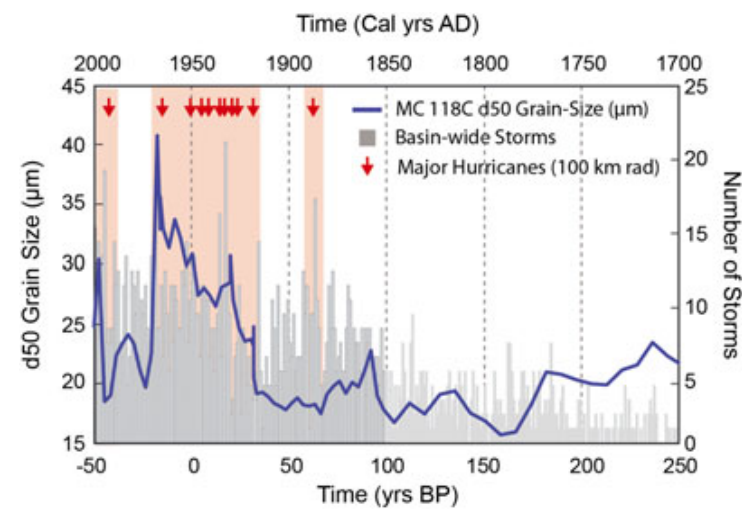

Figure 3. Comparison of historic storms and bulk grain-size records. A comprehensive record of Historic North Atlantic hurricanes was compiled from HURDAT (2000-1851 A.D.), Chenoweth [2006], and Scheitlin et al., [2010] (shaded grey; $1850-1700$ A.D.). Annual number of Atlantic storms ( $\geq$ tropical storm) is shown by grey bars. Major hurricanes passing within $100 \mathrm{~km}$ of our site are highlighted by red arrows. d50 grain-size from core KNR $166-2 \mathrm{MC} 118 \mathrm{C}$ is given by the blue line.

timescales rather than individual storms. Two periods of very low coarse grain deposition occur from 1875 to 1915 A.D. and 1965 to 1990 A.D., and are consistent with observed decreases in major hurricane frequency in historic records for the Bahamas. The lower frequency of documented storms 
recorded prior to 1850 A.D. may reflect that fewer ships were crossing the Atlantic at this time and many storms not making landfall were missed.

[22] Overall, this pattern suggests a close link between major storms and coarse sediment deposition; however, the exact size of individual layers is likely impacted by several factors: (1) storm intensity, (2) approach, and (3) speed, as well as (4) sediment availability on the banktop. Storm intensity and wind speed are likely closely tied to wave processes, shear stress at the bed, and therefore the ability of a storm to mobilize and transport coarse sediment [Chang et al., 2001]. In general, more intense storms with stronger winds are likely able to transport coarser sediment. Storm approach is also likely to play a key role in determining if sediment, once mobilized, is moved offbank. In general, major storms have tracked east-west across the Bahamas (Figure 1). Because of the cyclonic orientation of storm winds, hurricanes tracking north of our site will build up water on the platform. Upon release, this water will flow offbank, eroding sediment along the platform edge [Hubbard, 1992]. Alternatively, storms passing to the south of our site have their strongest winds oriented offbank. A direct strike may result in little offbank transport as the peak winds will be oriented along bank (north-south). In addition, the speed of the storm will limit the time hurricane winds have to deliver material offbank. Slower moving storms may clear most of the fine sediment offbank early on, leaving only coarse sediment to be mobilized and redeposited offbank later in the event. Likewise, passage of many large storms over a relatively short interval may deplete banktop fines, leading to progressively coarser deposits. Deployment of sediment traps to capture this process is necessary to better constrain each of these influences.

[23] On the basis of our analysis and in light of previous efforts, we do not believe that these deposits were formed either by the passage of winter storm fronts or winnowing. Density cascading during the passage of winter storms has been shown to be significant in transporting fine mud off platform [Wilson and Roberts, 1995], but these flows are likely low in coarse silt and sand [Neumann and Land, 1975]. Coarse deposits are also not readily explained as derived from winnowing by the Florida current because, as noted above, ${ }^{210} \mathrm{~Pb}$ chronologies indicate that much of the coarse sediment on the lower slope is from "instantaneous" event deposits. Moreover, coarse layers in our multi-cores do not show significantly increased sorting as would be expected from winnowing. In fact, a Pearson's productmoment test (MATLAB: corr) indicates only a weak, negative correlation $(r=-0.22, p<0.01)$ between grain size and sorting (standard deviation) for MC118C.

[24] Synthesis of ${ }^{210} \mathrm{~Pb}$ chronologies, downslope grainsize records, and historic storm records, introduces confidence for using coarse grain deposition as a proxy for major storms or intervals of major storm activity at the study site. Our records support the hypothesis that storms cause coarse material from the bank edge to become re-suspended and carried offbank as turbidity currents. Deposition of several large $(1-2 \mathrm{~cm}$ thick) discrete coarse-grained layers during major hurricane events during the historic interval ( $>1850$ A.D.) indicates that the lower slope presents a good depositional setting for developing longer hurricane records.

\subsection{Comparison of Event Deposition to Previous Late- Holocene Overwash Records}

[25] Two pairs of gravity and piston cores (JPC 119: 529 mbsl, JPC 135: $446 \mathrm{mbsl}$ ) stretching $40 \mathrm{~km}$ along bank define a consistent pattern of high-energy event deposition (Figure 4) and define at least four periods of increased coarse fraction deposition: (1) 4600 to 3800 yrs BP; (2) 2400 to $1800 \mathrm{yrs} \mathrm{BP}$; (3) 1200 to $500 \mathrm{yrs} \mathrm{BP}$ and (4) 50 yrs BP to present. Given that these sites are separated by more than 40 $\mathrm{km}$ and that the event layers are synchronous across this transect indicates these deposits are not explained by random and localized debris flow events. Furthermore, it is improbable that mass wasting would occur, given that the maximum gradient $(0.15)$ in the upper slope is below the angle of repose for mixed coarse-fine grained sediment [Kenter, 1990]. The simplest explanation for these geographically distributed and synchronous coarse, high-energy layers is storm-mediated transport.

[26] Similar increases in hurricane activity are widely documented throughout the North Atlantic between 4900 and 3600, 2500 and 1000, and 600 and $400 \mathrm{yrs} \mathrm{BP}$, and since 1700 A.D. [Donnelly and Woodruff, 2007; Liu and Fearn, 1993; Park, 2012; Scileppi and Donnelly, 2007; van Hengstum et al., 2013], consistent with our offshore results, and have previously been attributed to changes in El Niño and the West African Monsoon. These changes are observed throughout the North Atlantic in coastal locales with various geometric orientations to the ocean, which means they cannot be sufficiently explained by tsunami events. Correspondence between our records and previous Caribbean overwash records gives further confidence in interpreting older, mid-Holocene, coarse deposits in our cores as hurricane-derived.

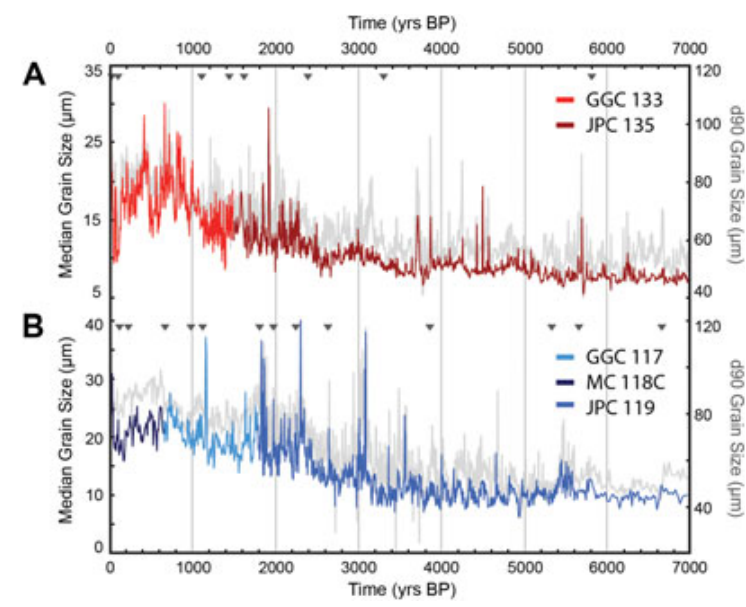

Figure 4. Storm-related changes in grain size along the Great Bahama Bank. Median (d50) grain size shown in red (northern sites) or blue (southern sites). d90 grain size shown by grey line. Grey triangles mark radiocarbon tie points. (a) Light red shows d50 grain size from KNR166-2 GGC 133, while dark red line gives the median grain-size profile for KNR 166-2 JPC 135. (b) Compiled profiles at our southern site using KNR 166-2 MC118C (dark blue), GGC117 (light blue), and JPC119 (medium blue). Modeled timespans for each core are given in Table 1. 


\subsection{Mid-Late Holocene Hurricane Activity}

[27] These short-term peaks in storminess, likely forced by ENSO and the West African Monsoon, overlie a much broader increase in the background storm climate between 3000 to $2000 \mathrm{yrs}$ BP. Prior to $4400 \mathrm{yr}$ BP, storms appear infrequent and active intervals are short-lived (e.g., 5800 to 5500 yrs BP). Given our site geometry, this long term increase in coarse sedimentation is unlikely related to changing sea level or sensitivity to storms. In fact, lower sea level during the mid-Holocene would be expected to have an opposite effect, making it easier for storms to mobilize sediment from a shallower banktop and move it offshore. Relatively uniform sedimentation rates between $\sim 6000$ and $2000 \mathrm{yrs}$ BP in our piston cores (JPC $119 \mathrm{SR}=2.4 \mathrm{~mm} / \mathrm{yr}$, JPC $135 \mathrm{SR}=2 \mathrm{~mm} / \mathrm{yr}$ ) further indicate that Holocene sea-level rise did not alter the region's sensitivity to hurricane activity. On the other hand, decreasing sedimentation rates $(\mathrm{GGC} 117 \mathrm{SR}=1.1, \mathrm{GGC} 133 \mathrm{SR}=2 \mathrm{~mm} / \mathrm{yr})$ since $\sim 2000$ yrs BP may in fact reflect increased storm frequency with hurricanes sweeping much of the fine sediment into the Straits of Florida.

\subsection{Connections Between Hurricanes and Other Climate Systems}

[28] Our results suggest a dynamic relationship between hurricanes and climate with different forcings playing a driving role during different parts of the Holocene (Figure 5). Major changes in storm frequency during the late Holocene appear driven mostly by an ENSO-like forcing and West African Monsoon variability, consistent with previous results [Donnelly and Woodruff, 2007]. However, these relationships appear to breakdown during the mid-Holocene when we observe lower hurricane activity despite a stronger West African Monsoon [Nguetsop et al., 2004] and weaker El Niños [Makou et al., 2010; Moy et al., 2002], factors thought to enhance hurricane activity.

[29] The diminished role of El Niño in forcing North Atlantic hurricane activity during the mid-Holocene may have resulted from decreased high-frequency ENSO variability at this time [Korty et al., 2012; Moy et al., 2002]. Korty et al. [2012] suggest that the rapid shifts in atmospheric temperature experienced during ENSO events may drive large fluctuations in the ocean-atmosphere thermal gradient and therefore hurricane activity. A recent reconstruction by Makou et al. [2010] suggests that the magnitude of ENSO variability was substantially lower prior to 2000 yrs BP, possibly explaining the decreased mid-Holocene hurricane activity we observe in our records. Still, many current proxies used to reconstruct Holocene-scale records of ENSO do not satisfactorily reproduce observational data. More explicit, annually resolved records are needed to definitively characterize the relationship between tropical Pacific dynamics and Atlantic hurricane activity.

[30] Likewise, key differences in the behavior of the West African Monsoon and the ITCZ during the mid-Holocene may have augmented their roles in shaping North Atlantic storm activity. At present, the ITCZ's summer position promotes monsoon and hurricane development near the Sahel region of Africa (Figure 1). However, evidence of ITCZ migration from the Cariaco Basin [Haug et al., 2001] indicates that its mean position may have been

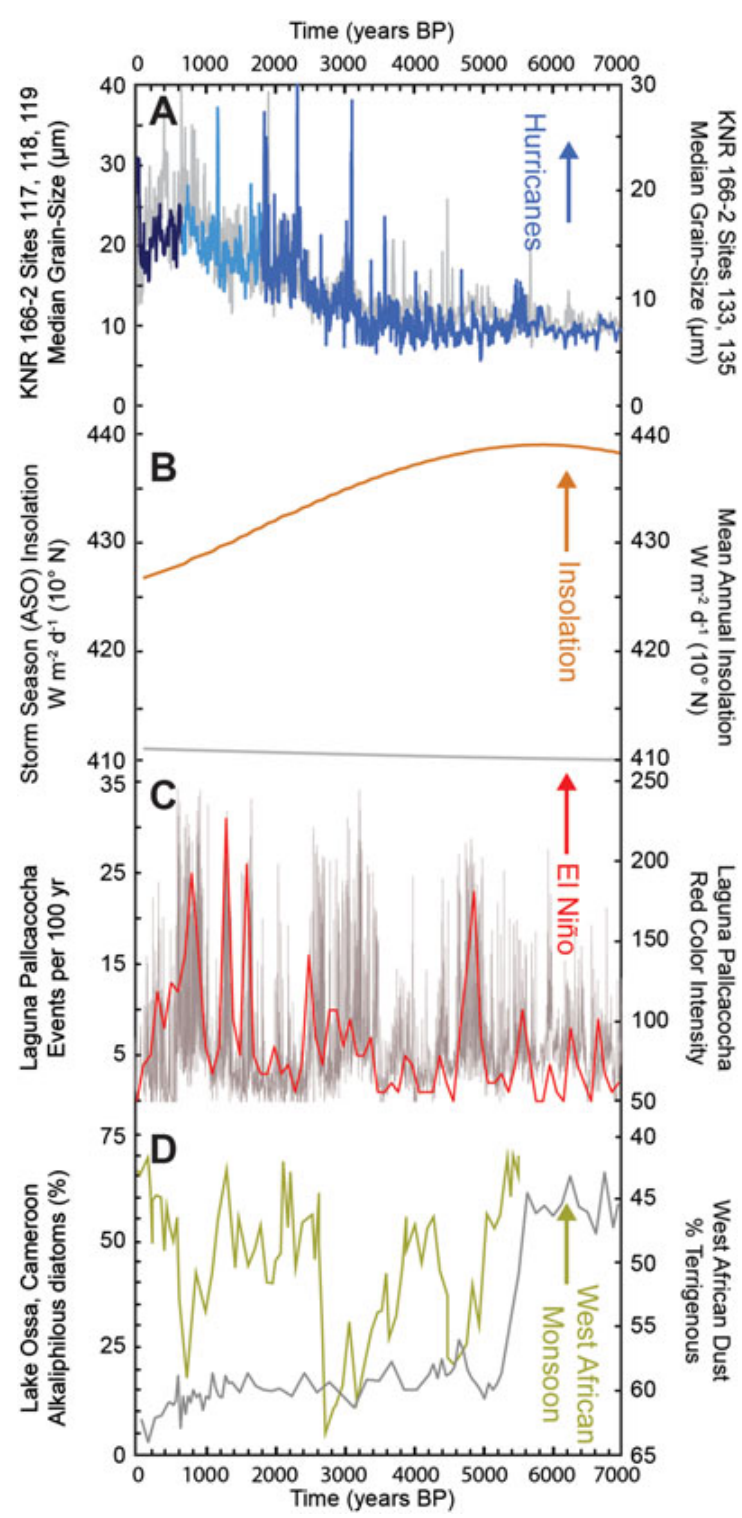

Figure 5. Comparison of the Bahamas hurricane reconstruction to records of ENSO, solar insolation, and the West African Monsoon. (a) Bahamas hurricane records from our southern sites (KNR 166-2 MC118C, GGC117, and JPC119) are shown in blue (same as Figure 4). Grain-size profiles for our northern sites (KNR 166-2 GGC133 and JPC135) are shown in grey. (b) Storm season (ASO) incoming solar insolation at $10^{\circ} \mathrm{N}$ (orange) and mean annual insolation at $10^{\circ} \mathrm{N}$ (grey) [Huybers, 2012 (inso.m, http://www.people.fas.harvard.edu/ phuybers/ Mfiles/Toolbox/), and references therein]. (c) Laguna Pallcochoa red color intensity (grey), El Niño events per 100 years (red) [Moy et al., 2002]. (d) Lake Ossa Alkaliphilous diatoms (\%) (yellow) [Nguetsop et al., 2004]. Terrigenous dust flux at site $658 \mathrm{C}$ offshore of West Africa (grey) [deMenocal et al., 2000]. 
considerably further north during the mid-Holocene, reflecting warmer NH summers. This shift coincides with the African Humid Period and inferred increases in precipitation over North Africa [deMenocal et al., 2000] (Figure 5). A northward shift in hurricane genesis locations (and tracks) may have considerably diminished storm frequency in the Bahamas and possibly the ability to generate major hurricanes in the North Atlantic.

[31] Recent modeling efforts implicate increased solar radiation as a limitation to hurricane potential intensity across much of the North Atlantic during the mid-Holocene [Korty et al., 2012]. Increased insolation and atmospheric temperature may work to decrease the thermal gradient between the ocean and tropopause, effectively limiting potential intensity. This effect appears particularly strong between 20 and $35^{\circ} \mathrm{N}$ in the North Atlantic. Even today, conditions are less conducive to developing major storms at these latitudes than further south [Korty et al., 2012]. Together, this suggests that increased $\mathrm{NH}$ summer insolation combined with a northward shift in the ITCZ and main genesis location may have resulted in the observed decrease in hurricane activity around the Bahamas during the mid-Holocene.

[32] Our results also indicate that significant changes in hurricane frequency occur on much shorter timescales as well. Spectral analysis of our grain-size records reveals many significant $(90 \%)$ peaks for periods between 11 and 20 years (Figure 6). Those peaks between 11 and 14 years

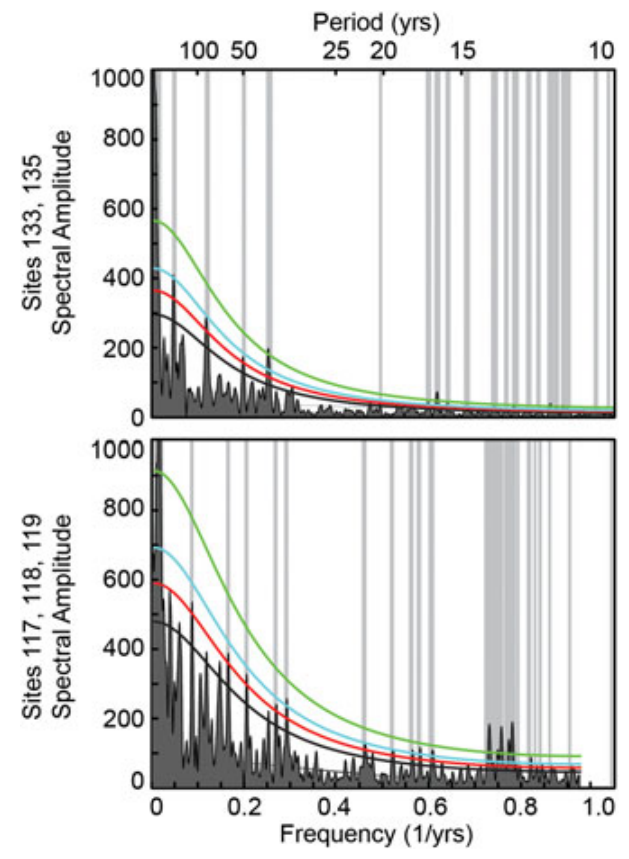

Figure 6. Spectral amplitudes for median grain-size records (d50) calculated using REDFIT [Schulz and Mudelsee, 2002]. Parameters are as follows: $\mathrm{OFAC}=4, \mathrm{HIFAC}=1, \mathrm{n} 50=4$, Iwin $=1$. Northern sites (top). Southern sites (bottom). Spectral amplitudes shown in grey. $\chi^{2}$ significance levels are shown as black (80\%), red (90\%), blue (95\%), and green (99\%). Grey bars highlight peaks exceeding a $90 \% \chi^{2}$ threshold. are particularly strong. One relatively unexplored mechanism for this variability is short-term change in solar insolation. High frequency oscillations in solar radiation at 11 year periods (Schwabe cycle) are well documented in observational records [Lockwood and Fröhlich, 2007 and references therein]. Although changes in top of the atmosphere irradiance are relatively minor $(\sim 0.07 \%)$ over a typical 11 year solar cycle, the amplitude of this oscillation in the UV spectrum is much more substantial ( $\sim 6 \%)$ [Gray et al., 2010]. Both ozone concentration and absorption are particularly sensitive to changes in UV radiation, both increasing substantially during solar maxima [Gray et al., 2010]. Coupling between the upper and lower atmospheres means that solarinduced changes in stratospheric ozone increase tropospheric temperatures [Shindell et al., 1999], thereby limiting hurricane potential intensity [Elsner et al., 2010].

[33] Similar periodicities have also been noted for other hurricane-forcing mechanisms, notably the Atlantic SST Dipole. Analysis of tropical Atlantic SSTs [Chang et al., 1997; Enfield and Mayer, 1997; Houghton and Tourre, 1992] has identified a persistent temperature dipole across the ITCZ that oscillates on decadal timescales. This is thought to impact North Atlantic hurricane activity both directly through changes in SST and indirectly by modulating the West African Monsoon [Landsea et al., 1999; Xie et al., 2005]. Indeed, it is possible that several of the high frequency variations observed in our records, and likewise in late Holocene reconstructions of the West African Monsoon [Shanahan et al., 2009], arise from oscillations between modes of the Atlantic SST dipole. The Atlantic multi-decadal oscillation is also thought to control Atlantic SSTs and impact the West African Monsoon, as well as hurricane activity [Goldenberg et al., 2001; Knight et al., 2006; Zhang and Delworth, 2006] on short timescales. However, significant controversy has surrounded the role AMO has played in modulating hurricane activity over the past 150 years [Mann and Emanuel, 2006], and longer records are needed to resolve how these climate forcings behave on timescales stretching into the midHolocene. Moreover, separation of these climatic drivers in our reconstruction is limited by an average sampling interval of 4-5 years and therefore a Nyquist frequency approaching 0.1 . Therefore, increased efforts at generating high-resolution Holocene hurricane records are likely necessary to constrain what factors are influencing hurricane activity on such short timescales.

\section{Conclusions}

[34] Here, we developed a new proxy for reconstructing tropical cyclone frequency and used it to document substantial variability in North Atlantic hurricane activity in the Bahamas over the Holocene. Our results agree with previous studies which have emphasized the role of ENSO and the West African Monsoon in controlling late Holocene hurricane frequency and indicate that insolation may be important in the forcing mechanism of the North Atlantic storm intensity on millennial timescales. Indeed, the low frequency of storm events near the Bahamas during the mid-Holocene indicates that increased $\mathrm{NH}$ insolation and a related northward shift of the ITCZ may have worked to decrease major North Atlantic hurricane development. On shorter timescales ( $\sim 11$ years), we show that increases in solar radiation may 


\section{TOOMEY ET AL.: A 7000 YR RECORD OF HURRICANE ACTIVITY}

work to limit hurricane potential intensity by decreasing the ocean-atmosphere thermal gradient. However, a wider array of higher resolution records is needed to isolate this potential solar influence from other climate forcings (Atlantic Multidecadal Oscillation, Atlantic Dipole, ENSO, West African Monsoon) that are known to oscillate at similar frequencies. Here, we provide a blueprint for developing just such records. Ultimately, these methods provide an opportunity to use a large existing archive of carbonate bank cores (e.g., Eberli et al., 1997) to reconstruct North Atlantic hurricane activity into the Late Pleistocene and beyond.

[35] Acknowledgements. This research was supported by awards from the Division of Ocean Sciences and the Division of Atmospheric and Geospace Sciences of the National Science Foundation to William B. Curry and an NSERC Post-Doctoral Fellowship to Peter van Hengstum. We thank Andrew Solow, Delia Oppo, Maureen Conte, Andrew Ashton, Taylor Perron, and Jon Woodruff for their advice. Jean Lynch-Stieglitz shared some of her unpublished sedimentological and stratigraphic information for this project. We also thank Amy Frappier and an anonymous reviewer for their thoughtful comments.

\section{References}

Appleby, P. G., and F. Oldfield (1978), The calculation of lead-210 dates assuming a constant rate of supply of unsupported ${ }^{210} \mathrm{~Pb}$ to the sediment, CATENA, 5(1), 1-8.

Appleby, P. G., and F. Oldfieldz (1983), The assessment of ${ }^{210} \mathrm{~Pb}$ data from sites with varying sediment accumulation rates, Hydrobiologia, 103(1), 29-35.

Bell, G. D., and M. Chelliah (2006), Leading tropical modes associated with interannual and multidecadal fluctuations in North Atlantic Hurricane activity, J. Climate, 19(4), 590-612

Bernet, K. H., G. P. Eberli, and A. Gilli (2000), Turbidite frequency and composition in the distal part of the Bahamas Transect, Proc. Ocean Drill. Project, Sci. Results, 166, 45-60.

Burns, S. J., and A. C. Neumann (1987), Pelagic sedimentation on an inactive gullied slope, Northwest Providence Channel, Bahamas, Mar. Geol. $77(3-4), 277-286$.

Chang, G. C., T. D. Dickey, and A. J. Williams, III (2001), Sediment resuspension over a continental shelf during Hurricanes Edouard and Hortense, J. Geophys. Res., 106(C5), 9517-9531.

Chang, P., L. Ji, and H. Li (1997), A decadal climate variation in the tropical Atlantic Ocean from thermodynamic air-sea interactions, Nature, 385(6616) 516-518.

Chenoweth, M. (2006), A reassessment of historical Atlantic Basin tropical cyclone activity, $1700-1855$, Clim. Change, 76(1), 169-240.

Cohen, T. J., and E. I. Sweetser (1975), The 'spectra' of the solar cycle and of data for Atlantic tropical cyclones, Nature, 256(5515), 295-296.

deMenocal, P., J. Ortiz, T. Guilderson, and M. Sarnthein (2000), Coheren high- and low-latitude climate variability during the Holocene warm period, Science, 288(5474), 2198-2202.

Donnelly, J. P., and J. D. Woodruff (2007), Intense hurricane activity ove the past 5,000 years controlled by El Niño and the West African Monsoon, Nature, 447(7143), 465-468.

Donnelly, J. P., S. Roll, M. Wengren, J. Butler, R. Lederer, and T. Webb (2001), Sedimentary evidence of intense hurricane strikes from New Jersey, Geology, 29(7), 615-618.

Eberli, G. P., P. K. Swart, M. J. Malone, and e. al. (1997), Proc. ODP, Init. Repts., 166, Ocean Drilling Program, College Station, TX.

Elsner, J. B., and A. B. Kara (1999), Hurricanes of the North Atlantic, Oxford University Press, New York.

Elsner, J. B., T. H. Jagger, and R. E. Hodges (2010), Daily tropical cyclone intensity response to solar ultraviolet radiation, Geophys. Res. Lett., 37(9), L09701.

Emanuel, K. (2005), Increasing destructiveness of tropical cyclones over the past 30 years, Nature, 436(7051), 686-688

Enfield, D. B., and D. A. Mayer (1997), Tropical Atlantic sea surface temperature variability and its relation to El Niño-Southern Oscillation, J. Geophys. Res., 102

Frappier, A. B., D. Sahagian, S. J. Carpenter, L. A. González, and B. R. Frappier (2007), Stalagmite stable isotope record of recent tropical cyclone events, Geology, 35(2), 111-114.

Gäggeler, H., H. R. von Gunten, and U. Nyffeler (1976), Determination of ${ }^{210} \mathrm{~Pb}$ in lake sediments and in air samples by direct gamma-ray measurement, Earth Planet. Sci. Lett., 33(1), 119-121.
Goldenberg, S. B., and L. J. Shapiro (1996), Physical mechanisms for the association of El Niño and West African rainfall with Atlantic major hurricane activity, J. Climate, 9(6), 1169-1187.

Goldenberg, S. B., C. W. Landsea, A. M. Mestas-Nuñez, and W. M. Gray (2001), The recent increase in Atlantic Hurricane activity: causes and implications, Science, 293(5529), 474-479.

Grammer, G. M., and R. N. Ginsburg (1992), Highstand versus lowstand deposition on carbonate platform margins: insight from Quaternary foreslopes in the Bahamas, Mar. Geol., 103, 125-136.

Gray, L. J., et al. (2010), Solar influences on climate, Rev. Geophys., 48(4), RG4001.

Gray, W. M. (1984), Atlantic seasonal hurricane frequency. Part I: El Niño and $30 \mathrm{mb}$ quasi-biennial oscillation influences, Mon. Weather Rev., 112(9), 1649-1668.

Gray, W. M., and C. W. Landsea (1992), African rainfall as a precursor of hurricane-related destruction on the U.S. East Coast, Bull. Am. Meteorol. Soc., 73(9), 1352-1364.

Haug, G. H., K. A. Hughen, D. M. Sigman, L. C. Peterson, and U. Röhl (2001), Southward migration of the Intertropical Convergence Zone through the Holocene, Science, 293(5533), 1304-1308.

Hetzinger, S., M. Pfeiffer, W.C. Dullo, N. Keenlyside, M. Latif, and J. Zinke (2008), Caribbean coral tracks Atlantic Multidecadal Oscillation and past hurricane activity, Geology, 36(1), 11-14.

Hine, A. C., R. J. Wilber, J. M. Bane, A. C. Neumann, and K. R. Lorenson (1981), Offbank transport of carbonate sands along open, leeward bank margins: Northern Bahamas, Mar. Geol., 32, 327-348.

Houghton, R. W., and Y. M. Tourre (1992), Characteristics of low-frequency sea surface temperature fluctuations in the tropical Atlantic, J. Climate, 5(7), $765-772$.

Hubbard, D. K. (1992), Hurricane-induced sediment transport in open-shelf tropical systems: an example from St. Croix, U.S. Virgin Islands, J. Sediment. Res., 62(6), 946-960.

Kenter, J. A. M. (1990), Carbonate platform flanks: slope angle and sediment fabric, Sedimentology, 37(5), 777-794

Knapp, K. R., M. C. Kruk, D. H. Levinson, H. J. Diamond, and C. J. Neumann (2010), The International Best Track Archive for Climate Stewardship (IBTrACS), Bull. Am. Meteorol. Soc., 91(3), 363-376.

Knight, J. R., C. K. Folland, and A. A. Scaife (2006), Climate impacts of the Atlantic Multidecadal Oscillation, Geophys. Res. Lett., 33(17), L17706.

Korty, R. L., S. J. Camargo, and J. Galewsky (2012), Variations in tropical cyclone genesis factors in simulations of the Holocene epoch, J. Climate, 25(23), 8196-8211.

Landsea, C. W., R. A. Pielke, Jr., A. M. Mestas-Nunez, and J. A. Knaff (1999), Atlantic basin hurricanes: Indices of climatic changes, Clim Chang., 42(1), 89-129.

Lane, P., J. P. Donnelly, J. D. Woodruff, and A. D. Hawkes (2011), A decadally-resolved paleohurricane record archived in the late Holocene sediments of a Florida sinkhole, Mar. Geol., 287, 14-30.

Lawrence, J. R. (1998), Isotopic spikes from tropical cyclones in surface waters: Opportunities in hydrology and paleoclimatology, Chem. Geol. 144(1, Äi 2$), 153-160$.

Liu, K.-B., and M. L. Fearn (1993), Lake-sediment record of late Holocene hurricane activities from coastal Alabama, Geology, 21(9), 793-796.

Lockwood, M., and C. Fröhlich (2007), Recent oppositely directed trends in solar climate forcings and the global mean surface air temperature, Proc. R. Soc. A: Math. Phys. Eng. Sci., 463(2086), 2447-2460.

Lomb, N. R. (1976), Least-squares frequency analysis of unequally spaced data, Astrophys. Space Sci., 39(2), 447-462.

Lund, D. C., and W. Curry (2006), Florida Current surface temperature and salinity variability during the last millennium, Paleoceanography, 21(2), PA2009.

Lund, D. C., J. Lynch-Stieglitz, and W. B. Curry (2006), Gulf Stream density structure and transport during the past millennium, Nature, 444(7119), 601-604.

Lynch-Stieglitz, J., W. B. Curry, and D. C. Lund (2009), Florida Straits density structure and transport over the last 8000 years, Paleoceanography, 24(3), PA3209.

Lynch-Stieglitz, J., M. W. Schmidt, and W. B. Curry (2011), Evidence from the Florida Straits for Younger Dryas ocean circulation changes, Paleoceanography, 26(1), PA1205.

Makou, M. C., T. I. Eglinton, D. W. Oppo, and K. A. Hughen (2010), Postglacial changes in El Niño and La Niña behavior, Geology, 38(1), 43-46. Mann, M. E., and K. A. Emanuel (2006), Atlantic hurricane trends linked to climate change, Eos Trans. $A G U, 87(24)$.

Miller, D. L. C. I. Mora, H. D. Grissino-Mayer, C. J. Mock, M. E. Uhle, and Z. Sharp (2006), Tree-ring isotope records of tropical cyclone activity, Proc. Natl. Acad. Sci. U. S. A., 103(39), 14294-14297.

Moy, C. M., G. O. Seltzer, D. T. Rodbell, and D. M. Anderson (2002), Variability of El Niño/Southern Oscillation activity at millennial timescales during the Holocene epoch, Nature, 420(6912), 162-165. 


\section{TOOMEY ET AL.: A 7000 YR RECORD OF HURRICANE ACTIVITY}

Mulder, T., et al. (2012), New insights into the morphology and sedimentary processes along the western slope of Great Bahama Bank, Geology, 40(7), 603-606

Neumann, A. C., and L. S. Land (1975), Lime mud deposition and calcareou algae in the Bight of Abaco, Bahamas: A budget, J. Sedimen. Res., 45(4), 763-786.

Nguetsop, V. F. B., S. Servant-Vildary, and M. Servant (2004), Late Holocene climatic changes in West Africa, a high resolution diatom record from equatorial Cameroon, Quat. Sci. Rev., 23, 591-609.

Nott, J., and M. Hayne (2001), High frequency of 'super-cyclones' along the Great Barrier Reef over the past 5,000 years, Nature, 413(6855), $508-512$

Park, L. E. (2012), Comparing two long-term hurricane frequency and intensity records from San Salvador Island, Bahamas, J. Coastal Res., 28(4), 891-902.

Pilskaln, C. H., A. C. Neumann, and J. M. Bane (1989), Periplatform carbonate flux in the northern Bahamas, Deep Sea Res. Part A. Oceanographic Research Papers, 36(9), 1391-1406.

Rendle, R. H., and J. J. G. Reijmer (2002), Quaternary slope development of the western, leeward margin of the Great Bahama Bank, Mar. Geol., 185 , $143-164$

Roth, S., and J. J. G. Reijmer (2004), Holocene Atlantic climate variations deduced from carbonate periplatform sediments (leeward margin, Great Bahama Bank), Paleoceanography, 19(1), PA1003.

Ryan, W. B. F., et al. (2009), Global multi-resolution topography synthesis, Geochem. Geophys. Geosyst., 10(3), Q03014.

Scargle, J. D. (1982), Studies in astronomical time series analysis. II Statistical aspects of spectral analysis of unevenly spaced data, Astrophys. $J ., 263,835-853$.

Scheitlin, K., J. B. Elsner, J. Malmstadt, R. Hodges, and T. Jagger (2010), Toward increased utilization of historical hurricane chronologies, $J$ Geophys. Res., 15, D03108.
Schulz, M., and M. Mudelsee (2002), REDFIT: Estimating red-noise spectra directly from unevenly spaced paleoclimatic time series, Comput. Geosci., 28(3), 421-426.

Scileppi, E., and J. P. Donnelly (2007), Sedimentary evidence of hurricane strikes in western Long Island, New York, Geochem. Geophys. Geosyst., 8(6), Q06011.

Shanahan, T. M., J. T. Overpeck, K. J. Anchukaitis, J. W. Beck, J. E. Cole, D. L. Dettman, J. A. Peck, C. A. Scholz, and J. W. King (2009), Atlantic forcing of persistent drought in West Africa, Science, 324(5925), 377-380. Shindell, D., D. Rind, N. Balachandran, J. Lean, and P. Lonergan (1999), Solar cycle variability, ozone, and climate, Science, 284(5412), 305-308. van Hengstum, P. J., J. P. Donnelly, M. R. Toomey, N. A. Albury, and B. Kakuk (2013), An active interval of hurricane activity from 1350 to 1550 AD on the Little Bahama Bank, Cont. Shelf Res., submitted.

Weber, J., M. H. Conte, S. Huang, T. Dickey, and J. Acker (2006), Advection of detrital carbonate sediment to the deep ocean by passage of Hurricane Fabian over Bermuda, EOS Trans. Am. Geophys. Union, 87(36).

Webster, P. J., G. J. Holland, J. A. Curry, and H.-R. Chang (2005), Changes in tropical cyclone number, duration, and intensity in a warming environment, Science, 309(5742), 1844-1846.

Wilber, R. J., J. D. Milliman, and R. B. Halley (1990), Accumulation of bank-top sediment on the western slope of Great Bahama Bank: Rapid progradation of a carbonate megabank, Geology, 18(10), 970-974.

Wilson, P. A and H. H. Roberts (1995), Density cascading: Off-shelf sediment transport, evidence and implications, Bahama Banks, J. Sediment. Res., 65(1a), 45-56.

Xie, L., T. Yan, and L. Pietrafesa (2005), The effect of Atlantic sea surface temperature dipole mode on hurricanes: Implications for the 2004 Atlantic hurricane season, Geophys. Res. Lett., 32(3), L03701.

Zhang, R., and T. L. Delworth (2006), Impact of Atlantic multidecadal oscillations on India/Sahel rainfall and Atlantic hurricanes, Geophys. Res. Lett., 33(17), L17712. 


\section{APPENDIX A1}

Supplemental to: Toomey, M., A.D. Ashton and J.T. Perron (2013). Profiles of ocean island coral reefs controlled by sea-level history and carbonate accumulation rates, Geology, 41, 731-734, doi:10.1130/G34109.1.

GSA data repository: 2013204 

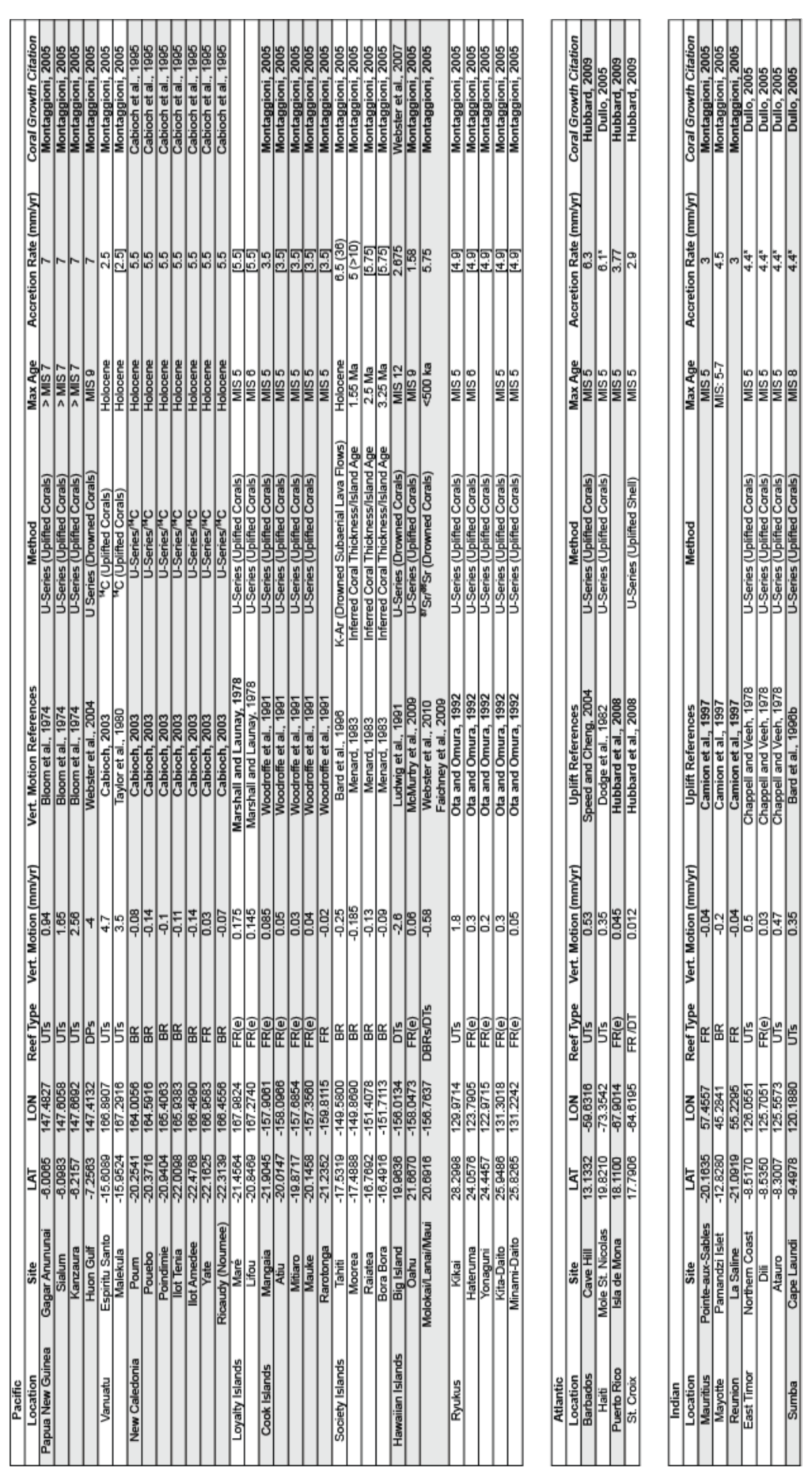

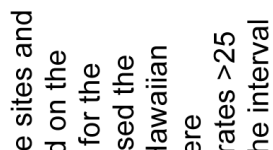

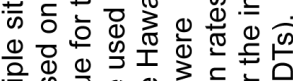

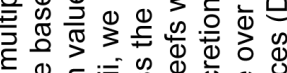

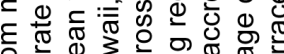

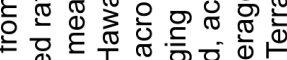

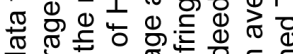

0 눙 $\frac{\pi}{2}$ 응

D

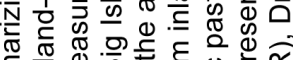

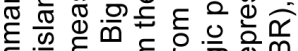

है일

कि क ष

o

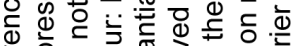

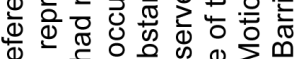

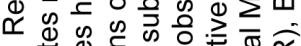
ஸे

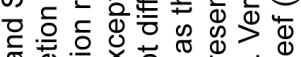
б

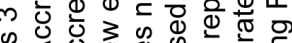

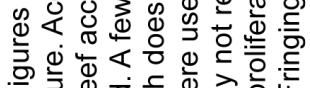
运言

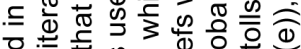
过

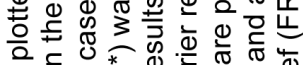
每.

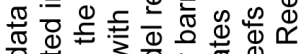

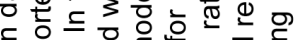

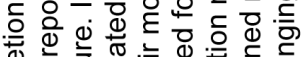
过 ब 중 車

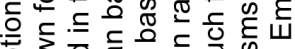

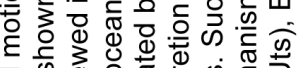

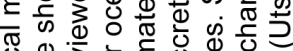

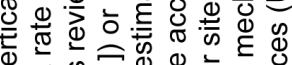

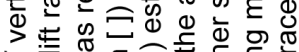
过

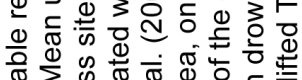

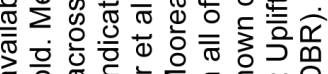

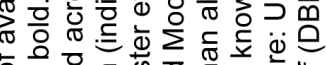

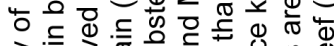

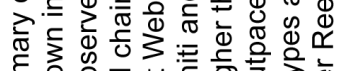

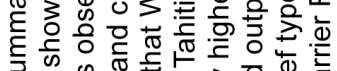

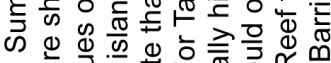

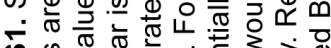
के 0

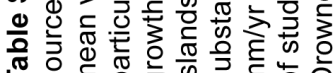




\section{Methods: Numerical Model}

The numerical model simulates reef profile evolution based on parameterizations of coral growth, wave erosion, on- and off-shore sediment transport by waves, sediment deposition by primary production in lagoons, and vertical motion. These processes operate over an initially linear profile (representing the flank of a volcanic island) as it experiences sea-level changes as well as spatially and temporally uniform uplift or subsidence. Figure S1 illustrates the model domain and the processes that shape the model reef. The rate of change of the surface profile height $z(x, t), x$ being horizontal distance and $t$ time, is given by the expression

$$
\frac{d z}{d t}=\frac{d r}{d t}+\frac{d s}{d t}+V
$$

where $\mathrm{r}$ is the reef thickness, $s$ is the sediment thickness, and $V$ is the vertical motion rate (subsidence or uplift) of the underlying bedrock surface. The primary control on profile evolution is the local water depth $(h)$,

$$
h=S(t)-z(x, t),
$$

where $S(t)$ is the local eustatic sea-level height, at time t. The reef can thicken due to coral accumulation, $G$, and can be thinned by wave erosion, $W$, both of which depend on water depth and position along the profile:

$$
\frac{d r}{d t}=G(h, x)-W(h, x) .
$$

The sediment thickness changes due to production of sediment by wave erosion, gradients in sediment transport, $q_{s}$ (on- or off-shore wave-driven flux and offshore slope failure), and, in established lagoons, in situ primary production of sediment, $P$,

$$
\frac{\partial s}{\partial t}=W(h, x)-\frac{\partial q_{s}}{\partial x}+P(h, x)
$$

In each model time step, $\mathrm{D} t$ ( $50 \mathrm{yr}$ for all model simulations presented here), these equations are solved explicitly using finite difference approximations across a discretized profile with spacing $\mathrm{D} x$ between nodes ( $50 \mathrm{~m}$ for all simulations presented here). The various processes represented by the terms in Equations S1-S4, which are illustrated in Figure S1, are described in greater detail below. 


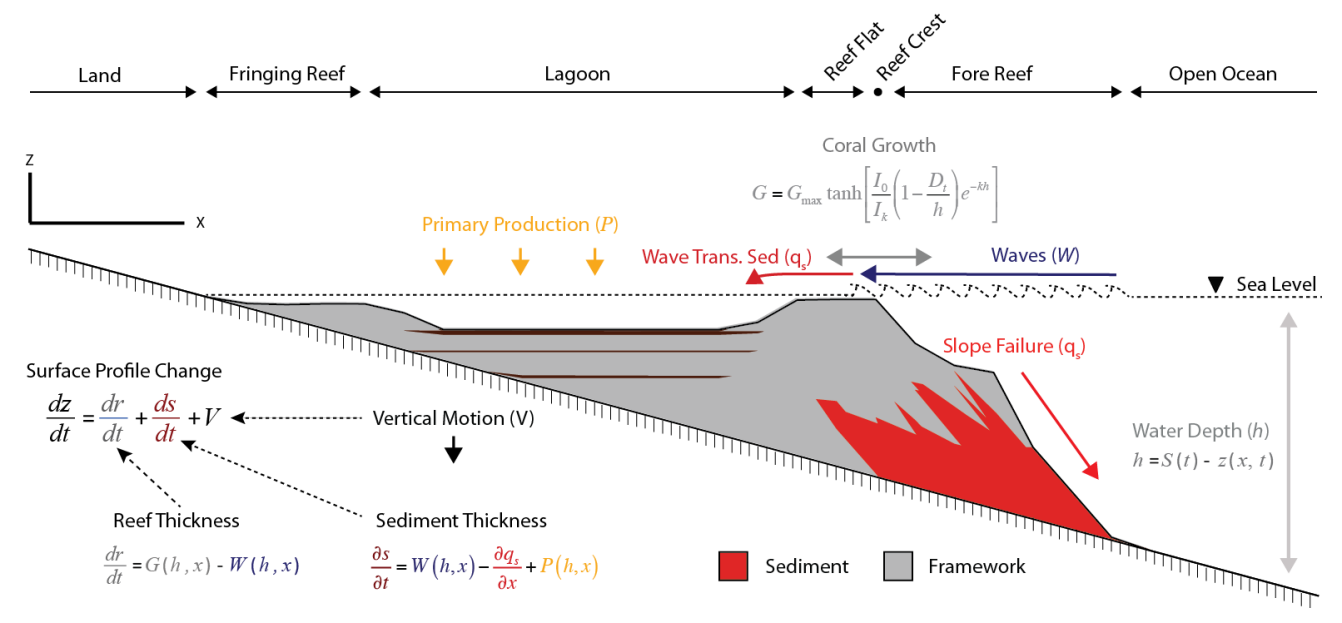

Figure S1. Model schematic showing reef process zones and equations governing changes in elevation along the profile. Gray and red shading represent coral framework and sediment, respectively. Hatched lower surface shows the initial profile.

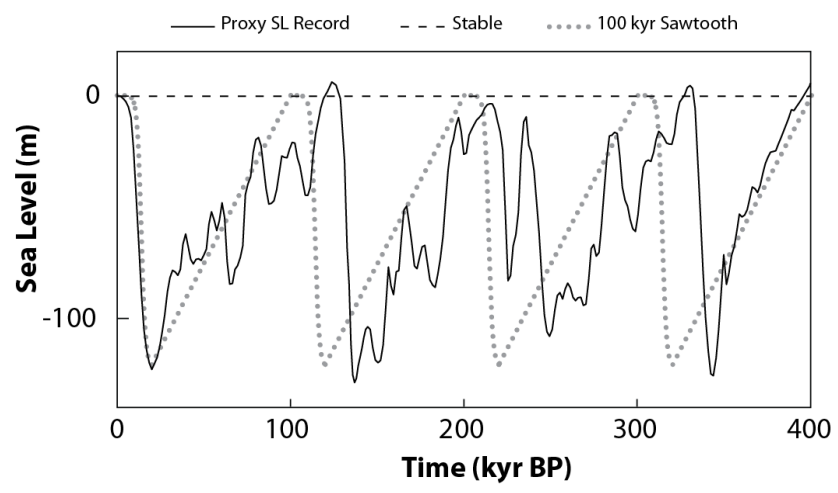

Figure S2. Sea-level histories used in model simulations. Shown are the isotope-derived sealevel curve (Waelbroeck et al., 2002) (black solid line), idealized saw-toothed sea-level curve (gray dotted line), and stable sea level (black dashed line). 


\subsection{Vertical Motion (Subsidence or Uplift)}

Vertical motion (subsidence or uplift) rate, $V(\mathrm{~mm} / \mathrm{yr}$ ), is held constant over the duration of each model run, and is assumed to be spatially uniform. Although crustal cooling, isostatic compensation, and dynamic topography can cause variation of vertical motion rates on longer timescales, observations indicate that vertical motion rates of volcanic islands remain relatively constant over the timescales we model (Watts and Zhong, 2000). We test a range of vertical motion rates between +5 and $-5 \mathrm{~mm} / \mathrm{yr}$, where positive values indicate uplift and negative values indicate subsidence.

\subsection{Reef Accretion (Coral Growth)}

Coral growth is dependent on several factors, including nutrient availability, turbidity, salinity, recruitment, light availability, and sediment removal (Montaggioni, 2005). In our model, we assume that light attenuation exerts a dominant control on vertical reef accretion rates, while dissipation of wave energy and sediment transport limit the width of the actively growing reef.

Vertical reef accretion at each point is calculated using a water-depth-dependent function (Fig. 2). Based on growth rates for Montastrea annularis, Bosscher and Schlager (Bosscher and Schlager, 1992) proposed an empirical formula linking skeletal extension rate (and therefore photosynthetic rate) to light intensity in the water column:

$$
\begin{gathered}
G=G_{\max } \tanh \left[\frac{I_{0}}{I_{k}}\left(1-\frac{D_{t}}{h}\right) e^{-k h}\right] \text { for } h \geq D_{t} \\
G=0 \text { for } h<D_{t}
\end{gathered}
$$

where $G_{\max }$ is the maximum accumulation rate ( $\left.\mathrm{mm} / \mathrm{yr}\right), I_{0}$ is the surface light intensity $\left(\mu \mathrm{Em}^{-2} \mathrm{~s}^{-1}\right), I_{k}$ is the saturating light intensity $\left(\mu \mathrm{Em}^{-2} \mathrm{~s}^{-1}\right)$, and $k$ is the light extinction coefficient $\left(\mathrm{m}^{-1}\right)$. Bosscher and Schlager (1992) use values of $I_{0} / I_{k}=4.444$ and $k=0.1$, based on observations from the Caribbean of Montastrea annularis growth relative to depth. The dependence of growth rate on the tidal depth, $D_{t}(\mathrm{~m})$, is a modification of the original model. This adjustment represents the slowing of reef accretion as it approaches sea level and is increasingly exposed at low tide. We assume a micro-tidal environment with a tidal depth of $0.5 \mathrm{~m}$.

We also assign a lateral dependence for the growth function as a proxy for wave exposure. Waves are important for removing sediment from the reef, with a lack of wave action creating marginal conditions for growth (Montaggioni, 2005). Based upon growth patterns of modern reefs, we set growth to zero starting $200 \mathrm{~m}$ shoreward of the reef crest (which is defined as the first point, moving shoreward from the ocean, at which $h \leq 2 \mathrm{~m}$ ). Bosence and Waltham (1990) apply a similar decay in growth starting from the reefocean boundary; their approach, however, assumes that growth decays linearly across the 
entire lagoon. Our assumption of a limited reef width is consistent with coral growth patterns and wave dissipation observed by Kench and Brander (2006) showing that wave energy rapidly decreases shoreward (100-500 $\mathrm{m})$ of the reef edge.

\subsection{Wave Erosion}

The development of wave-cut platforms on natural cliffed (Trenhaile, 2001) and abandoned reef coasts (Thompson et al., 2011) demonstrates that wave abrasion tends to be focused in the surf zone; we therefore compute wave erosion only in water depths shallower than $2 \mathrm{~m}$. In the horizontal direction, we implement wave erosion over the same width as the growth function based on the expectation that wave energy, and therefore erosive potential, is dissipated within a short distance of the reef crest (Kench and Brander, 2006). However, if the distance between the reef crest and the shoreline is less than the dissipation length used in the model, the backreef shoreline will also erode. Spencer (1985), working on Grand Cayman Island, found a range of wave erosion rates between $0.45 \mathrm{~mm} / \mathrm{yr}$ (wave-sheltered) and $2.77 \mathrm{~mm} / \mathrm{yr}$ (wave-exposed). For all runs, we use a wave erosion rate, $W$, of $2 \mathrm{~mm} / \mathrm{yr}$ of reef material. In general, wave erosion has a limited effect on model results, and mostly affects the preservation of slowly growing fringing reefs.

\subsection{Primary Production of Carbonate Sediment}

Primary production within the water column of the lagoon locally deposits carbonate sediment. Primary lagoon production, $P(x)$, occurs between the shoreline and the growing reef. In the model, sediment is produced through primary biotic activity at a constant rate across the entire lagoon; this volume then fills the deepest parts of the lagoon first. This pattern of deposition is consistent with seismic surveys of lagoon infill over the Holocene (Le Roy et al., 2008; Zinke et al., 2001). These studies demonstrate that channels and other depressions that formed during the previous glacial period have infilled with sediment over the Holocene, resulting in relatively flat-bottomed lagoons. Deposition continues until sediment is exhausted or all lagoonal accommodation space is filled. Based on observed sedimentation rates at Mayotte Lagoon far from the barrier reef or coastline (Zinke et al., 2001), we use a rate of $0.2 \mathrm{~mm} / \mathrm{yr}$ in the simulations presented here.

\subsection{Sediment Transport}

Detrital sediment in the model is created by wave abrasion of the reef crest, and is transported by waves and gravity. Wave erosion creates detritus that is either deposited offshore of the reef as talus or transported landward into the backreef lagoon (Fig. S1). In each time step, waves erode the reef between the reef crest $\left(x_{c}\right)$ and the landward limit of erosion $\left(x_{b}\right.$, typically $200 \mathrm{~m}$ from $\left.x_{c}\right)$, producing a volume of sediment $V_{w}$, 


$$
V_{w}=W \Delta t\left(x_{c}-x_{b}\right)
$$

When the reef crest is subaerially exposed, cutting off ocean circulation to the lagoon, this volume of eroded sediment is transported offshore to the fore-reef zone. In order to simulate talus accumulation on the fore-reef slope, we assume that sediment is transported by mass wasting events that form a talus slope with a fixed gradient of 0.3 . If the lagoon is open to the ocean, the eroded sediment is transported landward across the reef flat and into the lagoon. In the model, this sediment is deposited in the first node landward of the reef crest that is $>2 \mathrm{~m}$ in water depth. This depth $(2 \mathrm{~m})$ limit was implemented to represent the processes of sediment transport by shallow water waves across the reef flat, similar to that noted for tidal flats (Fagherazzi et al., 2006).

\subsection{Initial Conditions and Sea-Level Histories}

We begin parameter space simulations with a linear slope with a gradient of 0.15 , based on bathymetric profiles (GeoMapApp) across the flanks of real world islands. A sensitivity test over a range of different initial gradients indicates that slope does not greatly impact the type of gross reef morphology (i.e. barrier reef, uplifted terrace) produced by the model. Simulations were run under three different sea-level histories (Fig. S2): (1) stable sea level for a period of $400 \mathrm{kyr}$; (2) the proxy-derived record of Waelbroeck et al. (Waelbroeck et al., 2002) and (3) an idealized "saw-tooth" sea level curve with a period of $100 \mathrm{kyr}$, representing gradual sea level fall during the buildup of continental ice sheets and rapid sea level rise during deglaciations. Using several sealevel curves allows us to isolate the effects of large, $100 \mathrm{kyr}$ sea-level oscillations and smaller, second-order oscillations on reef morphology (Fig. S3). High-frequency, lowmagnitude oscillations in the proxy sea-level record may facilitate lagoon formation, but otherwise the distribution of reef types predicted by the model driven by the proxy record (Fig. 3B) is not significantly different than the distribution predicted with a generic sawtoothed sea-level curve (Fig. S3). This suggests that the approximately $100 \mathrm{kyr}$ glacial cycles of the late Pleistocene are the dominant sea-level control on modern reef morphology. Increasing appearance of barrier and fringing reefs with successive glacial cycles in the case of the saw-tooth driven runs (Fig S3 bottom) suggests that these features require long timescales to develop. 


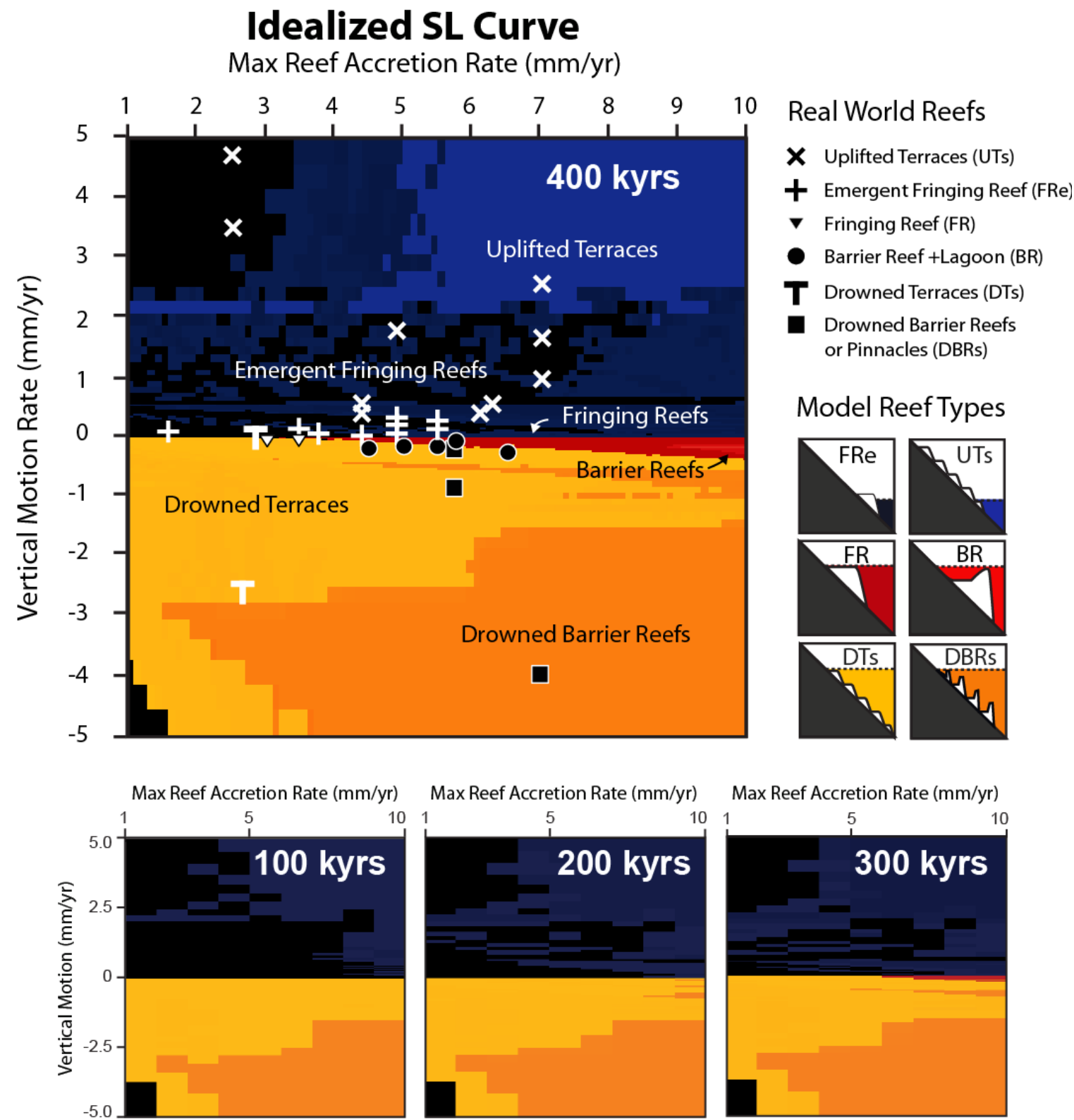

Figure S3: Regime diagram characterizing the morphology of reefs generated with a model driven by an idealized saw-toothed sea level curve (see Figure S2). (Top) Parameter space after 4 glacial cycles. Same plot after 1,2 and 3 glacial cycles is shown on bottom 


\section{Methods: Characterization of Reef Types}

\subsection{Characterizing Reefs from Model Output}

A set of simple rules is used to classify model profiles. In general, the algorithm searches for terraces wider than a prescribed width $(200 \mathrm{~m}$, the active growth width) with surface gradients gentler than a prescribed gradient $(0.1)$, or lagoons deeper than a given depth $(10 \mathrm{~m})$ below present-day sea level. We use present-day sea level as it allows for simple comparisons between model results and modern reefs.

Based on the depth at which a terrace or lagoon occurs, the procedure classifies the profile as one of six main reef types. Fringing reefs are defined as having a terrace $(>200$ $\mathrm{m}$ wide) between the reef crest (most oceanward node $<2 \mathrm{~m}$ water depth) and the shoreline with a gradient not exceeding 0.10 between adjacent profile locations. Similarly, drowned terraces are defined as terraces $(>200 \mathrm{~m}$ wide; $<0.10$ grade) occurring oceanward of the reef crest. Next, the model detects a barrier reef if the water depth at any location between the reef crest and the shoreline is greater than $10 \mathrm{~m}$. The model identifies drowned lagoons by starting at the reef crest and looking for $>10 \mathrm{~m}$ increases in relief moving in the oceanward direction. Finally, uplifted terraces are identified as subaerially exposed terraces $(>200 \mathrm{~m}$ wide; $<0.10$ grade).

Reef types are identified in the above order (fringing to uplifted terraces), with later types taking precedence, reflecting how an actively growing fringing reef is required to form a profile of uplifted and drowned terraces. As an example, most model profiles experiencing uplift produce both an active fringing reef at modern sea level and several uplifted (no longer growing) terraces at higher elevations. Given time, the active reef would become another uplifted terrace. In this case, the model prioritizes the uplifted terraces as the dominant morphology, as they characterize more completely the environmental conditions the reef has experienced over the model run.

\subsection{Characterizing Natural Reefs}

To allow us to compare our modeled reef types with bathymetric measurements, we compiled a database of reef vertical motion and maximum accretion rates reported in the literature (Table S1). In instances where an estimate of local accretion rate was not available, the rate from a nearby island was used and marked as such in Table S1. In general, the same criteria used in identifying model reef types were applied to the realworld reefs.

Classification of the morphology of natural reefs can be complicated, with various sites on an island exhibiting slightly different characteristics. Limited bathymetric coverage or poor spatial resolution in shallow water prevented application of the automated methodology we used to classify model profiles. We therefore used a procedure that 
seeks to classify the dominant reef morphology for a given island as one of six types using both objective and subjective criteria. Fringing and barrier reefs were classified based on satellite imagery, bathymetric surveys, and, when available, previous identification in the literature. A conservative approach was taken in identifying drowned barrier reefs or terraces. Their classification was limited to islands that had both the appropriate bathymetric geometry, and where dredging or diving had confirmed that this geometry was constructed from shallow-water corals. Identification of uplifted terraces or emergent fringing reefs also required observational confirmation. Because of uncertainties in relative sea level during marine isotope stage $5 \mathrm{e}$, which corresponds to the last interglacial highstand $(\sim 125 \mathrm{ka})$, sub-aerially exposed terraces between 0 and $6 \mathrm{~m}$ in elevation (Waelbroeck et al., 2002) were classified as fringing reefs.

Atolls and reefs on continental margins were not used for this comparison, as these systems are typically very old and likely bear the imprint of substantially different environmental conditions.

Table S2: Parameter inputs for parameter space (Fig.3, S3) model runs.

\begin{tabular}{|l|c|c|c|}
\hline Parameter & Name & Value & Units \\
\hline Duration & $\mathrm{T}$ & 400 & $\mathrm{kyrs}$ \\
Timestep & $\mathrm{dt}$ & 50 & $\mathrm{yrs}$ \\
Horizontal Spacing & $\mathrm{dx}$ & 50 & $\mathrm{~m}$ \\
Initial slope angle & $\mathrm{Grd}$ & 0.15 & $\%$ \\
Surface Light Intensity & $\mathrm{I}_{\mathrm{o}}$ & 2000 & $\mu \mathrm{Em}^{-2} \mathrm{~s}^{-1}$ \\
Saturating Light Intensity & $\mathrm{I}_{\mathrm{k}}$ & 450 & $\mu \mathrm{Em}^{-2} \mathrm{~s}^{-1}$ \\
Light Extinction Coef & $\mathrm{k}$ & 0.1 & {[]} \\
Tidal Range & $\mathrm{D}_{\mathrm{t}}$ & 0.5 & $\mathrm{~m}$ \\
Reef Crest Depth & $\mathrm{Rc}$ & 2 & $\mathrm{~m}$ \\
Reef Width & $\mathrm{Rw}$ & 200 & $\mathrm{~m}$ \\
Primary Production & $\mathrm{P}$ & 0.2 & $\mathrm{~mm} / \mathrm{yr}$ \\
Wave Erosion Rate & $\mathrm{W}$ & 2 & $\mathrm{~mm} / \mathrm{yr}$ \\
Talus Slope Angle & $\mathrm{Rs}$ & -0.3 & $\%$ \\
\hline
\end{tabular}

\section{References}

Bard, E., Hamelin, B., Arnold, M., Montaggioni, L., Cabioch, G., Faure, G., and Rougerie, F., 1996a, Deglacial sea-level record from Tahiti corals and the timing of global meltwater discharge: Nature, v. 382, no. 6588, p. 241-244.

Bard, E., Jouannic, C., Hamelin, B., Pirazzoli, P., Arnold, M., Faure, G., Sumosusastro, P., and Syaefudin, 1996b, Pleistocene sea levels and tectonic uplift based on dating of corals from Sumba Island, Indonesia: Geophys. Res. Lett., v. 23, no. 12, p. 14731476.

Bloom, A. L., Broecker, W. S., Chappell, J. M. A., Matthews, R. K., and Mesolella, K. J., 
1974, Quaternary sea level fluctuations on a tectonic coast: New $230 \mathrm{Th} / 234 \mathrm{U}$ dates from the Huon Peninsula, New Guinea: Quaternary Research, v. 4, no. 2, p. 185-205.

Bosence, D., and Waltham, D., 1990, Computer modeling the internal architecture of carbonate platforms: Geology, v. 18, no. 1, p. 26-30.

Bosscher, H., and Schlager, W., 1992, Computer simulation of reef growth: Sedimentology, v. 39, no. 3, p. 503-512.

Bosscher, H., and Southam, J., 1992, CARBPLAT, A computer model to simulate the development of carbonate platforms: Geology, v. 20, no. 3, p. 235-238.

Cabioch, G., 2003, Postglacial reef development in the South-West Pacific: case studies from New Caledonia and Vanuatu: Sedimentary Geology, v. 159, no. 1-2, p. 43-59.

Cabioch, G., Montaggioni, L. F., and Faure, G., 1995, Holocene initiation and development of New Caledonian fringing reefs, SW Pacific: Coral Reefs, v. 14, no. 3 , p. 131-140.

Camoin, G. F., Colonna, M., Montaggioni, L. F., Casanova, J., Faure, G., and Thomassin, B. A., 1997, Holocene sea level changes and reef development in the southwestern Indian Ocean: Coral Reefs, v. 16, no. 4, p. 247-259.

Dodge, R. E., Fairbanks, R. G., Benninger, L. K., and Maurrasse, F., 1983, Pleistocene Sea Levels from Raised Coral Reefs of Haiti: Science, v. 219, no. 4591, p. 1423-1425.

Dullo, W.-C., 2005, Coral growth and reef growth: a brief review: Facies, v. 51, no. 1, p. 33-48.

Fagherazzi, S., Carniello, L., D'Alpaos, L., and Defina, A., 2006, Critical bifurcation of shallow microtidal landforms in tidal flats and salt marshes: Proceedings of the National Academy of Sciences, v. 103, no. 22, p. 8337-8341.

Faichney, I. D. E., Webster, J. M., Clague, D. A., Kelley, C., Appelgate, B., and Moore, J. G., 2009, The morphology and distribution of submerged reefs in the Maui-Nui Complex, Hawaii: New insights into their evolution since the Early Pleistocene: Marine Geology, v. 265, no. 3-4, p. 130-145.

Hubbard, D. K., 2009, Depth-related and species-related patterns of Holocene reef accretion in the Caribbean and western Atlantic: a critical assessment of existing models: International Association of Sedimentologists: Spec. Publ. , v. 41, p. 1-18.

Hubbard, D. K., Burke, R. B., Gill, I. P., Ramirez, W. R., Sherman, C., Riegl, B. M., and 
Dodge, R. E., 2008, Coral-reef Geology: Puerto Rico and the US Virgin Islands Coral Reefs of the USA, Volume 1, Springer Netherlands, p. 263-302.

Kench, P. S., and Brander, R. W., 2006, Wave Processes on Coral Reef Flats: Implications for Reef Geomorphology Using Australian Case Studies: Journal of Coastal Research, p. 209-223.

Le Roy, P., Cabioch, G., Monod, B., Lagabrielle, Y., Pelletier, B., and Flamand, B., 2008, Late Quaternary history of the Nouméa lagoon (New Caledonia, South West Pacific) as depicted by seismic stratigraphy and multibeam bathymetry: A modern model of tropical rimmed shelf: Palaeogeography, Palaeoclimatology, Palaeoecology, v. 270, no. $1-2$, p. $29-45$.

Ludwig, K. R., Szabo, B. J., Moore, J. G., and Simmons, K. R., 1991, Crustal subsidence rate off Hawaii determined from 234U/238U ages of drowned coral reefs: Geology, v. 19, no. 2, p. 171-174.

Marshall, J. F., and Launay, J., 1978, Uplift rates of the Loyalty Islands as determined by $230 \mathrm{Th} / 234 \mathrm{U}$ dating of raised coral terraces: Quaternary Research, v. 9, no. 2, p. 186-192.

McMurtry, G. M., Campbell, J. F., Fryer, G. J., and Fietzke, J., 2010, Uplift of Oahu, Hawaii, during the past 500 k.y. as recorded by elevated reef deposits: Geology, v. 38 , no. 1 , p. 27-30.

Menard, H. W., 1983, Insular Erosion, Isostasy, and Subsidence: Science, v. 220, no. 4600, p. 913-918.

Montaggioni, L. F., 2005, History of Indo-Pacific coral reef systems since the last glaciation: Development patterns and controlling factors: Earth-Science Reviews, v. 71, no. 1-2, p. 1-75.

Ota, Y., and Omura, A., 1992, Contrasting styles and rates of tectonic uplift of coral reef terraces in the Ryukyu and Daito Islands, southwestern Japan: Quaternary International, v. 15/16, p. 17-29.

Paulay, G., and McEdward, L. R., 1990, A simulation model of island reef morphology: the effects of sea level fluctuations, growth, subsidence and erosion: Coral Reefs, v. 9, no. 2, p. 51-62.

Speed, R. C., and Cheng, H., 2004, Evolution of marine terraces and sea level in the last interglacial, Cave Hill, Barbados: Geological Society of America Bulletin, v. 116, no. 1-2, p. 219-232. 
Spencer, T., 1985, Marine erosion rates and coastal morphology of reef limestones on Grand Cayman Island, West Indies: Coral Reefs, v. 4, no. 2, p. 59-70.

Taylor, F. W., Isacks, B. L., Jouannic, C., Bloom, A. L., and Dubois, J., 1980, Coseismic and Quaternary Vertical Tectonic Movements, Santo and Malekula Islands, New Hebrides Island Arc: J. Geophys. Res., v. 85, no. B10, p. 5367-5381.

Thompson, W. G., Allen Curran, H., Wilson, M. A., and White, B., 2011, Sea-level oscillations during the last interglacial highstand recorded by Bahamas corals: Nature Geosci, v. 4, no. 10, p. 684-687.

Trenhaile, A. S., 2001, Modeling the effect of late Quaternary interglacial sea levels on wave-cut shore platforms: Marine Geology, v. 172, no. 3-4, p. 205-223.

Waelbroeck, C., Labeyrie, L., Michel, E., Duplessy, J. C., McManus, J. F., Lambeck, K., Balbon, E., and Labracherie, M., 2002, Sea-level and deep water temperature changes derived from benthic foraminifera isotopic records: Quaternary Science Reviews, v. 21, no. 1-3, p. 295-305.

Watts, A. B., and Zhong, S., 2000, Observations of flexure and the rheology of oceanic lithosphere: Geophysical Journal International, v. 142, no. 3, p. 855-875.

Webster, J. M., Clague, D. A., Faichney, I. D. E., Fullagar, P. D., Hein, J. R., Moore, J. G., and Paull, C. K., 2010, Early Pleistocene origin of reefs around Lanai, Hawaii: Earth and Planetary Science Letters, v. 290, no. 3-4, p. 331-339.

Webster, J. M., Wallace, L., Silver, E., Applegate, B., Potts, D., Braga, J. C., RikerColeman, K., and Gallup, C., 2004, Drowned carbonate platforms in the Huon Gulf, Papua New Guinea: Geochem. Geophys. Geosyst., v. 5, no. 11, p. Q11008.

Webster, J. M., Wallace, L. M., Clague, D. A., and Braga, J. C., 2007, Numerical modeling of the growth and drowning of Hawaiian coral reefs during the last two glacial cycles (0-250 kyr): Geochem. Geophys. Geosyst., v. 8, no. 3, p. Q03011.

Woodroffe, C. D., Short, S. A., Stoddart, D. R., Spencer, T., and Harmon, R. S., 1991, Stratigraphy and chronology of late pleistocene reefs in the Southern Cook Islands, south Pacific: Quaternary Research, v. 35, no. 2, p. 246-263.

Zinke, J., Reijmer, J. J. G., and Thomassin, B. A., 2001, Seismic architecture and sediment distribution within the Holocene barrier reef lagoon complex of Mayotte (Comoro archipelago, SW Indian Ocean): Palaeogeography, Palaeoclimatology, Palaeoecology, v. 175 , no. 1-4, p. 343-368.

APPENDIX A2 


\section{Field Work}

TAH VC10 along with high-resolution seismic profiles (FIG 1D) were collected aboard the S.S.V. Robert C. Seamans between in January of 2009. Core TAH VC10 was taken in Apu Bay $\left(16.6686^{\circ} \mathrm{S}, 151.4918^{\circ} \mathrm{W}\right)$ using a Rossfelder P-3 vibracoring system. Following recovery, it was sectioned, shipped to WHOI and refrigerated.

\section{X-Ray Fluorescence}

Relative elemental abundance measurements were made using an ITRAX X-ray fluorescence (XRF) corescanners at WHOI and UMASS Amherst. Because of disturbance to the tops of two sections (1:3 and 2:3) during shipment, intact areas of the core were sub-sampled using u-channels and scanned separately. Scanned coretops were lined up with main sections based on overlap. The ratio between $\mathrm{Ti} / \mathrm{Ca}$ was used in part to limit the effects of machine error (e.g. differences in tube strength) and changes in lithology (e.g. grain-size, water content, porosity) on XRF measurements. Background levels of $\mathrm{Ti} / \mathrm{Ca}$ appear relatively consistent between adjacent and overlapping core sections and no further corrections were made.

\section{Optical Spectrometry}

Color and mineral properties of the core were measured using optical reflectance spectrometry. Cores were scanned using a Geotek at $5 \mathrm{~mm}$ resolution between for wavelengths between $360-740 \mathrm{~nm}$. We then extracted the primary mineral constituents from this data using the following steps: (1) following with previously published methods (Ji et al., 2005), we computed the first derivative values, (2) derived the principal components and (3) compared them to the spectral profiles of known minerals (http://speclab.cr.usgs.gov/spectral-lib.html). The core-tops $(\sim 5 \mathrm{~cm})$ of sections 1 and 2, 
which were thought to have been disturbed (see above), were not included in this analysis.

\section{Grain-size}

Grain-size was measured using standard $63 \mu \mathrm{m}, 250 \mu \mathrm{m}$ and $2 \mathrm{~mm}$ sieves. First sediment was extracted from the core at $1 \mathrm{~cm}$ intervals before being dried at $100^{\circ} \mathrm{C}$ for 5 hours. After the dry mass was obtained, each sample was wet sieved at $63 \mu \mathrm{m}$. The $>63 \mu \mathrm{m}$ was then dried and subsequently dry sieved at $250 \mu \mathrm{m}$ and $2 \mathrm{~mm}$.

\section{Chronology}

Age control in the cores was established using ${ }^{210} \mathrm{~Pb}$ and radiocarbon dating (Table 1).

${ }^{210} \mathrm{~Pb}$ chronology was calculated as follows: (1) bulk material was extracted from the cores, (2) samples were crushed and homogenized, and (3) ${ }^{210} \mathrm{~Pb}$ activity was measured using gamma spectroscopy. We then iteratively (10000 times) re-sampled the probability distribution for the supported ${ }^{210} \mathrm{~Pb}$ levels $(\sim 24-30 \mathrm{~cm}$, FIG S1A, light grey) and the error on points with excess ${ }^{210} \mathrm{~Pb}(\sim 5-25 \mathrm{~cm}$, FIG S1A, black) before finding the best linear fit to our ${ }^{210} \mathrm{~Pb}$ curve. This produced a distribution of possible sedimentations rates (FIG S1B) which we then used to generate time-series for our runoff record from Tahaa that could be compared (Spearman correlation) to instrumental records (FIG S1C, SOI (NCAR-CGD) and Tahiti Rainfall (KNMI).

Conventional and continuous flow (von Reden et al., 2012) AMS radiocarbon dating of bulk samples were used to develop a long-term chronology for TAH VC10. Measurements were made at the National Ocean Sciences Accelerator Mass Spectrometry (NOSAMS) facility in Woods Hole, Massachusetts. Comparison between proximal ${ }^{14} \mathrm{C}(25-26 \mathrm{~cm})$ and ${ }^{210} \mathrm{~Pb}(23-24 \mathrm{~cm})$ dates indicates a systematic offset in the radiocarbon chronology, likely due to the reworking of old material from nearby relic 
fringing reefs, inferred based on apparent dissolution features. In order to account for this effect we developed a set of tools in Matlab to test a range of values for delta R: (1) Bulk carbonate and organic dates were separately assigned delta $\mathrm{R}$ values (2) probability distributions of R-corrected dates were calibrated following the procedures outlined for Calib 6.0. Bulk carbonate dates were calibrated using Marine09. Bulk organic dates were calibrated using IntCal09 under the assumption that this material either originates from the surrounding hillslopes or from primary productivity in lagoon, which is well mixed. (3) The resulting probability distributions were then used to iteratively (10000 times) generate time-index points which were then fit using a linear slope (originating at the end of the ${ }^{210} \mathrm{~Pb}$ chronology). The resulting field of r-squared values was then used to pick an appropriate value for delta $\mathrm{R}$ ( 1150 ; $\mathrm{r}$-squared $=0.96$; Sed-Rate $=1.6 \mathrm{~mm} / \mathrm{yr})$. This is

consistent with the mean sedimentation rate from our ${ }^{210} \mathrm{~Pb}$ chronology $(2.1 \mathrm{~mm} / \mathrm{yr})$ given the anticipated effects digenesis and compaction deeper in the sediment column. Given this chronology we also find a steady increase in the sand fraction since $\sim 1500 \mathrm{yrs} B P$ consistent with the end of the Mid Holocene Highstand in French Polynesia (Pirazzoli and Montaggioni, 1988) and similar observations elsewhere on Tahaa (Toomey et al., 2013).

\section{References:}

Ji, J., Shen, J., Balsam, W., Chen, J., Liu, L., Liu, X., 2005. Asian monsoon oscillations in the northeastern Qinghai-Tibet Plateau since the late glacial as interpreted from visible reflectance of Qinghai Lake sediments. Earth and Planetary Science Letters 233, 61-70.

Pirazzoli, P., Montaggioni, L., 1988. Holocene sea-level changes in French Polynesia. Palaeogeography, Palaeoclimatology, Palaeoecology 68, 153-175. 
Toomey, M.R., Donnelly, J.P., Woodruff, J.D., 2013. Reconstructing mid-late Holocene cyclone variability in the Central Pacific using sedimentary records from Tahaa, French Polynesia. Quaternary Science Reviews 77, 181-189.

von Reden, K.F., Roberts, M.L., Burton, J.R., Beaupre, S.R., 2012. Optimizing a microwave gas ion source for continuous-flow accelerator mass spectrometry. Review of Scientific Instruments 83, 02B304-304.
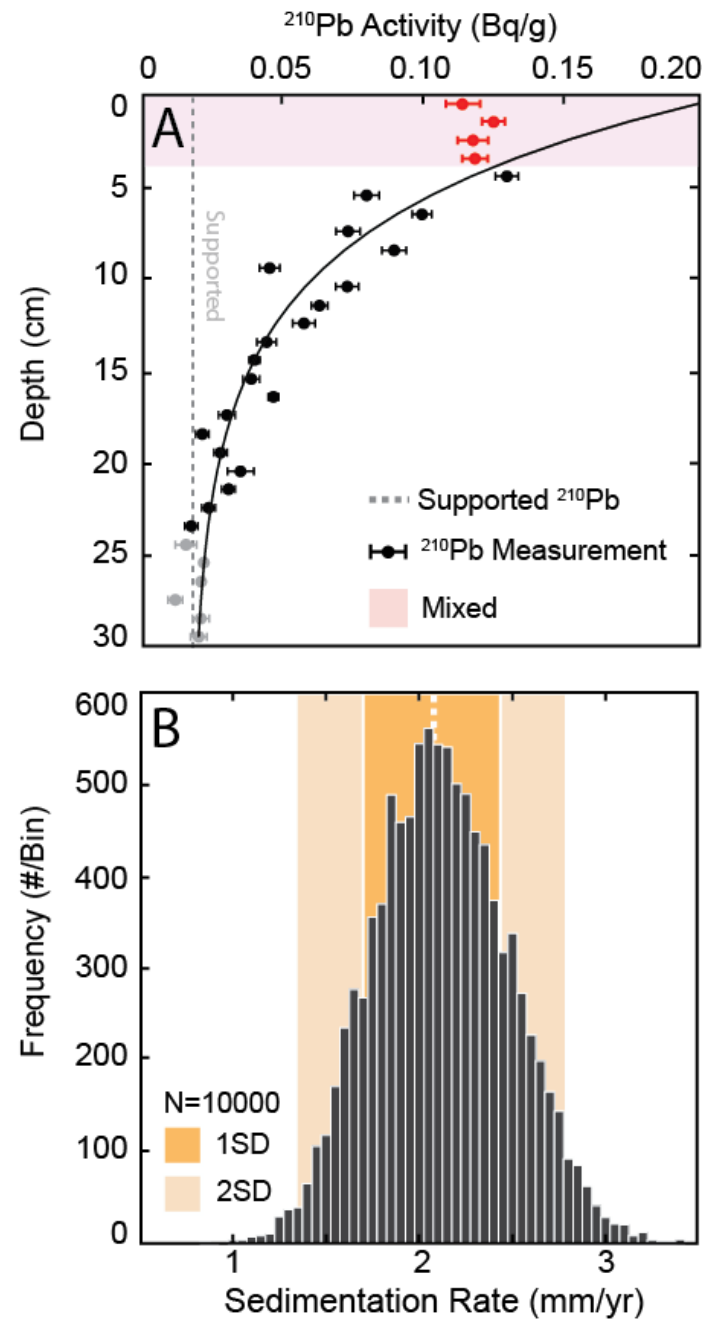
Figure $\mathrm{S} 1 .{ }^{210} \mathrm{~Pb}$ chronology for TAH VC10. (A) Top gives ${ }^{210} \mathrm{~Pb}$ profile for upper $30 \mathrm{~cm}$ of TAH VC10. Circles and error bars show the measured ${ }^{210} \mathrm{~Pb}$ activity and 1-sigma error range. Solid grey line the ${ }^{210} \mathrm{~Pb}$ curve given the median probable sedimentation. Red circles (shaded red area) are likely mixed and were not used in calculating our age model. Grey dotted line indicates level of supported ${ }^{210} \mathrm{~Pb}$ in the sediments. (B) Histogram of probable sedimentation rates generated by resampling the uncertainty on ${ }^{210} \mathrm{~Pb}$ measurements 10000 times. 1-Sigma range shaded dark orange. 2-sigma range shaded light orange. 

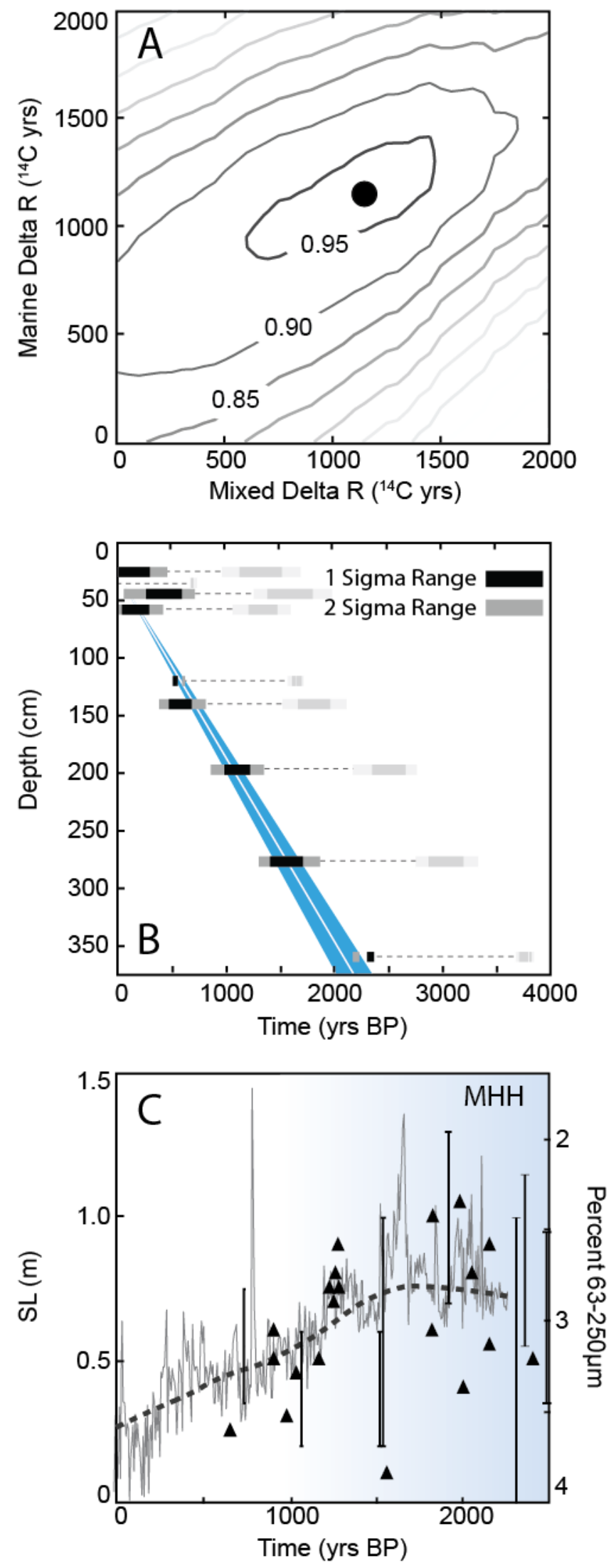
Figure S2. ${ }^{14} \mathrm{C}$ chronology for TAH VC10. (A) Mean linear fit $\left(\mathrm{r}^{2}\right)$ to calibrated ${ }^{14} \mathrm{C}$ ages using different values of $\Delta \mathrm{R}$. (B) Chronology using best-fit $\Delta \mathrm{R}$ (1150). Dark grey bars indicate 1-sigma range for radiocarbon dates. Light grey bars show 2-sigma range. Lightest grey bars show calibrated dates using standard correction. Blue shaded area gives 1-sigma range for linear fit. (C) Comparison of grain-size fraction $(63-250 \mu \mathrm{m}$; grey line; axis reversed), likely reflecting changes ins SL (Toomey et al., 2013), versus coral sea level index points (triangles) from French Polynesia (Pirazzoli and Montaggioni, 1988). 

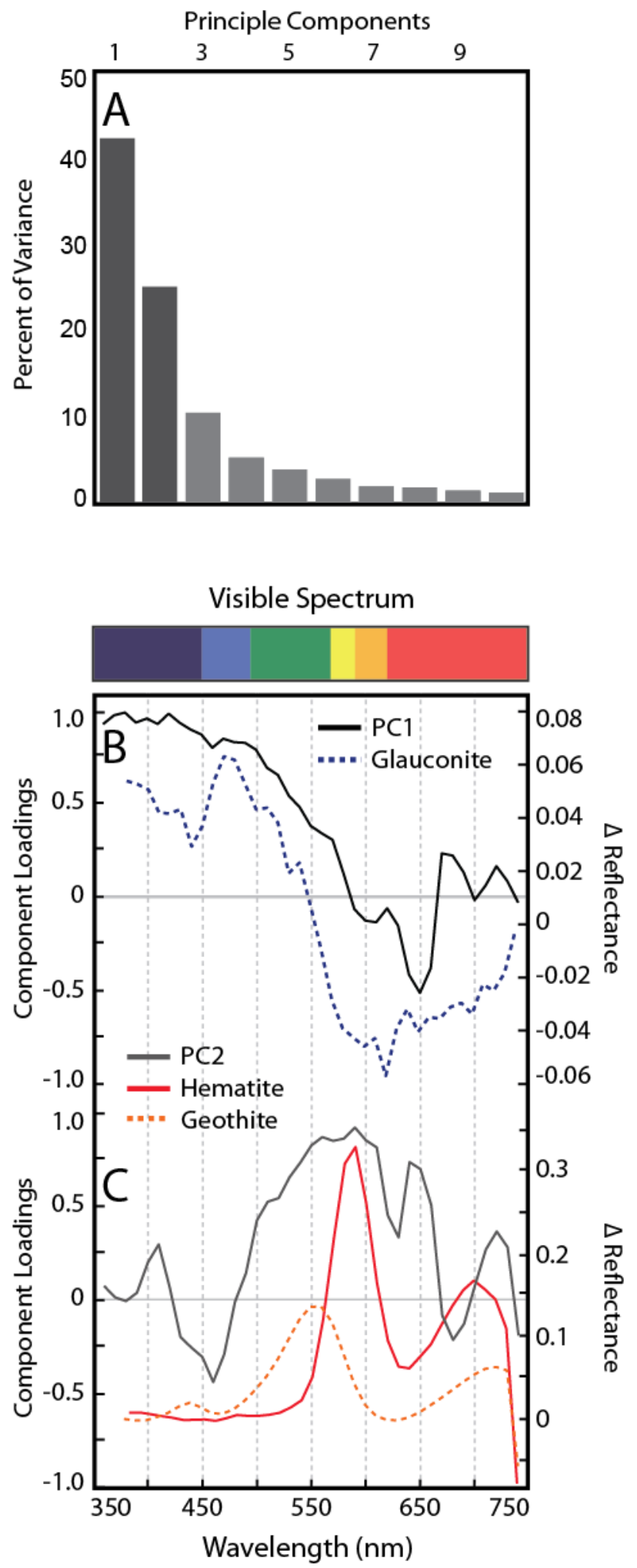
Figure S3. Principal component analysis of optical spectrophotometry data for TAH VC10. (Top) Scree plot showing the percent of variance accounted for by each principal component. First two principal components are marked by dark grey bars.

Table S1. Radiocarbon dates for core TAH VC10.

\begin{tabular}{|c|c|c|c|c|c|}
\hline $\begin{array}{l}\text { Depth } \\
\text { (cm) }\end{array}$ & $\begin{array}{l}{ }^{14} \mathrm{C} \\
\text { Age }\end{array}$ & Error & Material & Method & $\begin{array}{l}\delta^{13} \mathrm{C} \\
\left({ }^{\circ} / 00\right)\end{array}$ \\
\hline $25-26$ & 1753 & 172 & Bulk Carb & Gas Bench & \\
\hline $34-35$ & 750 & 25 & Bulk Org C & Conventional AMS & -16.92 \\
\hline $44-45$ & 2022 & 171 & Bulk Carb & Gas Bench & \\
\hline $59-60$ & 1770 & 122 & Bulk Carb & Gas Bench & \\
\hline $119-120$ & 1730 & 25 & Bulk Org C & Conventional AMS & -17.72 \\
\hline $139-140$ & 2207 & 122 & Bulk Carb & Gas Bench & \\
\hline $197-198$ & 2762 & 124 & Bulk Carb & Gas Bench & \\
\hline $277-278$ & 3212 & 124 & Bulk Carb & Gas Bench & \\
\hline $360-361$ & 3500 & 30 & Bulk Org C & Conventional AMS & -17.13 \\
\hline
\end{tabular}

Table S2. Locations of samples used in FIG 2C.

\begin{tabular}{ccc}
\hline Site & Latitude (dd) & Longitude (dd) \\
\hline Terrestrial 1 & -16.64636 & -151.53534 \\
Terrestrial 2 & -16.64458 & -151.52835 \\
Terrestrial 3 & -16.64421 & -151.52583 \\
Terrestrial 4 & -16.64042 & -151.51746 \\
Terrestrial 5 & -16.63792 & -151.51195 \\
Terrestrial 6 & -16.63662 & -151.50833 \\
Terrestrial 7 & -16.63200 & -151.50406 \\
Terrestrial 8 & -16.63219 & -151.50163 \\
Terrestrial 9 & -16.63462 & -151.50057 \\
Terrestrial 10 & -16.63475 & -151.49971 \\
Terrestrial 11 & -16.63447 & -151.49535 \\
Terrestrial 12 & -16.64522 & -151.49618
\end{tabular}




\begin{tabular}{ccc} 
Terrestrial 13 & -16.64192 & -151.49604 \\
Terrestrial 14 & -16.65106 & -151.49770 \\
Terrestrial 15 & -16.65865 & -151.49777 \\
Terrestrial 16 & -16.65353 & -151.48745 \\
Terrestrial 17 & -16.65494 & -151.48568 \\
Terrestrial 18 & -16.65632 & -151.48587 \\
Terrestrial 19 & -16.66669 & -151.48572 \\
Terrestrial 20 & -16.66781 & -151.48233 \\
\hline Reef Flat 1 & -16.71273 & -151.49278 \\
Reef Flat 2 & -16.71445 & -151.49960 \\
Reef Flat 3 & -16.71438 & -151.49973 \\
Reef Flat 4 & -16.71418 & -151.49915 \\
Reef Flat 5 & -16.71377 & -151.49823 \\
Reef Flat 6 & -16.71343 & -151.49690 \\
Reef Flat 7 & -16.71243 & -151.49533 \\
Reef Flat 8 & -16.71200 & -151.49405 \\
Reef Flat 9 & -16.71172 & -151.49283 \\
Reef Flat 10 & -16.71177 & -151.49265 \\
Reef Flat 11 & -16.71223 & -151.49212 \\
Reef Flat 12 & -16.71257 & -151.49108 \\
Reef Flat 13 & -16.71243 & -151.48985 \\
\hline
\end{tabular}

